\title{
U.S. Geological Survey Sage-Grouse and Sagebrush Ecosystem Research Annual Report for 2018
}
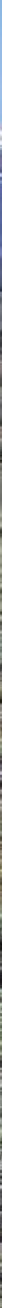

Circular 1446

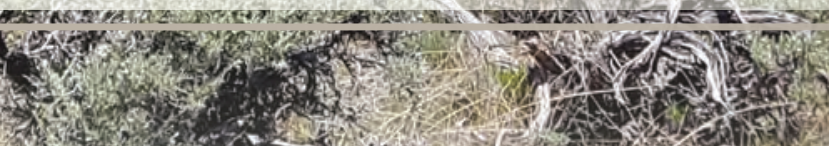

2)

in 1 (1)

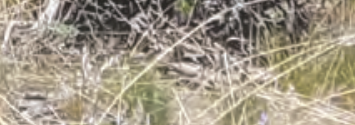
U.S. Department of the Interior
U.S. Geological Survey 
Cover. Sagebrush west of the Wind River Range in Wyoming. Photograph by Steven Hanser, U.S. Geological Survey. 


\section{U.S. Geological Survey Sage-Grouse and Sagebrush Ecosystem Research Annual Report for 2018}

Edited by Steven E. Hanser

Sagebrush in the Great Basin. Photograph by Sasha Reed, U.S. Geological Survey.

Circular 1446

U.S. Department of the Interior

U.S. Geological Survey 


\section{U.S. Department of the Interior \\ RYAN K. ZINKE, Secretary}

\section{U.S. Geological Survey James F. Reilly II, Director}

\section{U.S. Geological Survey, Reston, Virginia: 2018}

For more information on the USGS - the Federal source for science about the Earth, its natural and living resources, natural hazards, and the environment-visit https://www.usgs.gov or call 1-888-ASK-USGS.

For an overview of USGS information products, including maps, imagery, and publications, visit https://store.usgs.gov.

Any use of trade, firm, or product names is for descriptive purposes only and does not imply endorsement by the U.S. Government.

Although this information product, for the most part, is in the public domain, it also may contain copyrighted materials as noted in the text. Permission to reproduce copyrighted items must be secured from the copyright owner.

Suggested citation:

Hanser, S.E., ed., 2018, U.S. Geological Survey sage-grouse and sagebrush ecosystem research annual report for 2018: U.S. Geological Survey Circular 1446, 67 p., https://doi.org/10.3133/cir1446.

ISSN 1067-084X (print)

ISSN 2330-5703 (online)

ISBN 978-1-4113-4526-9 


\section{Contents}

Research To Support the Management of Sage-Grouse and the Sagebrush Ecosystem ................1 Structure of the U.S. Geological Survey Sage-Grouse and Sagebrush Ecosystem

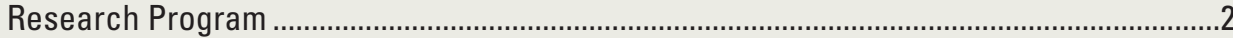

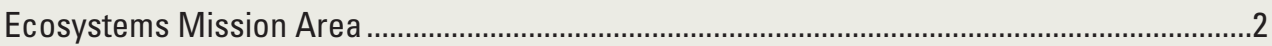

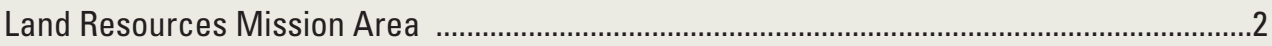

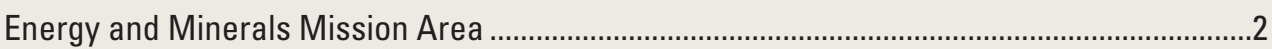

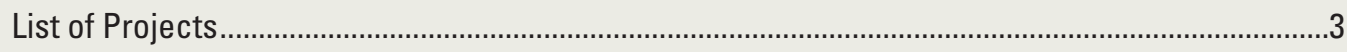

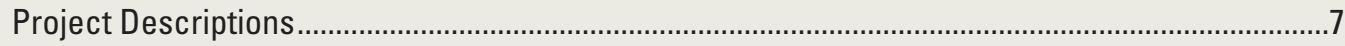

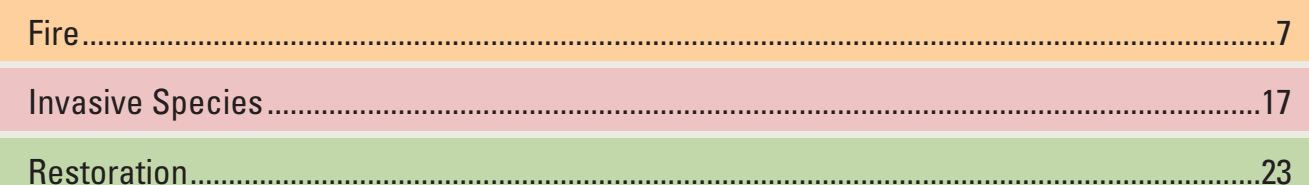

Sagebrush, Sage-Grouse, and Other Sagebrush-Associated Species...................................33

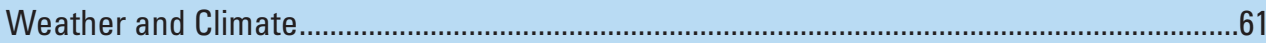

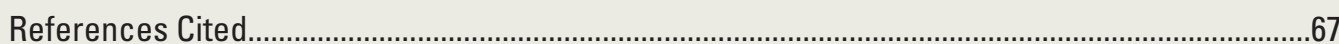

\section{Figures}

1. Location of the sagebrush ecosystem and distribution of greater and Gunnison sage-grouse in the Western United States.

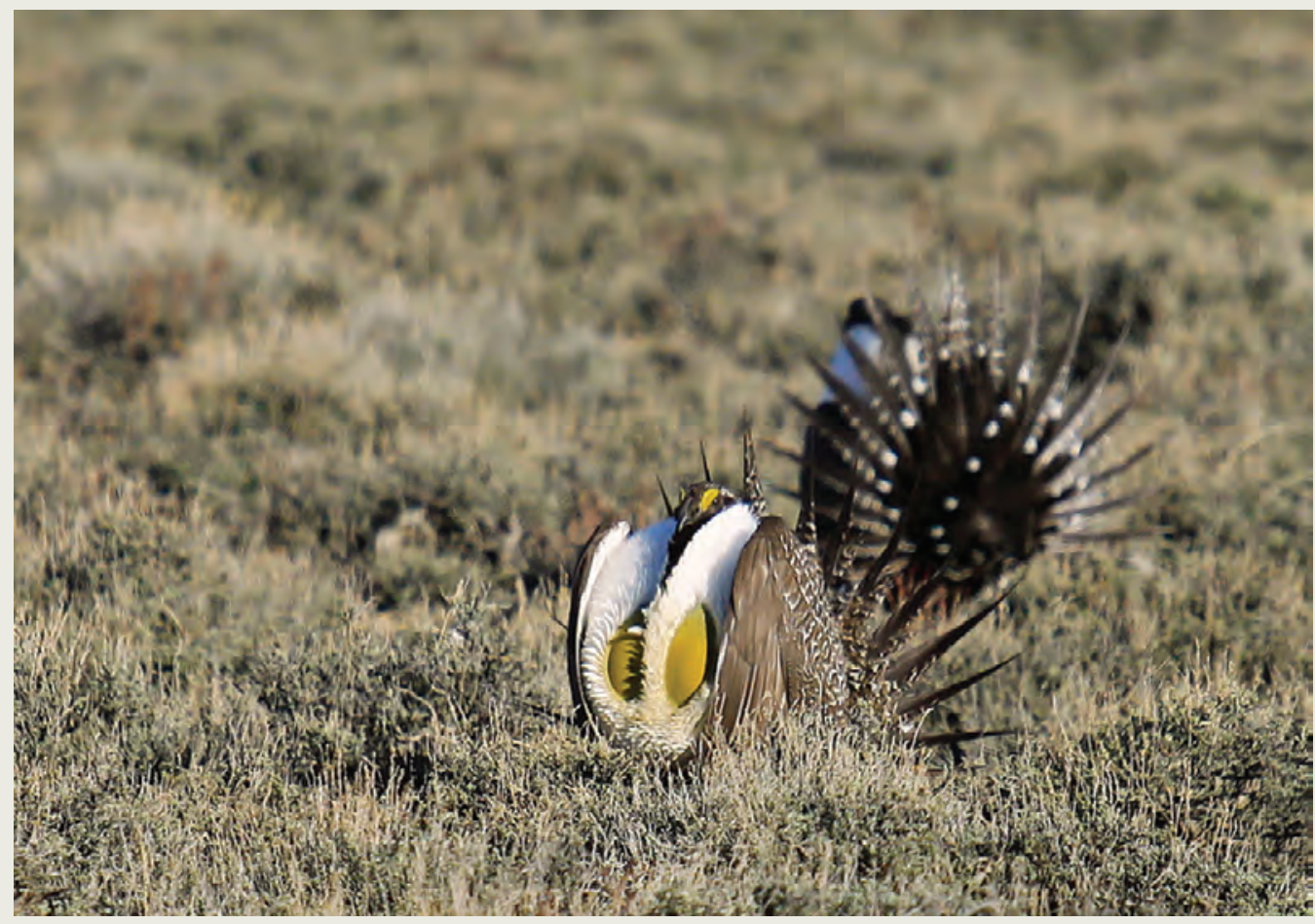

Greater sage-grouse displaying yellow air sacks. Photograph by Tatiana Gettelman, U.S. Geological Survey. 


\section{Conversion Factors}

U.S. customary units to International System of Units

\begin{tabular}{|c|c|c|}
\hline Multiply & By & To obtain \\
\hline \multicolumn{3}{|c|}{ Length } \\
\hline foot (ft) & 0.3048 & meter $(\mathrm{m})$ \\
\hline mile (mi) & 1.609 & kilometer (km) \\
\hline yard (yd) & 0.9144 & meter $(\mathrm{m})$ \\
\hline \multicolumn{3}{|c|}{ Area } \\
\hline acre & 4,047 & square meter $\left(\mathrm{m}^{2}\right)$ \\
\hline acre & 0.4047 & hectare (ha) \\
\hline acre & 0.4047 & square hectometer $\left(\mathrm{hm}^{2}\right)$ \\
\hline acre & 0.004047 & square kilometer $\left(\mathrm{km}^{2}\right)$ \\
\hline
\end{tabular}

International System of Units to U.S. customary units

\begin{tabular}{lcl}
\hline \multicolumn{1}{c}{ Multiply } & By & To obtain \\
\hline meter $(\mathrm{m})$ & Length & foot (ft) \\
kilometer $(\mathrm{km})$ & 3.281 & mile (mi) \\
meter $(\mathrm{m})$ & 0.6214 & yard (yd) \\
\hline square meter $\left(\mathrm{m}^{2}\right)$ & 1.094 & \\
hectare (ha) & Area & acre \\
square hectometer $\left(\mathrm{hm}^{2}\right)$ & 0.0002471 & acre \\
square kilometer $\left(\mathrm{km}^{2}\right)$ & 2.471 & acre \\
\hline
\end{tabular}

\section{Abbreviations}

\begin{tabular}{|c|c|c|c|}
\hline BLM & Bureau of Land Management & NGB & northern Great Basin \\
\hline CSU & Colorado State University & NRCS & Natural Resources Conservation \\
\hline DOI & U.S. Department of the Interior & & Service \\
\hline DRG & Disturbance Response Group & STM & state-and-transition model \\
\hline FIAT & Fire and Invasives Assessment Tool & USDA & U.S. Department of Agriculture \\
\hline FWS & U.S. Fish and Wildlife Service & USGS & U.S. Geological Survey \\
\hline GIS & geographic information system & VHF & very high frequency \\
\hline GPS & Global Positioning System & WLCI & $\begin{array}{l}\text { Wyoming Landscape Conservation } \\
\text { Initiative }\end{array}$ \\
\hline IPM & integrated population model & WSB & weed-suppressive bacteria \\
\hline LTDL & Land Treatment Digital Library & & \\
\hline & northern Columbia Basin & & \\
\hline
\end{tabular}




\title{
U.S. Geological Survey Sage-Grouse and Sagebrush Ecosystem Research Annual Report for 2018
}

\author{
Edited by Steven E. Hanser
}

\section{Research To Support the Management of Sage-Grouse and the Sagebrush Ecosystem}

The sagebrush (Artemisia spp.) ecosystem extends across a large portion of the Western United States, and the greater sage-grouse (Centrocercus urophasianus) is one of the iconic species of this ecosystem. Greater sage-grouse populations occur in 11 States and are dependent on relatively large expanses of sagebrush-dominated habitat (fig. 1). Sage-grouse populations have been experiencing long-term declines owing to multiple stressors, including interactions among fire, exotic plant invasions, and human land uses, which have resulted in significant loss, fragmentation, and degradation of landscapes once dominated by sagebrush. In addition to the sage-grouse, over 350 species of plants and animals are dependent on the sagebrush ecosystem.

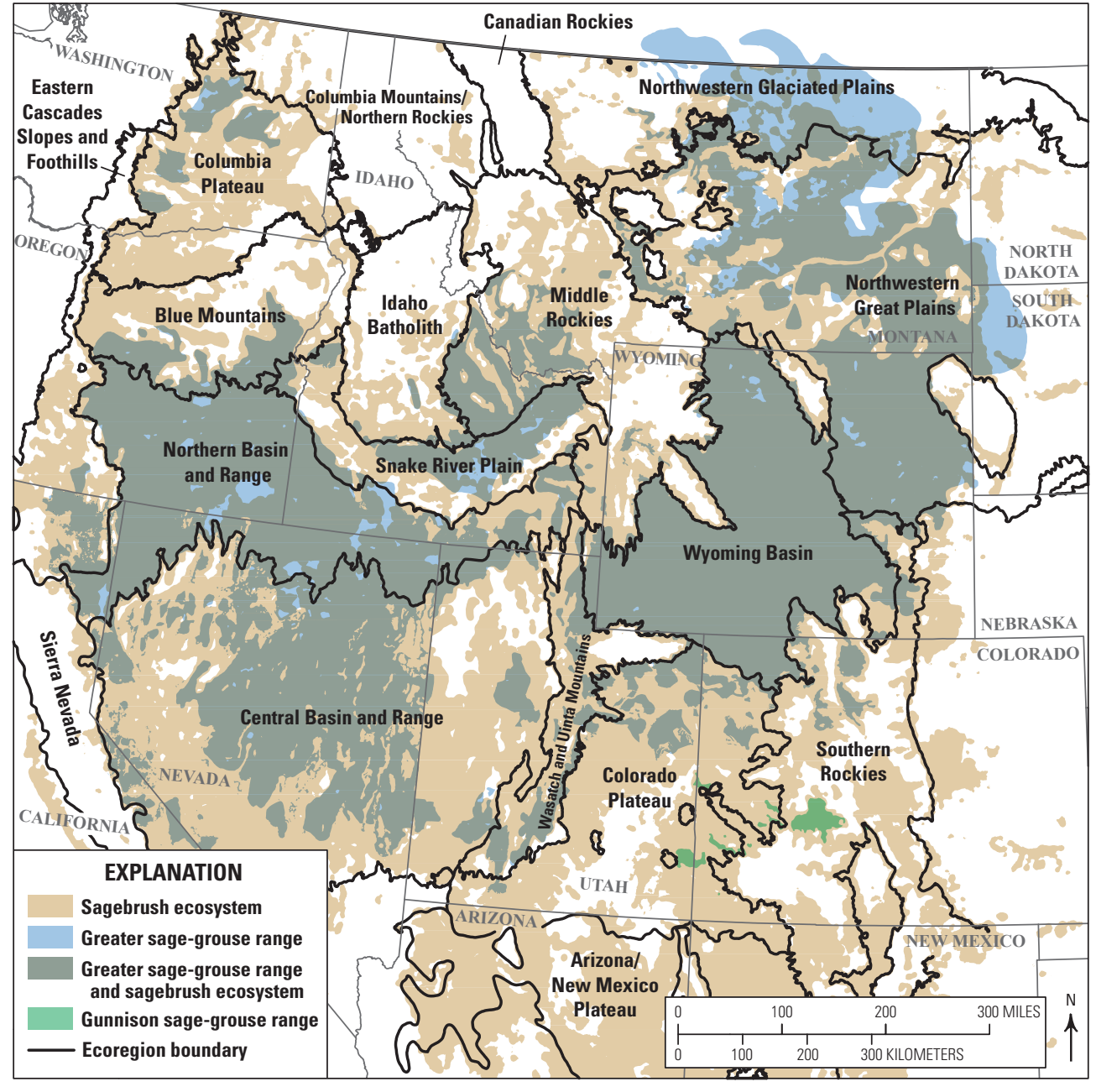

Figure 1. Location of the sagebrush ecosystem and distribution of greater and Gunnison sage-grouse in the Western United States. U.S. Environmental Protection Agency Level III ecoregions are labeled on the map. The Great Basin is composed of the Central Basin and Range, Northern Basin and Range, and Snake River Plain ecoregions. Modified from Integrated Rangeland Fire Management Strategy Actionable Science Plan Team (2016). 
Increasing knowledge about how these species and the sagebrush ecosystem respond to these stressors and to management actions can inform and improve strategies to maintain existing areas of intact sagebrush and restore degraded landscapes. The U.S. Geological Survey (USGS) has a broad research program focused on providing the science needed to inform these strategies and to help land and resource managers at the Federal, State, Tribal, and local levels as they work towards sustainable sagegrouse populations and restored landscapes for the broad range of uses critical to stakeholders in the Western United States.

USGS science has provided a foundation for major land and resource management decisions in the sagebrush ecosystem including actions that precluded the need to list the greater sage-grouse under the Endangered Species Act. The USGS continues to build on that foundation to inform science-based decisions within the U.S. Department of the Interior (DOI) and other Federal, State, and local agencies to help support local economies and the continued conservation, management, and restoration of the sagebrush ecosystem.

\section{Structure of the U.S. Geological Survey Sage-Grouse and Sagebrush Ecosystem Research Program}

This research program is led out of the USGS National Center, Ecosystems Mission Area with leadership and research scientists located in 10 western States in the following locations:

\section{Ecosystems Mission Area}

\section{National Center}

- Ecosystems Mission Area, Reston, Va.

\section{Science Centers}

- Forest and Rangeland Ecosystem Science Center, Corvallis, Oreg., and Boise, Idaho

- Fort Collins Science Center, Fort Collins, Colo.

- Northern Rocky Mountain Science Center, Bozeman, Mont.

- Southwest Biological Science Center, Flagstaff, Ariz., and Moab, Utah

- Western Ecological Research Center, Sacramento, Dixon, and Oakhurst, Calif.

\section{Cooperative Research Units}

- Colorado Cooperative Fish and Wildlife Research Unit, Fort Collins, Colo.

- Idaho Cooperative Fish and Wildlife Research Unit, Moscow, Idaho

- Oregon Cooperative Fish and Wildlife Research Unit, Corvallis, Oreg.

- Montana Cooperative Wildlife Research Unit, Missoula, Mont.

- Utah Cooperative Fish and Wildlife Research Unit, Salt Lake City, Utah

- Wyoming Cooperative Fish and Wildlife Research Unit, Laramie, Wyo.

\section{Land Resources Mission Area}

Science Centers

- Earth Resources Observation and Science Center, Sioux Falls, S. Dak., Boise, Idaho

- Geosciences and Environmental Change Science Center, Denver, Colo.

\section{Climate Adaptation Science Centers}

- North Central Climate Adaptation Science Center, Fort Collins, Colo.

- Northwest Climate Adaptation Science Center, Seattle, Wash.

- Southwest Climate Adaptation Science Center, Tucson, Ariz.

\section{Energy and Minerals Mission Area}

\section{Science Centers}

- Central Energy Resources Science Center, Denver, Colo.

- Science and Decisions Center, Denver, Colo. 


\section{List of Projects}

USGS sage-grouse and sagebrush ecosystem research is aligned with priority needs outlined in the "Integrated Rangeland Fire Management Strategy Actionable Science Plan" (Integrated Rangeland Fire Management Strategy Actionable Science Plan Team, 2016). Research projects are organized into five thematic areas: fire; invasive species; restoration; sagebrush, sage-grouse, and other sagebrush-associated species; and weather and climate. Project descriptions included in this report are organized according to these themes.

Fire..

Evaluating Effects and Effectiveness of Fuel Breaks

Assessing the Effectiveness of Fuel Breaks for Preserving Greater Sage-Grouse in the Great Basin.............................. 8

Evaluating Effects of Woody Fuels Treatments on Native and Nonnative Plants in the Sagebrush Biome......................... 9

Assessing the Proliferation, Connectivity, and Consequences of Invasive Fine Fuels ........................................................

Quantifying Fuels and the Effects of Reduction Treatments in Sagebrush Habitats............................................................... 10

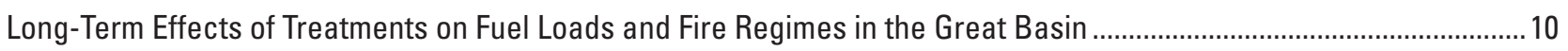

Future Fire in the Great Basin ................................................................................................................................... 11

Identifying the Effects of Reoccurring Fire on Sagebrush Ecosystems in the Northern Columbia Basin..........................12

Effects of Large-Scale Wildfire on Habitat Use and Demography of Female Greater Sage-Grouse in

Southeastern Oregon .............................................................................................................................. 12

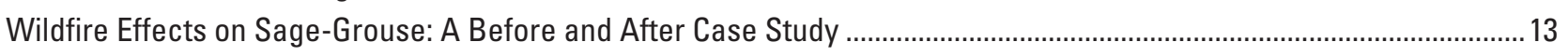

Response of Shrubland Birds to Prescribed-Fire and Mechanical Treatments .............................................................. 13

Effects of Wildfire and Climate on Persistence of Greater Sage-Grouse ........................................................................ 14

Perennial Grass Response to Postfire Grazing Management in the Great Basin .............................................................. 14

Vegetation Responses to Sagebrush-Reduction Treatments Measured by Satellites ......................................................... 14

Use of Sagebrush-Reduction Treatments by Mule Deer in Wyoming .......................................................................... 15

How Fire and Postfire Seeding Alter Pollinators in Sagebrush Habitat ......................................................................... 15

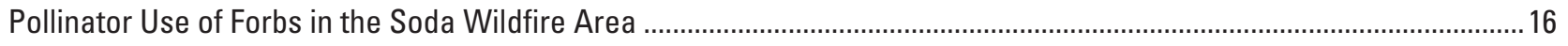

Environmental and Fire Interactions in Northern Great Basin Vegetation Communities ...................................................... 16

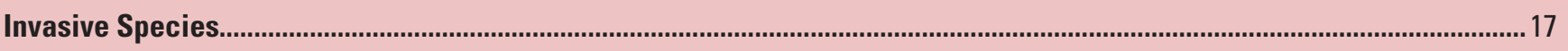

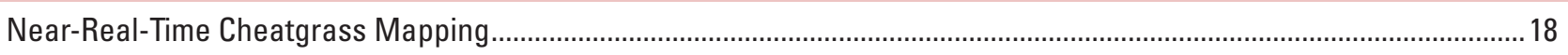

Cheatgrass Dynamics in the Northern Great Basin ............................................................................................ 19

Sagebrush Ecosystem Management in Light of Sage-Grouse, Fire, and Invasive Species ..............................................20

Spatial Variation in the Role of Climatic Extremes in Shaping Plant Invasions...................................................................21

Exotic Forbs in Disturbed Sagebrush Steppe ............................................................................................................ 21

Landscape-Scale Assessment of Emerging Techniques for Controlling Exotic Annual Grasses........................................21

Use of Cheatgrass-Suppressive Bacteria To Restore Sagebrush Steppe ........................................................................2

Evaluating a Novel Biopesticide for Controlling Exotic Annual Grasses Following Rangeland Wildfire..............................22

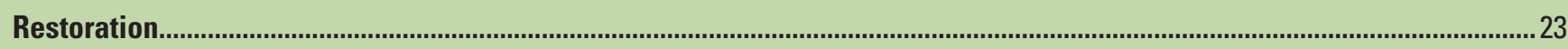

Field of Sagebrush Dreams: Sage-Grouse Responses to Burns and Sagebrush Restoration in

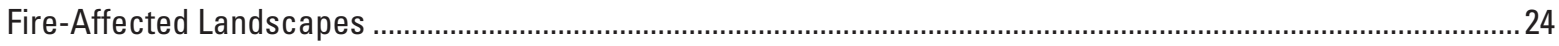

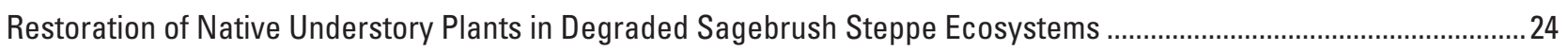

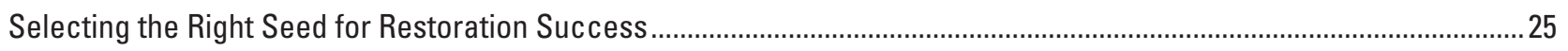

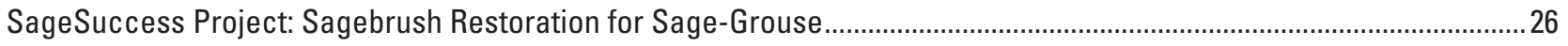

Assessing the Influence of Microsite Soil Characteristics on Sagebrush Restoration Success ........................................26

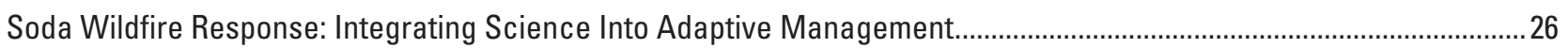

Modeling Recovery of Sagebrush Ecosystems Using Remote Sensing Products ............................................................2 27

Improving Sagebrush Ecosystem Resistance and Resilience To Inform Conservation .......................................................2 


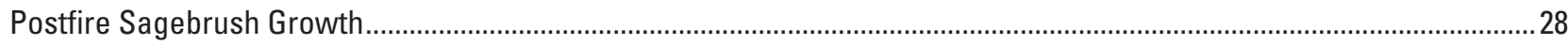

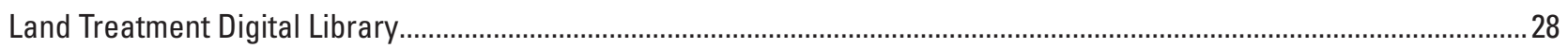

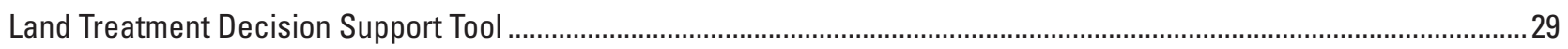

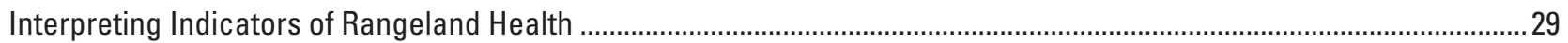

Effectiveness of Layering Treatments in the "Multiple Intervention" Response to Wildfire in Sagebrush Steppe ............30

Phasing Herbicide, Drill Seeding, and Grazing Resumption in Postfire Sagebrush Steppe .................................................30

Experimental Tests of Management Options for Improving Outplanting Success of Big Sagebrush ...............................30

Community Composition and Restoration of Biological Soil Crusts of Nevada's Sagebrush Steppe ..................................31

Holding Their Ground: Does Biological Soil Crust Restoration Enhance the Germination of Native Plants

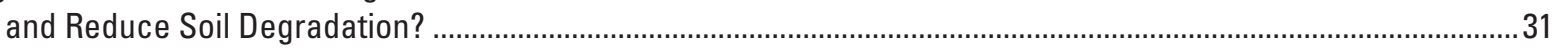

Decision Support for Conservation and Restoration Efforts in the Sagebrush Biome .........................................................32

Bureau of Land Management Seed Warehouse Database............................................................................................. 32

Sagebrush, Sage-Grouse, and Other Sagebrush-Associated Species …......................................................................................3

Annotated Bibliography of Scientific Research on Greater Sage-Grouse .........................................................................34

Greater Sage-Grouse Science (2015-17): Synthesis and Potential Management Implications ........................................34

Hierarchical Sage-Grouse Population Assessment Tool: Building a Foundation for True Adaptive Management..............35

Multiscale Statewide Wyoming Greater Sage-Grouse Trends Determined by Population Viability Analysis......................35

Using Advanced Technologies To Improve Population Estimation From Lek Counts ..........................................................36

The Importance of Simulation Assumptions When Evaluating Detection Bias in Lek Trend Models .................................36

Evaluating Trends in Greater Sage-Grouse Populations With Quantile Regression...............................................................36

A Hierarchical Integrated Population Model for Greater Sage-Grouse in the Bi-State Distinct Population

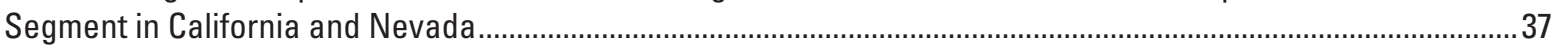

Spatially Explicit Conservation Planning Tool for the Bi-State Distinct Population Segment of

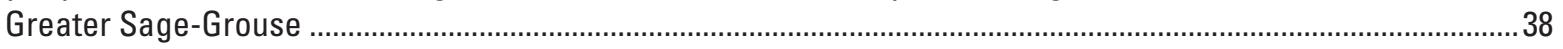

Translocations as Conservation Strategy for Imperiled Populations of Sage-Grouse .........................................................38

Greater Sage Grouse Response to Habitat Restoration Efforts...................................................................................

Spatially Explicit State-and-Transition Modeling for Rangeland Conservation Planning: Application

to Outcome-Based Grazing and Sage-Grouse Habitat Monitoring ..................................................................... 39

Learning From the Land: Extending State-and-Transition Models for Adaptive Management of Wildlife

Habitat on Western Rangelands .......................................................................................................................... 39

Prioritizing Habitats for Dynamic Populations Using a Spatially Explicit Population Approach for

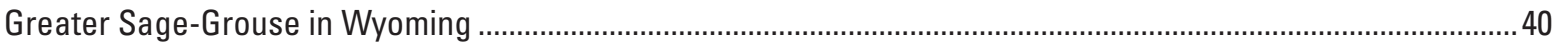

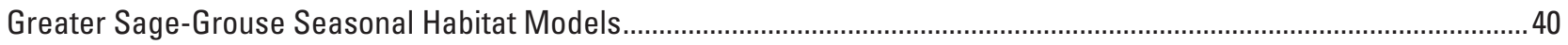

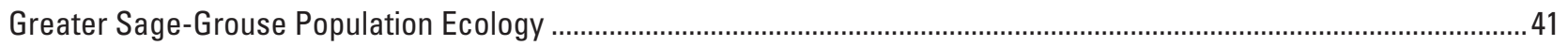

Microhabitat Requirements of Greater Sage-Grouse Within the Great Basin ............................................................... 41

SageDAT: Data and Tools To Support Collaborative Sagebrush Ecosystem Conservation and Management.................... 42

Remote Sensing Characterization and Monitoring of Shrubland Components in the

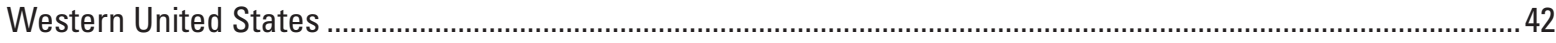

Developing Temporal Trends in Sagebrush Vegetation Characteristics Over a Large Landscape .................................... 43

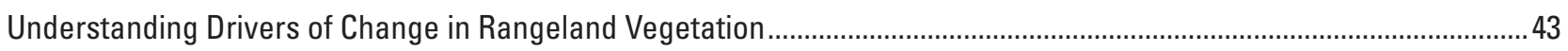

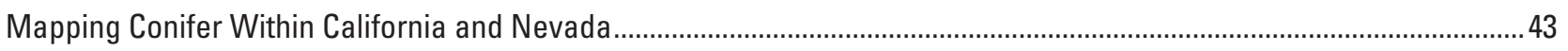

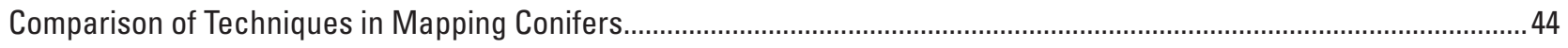

Mapping of Greater Sage-Grouse Habitat in Nevada and Northeastern California ........................................................... 45

Sagebrush Ecosystem Performance Mapping in the Great Basin................................................................................... 45

Landscape Influence on Gene Flow in Greater Sage-Grouse ................................................................................... 46

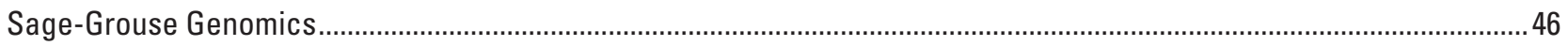


Genetic Implications of Translocations in Gunnison Sage-Grouse.................................................................................... 47

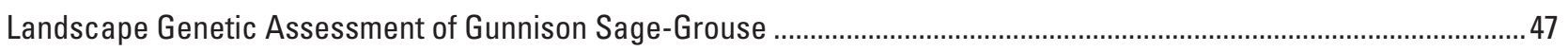

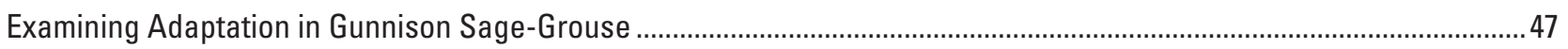

Identification of Crucial Late-Summer Brood-Rearing and Winter Habitat for Gunnison Sage-Grouse ............................. 48

Landscape Variability and Gunnison Sage-Grouse Conservation.................................................................................. 48

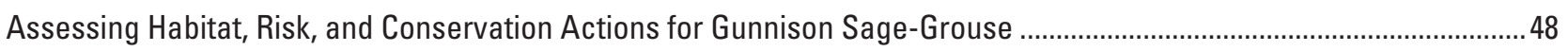

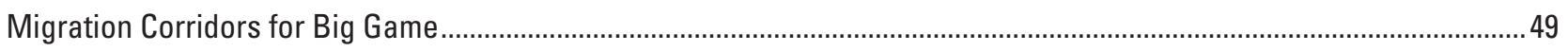

Interactions of Phenology, Grazing, Hunting, and Prescribed Fire on Elk in Southwestern Wyoming ..............................50

Sage-Grouse as an Umbrella Species for Nongame Species of Concern in Wyoming ....................................................50

Evaluating Biodiversity of Sagebrush-Dependent Species Within Sage-Grouse Habitat: An Example

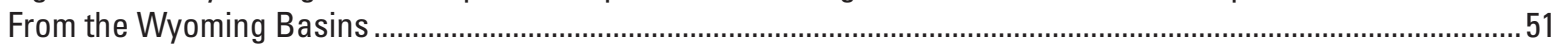

The Influence of Climatic Conditions on Reproduction of Sagebrush-Dependent Birds: Implications for

Climate Vulnerability Assessments and Habitat Prioritization Efforts.....................................................................51

Developing Regional and Local Decision Support Tools for Sagebrush and Grassland Ecosystems in

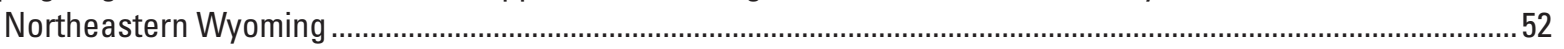

Fire-Cheatgrass Cycle Effects on Sagebrush Ecosystem Engineers.......................................................................... 52

Influence of Harvester Ants in Burned Areas Invaded by Exotic Annual Grasses ............................................................53

Smart Energy Development in the Sagebrush Ecosystem ........................................................................................... 53

Evaluating Reclamation Success Following Oil and Gas Development .......................................................................54

Using Long-Term Remote Sensing and an Automated Reference Toolset To Estimate and

Predict Post-Development Recovery Potential..................................................................................................... 55

Quantifying the Potential Effects of Energy Development on Wildlife and Ecosystem Services.......................................55

Greater Sage-Grouse Responses to Changes in Precipitation and Temperature and Future

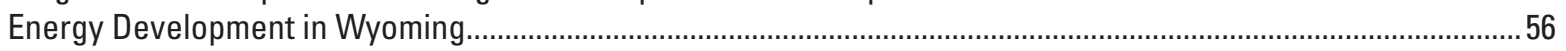

Mechanisms Underlying Sagebrush-Obligate Songbird Responses to Natural Gas Development...................................56

Pygmy Rabbit Distribution and Abundance Relative to Ongoing Energy Development in Wyoming ..................................57

Effects of Livestock Grazing on Greater Sage-Grouse................................................................................................. 57

Effects of Invasive Cheatgrass on Sage-Grouse in Nevada ................................................................................... 58

Implications of Anthropogenic Activities on Greater Sage-Grouse Populations in Nevada ................................................58

Effects of Pinyon and Juniper on Sage-Grouse Movement, Distribution, and Survival ....................................................58

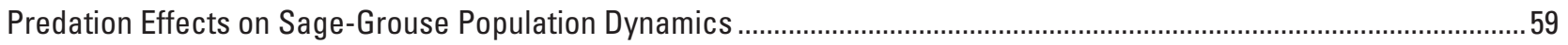

Raven Density and Management Across the Great Basin .........................................................................................59

Effects of Raven Removal on Nest Survival and Population Growth Rates of Greater Sage-Grouse..................................60

Plant Community Composition and Vegetation Structure in Core Sage-Grouse Habitats ................................................. 60

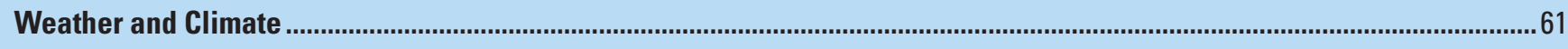

Postfire Wind Erosion and Integration of Weather Prediction Tools .................................................................................62

Mapping Projected Soil Temperature and Moisture Regimes in a Changing Climate.......................................................62

Assessing Vulnerability to Drought in Dryland Ecosystems of the Western United States ...................................................62

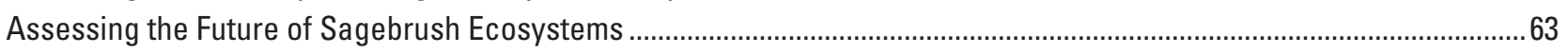

Weather-Centric Rangeland Revegetation Planning............................................................................................. 64

Understanding Changes in Sagebrush Distribution and Abundance Under Climate Change: Integration of

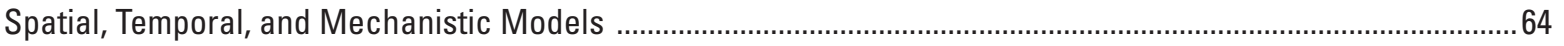

Response of Sagebrush Ecosystems to Precipitation Shifts ......................................................................................65

Phenological Responses to Long-Term Environmental Drivers in the Northern Great Plains ............................................66

Tracking Drought-Induced Variability in Sagebrush Ecosystem Productivity...................................................................6

Sagebrush Ecosystem Research Funded by Climate Adaptation Science Centers ...........................................................66 
U.S. Geological Survey.

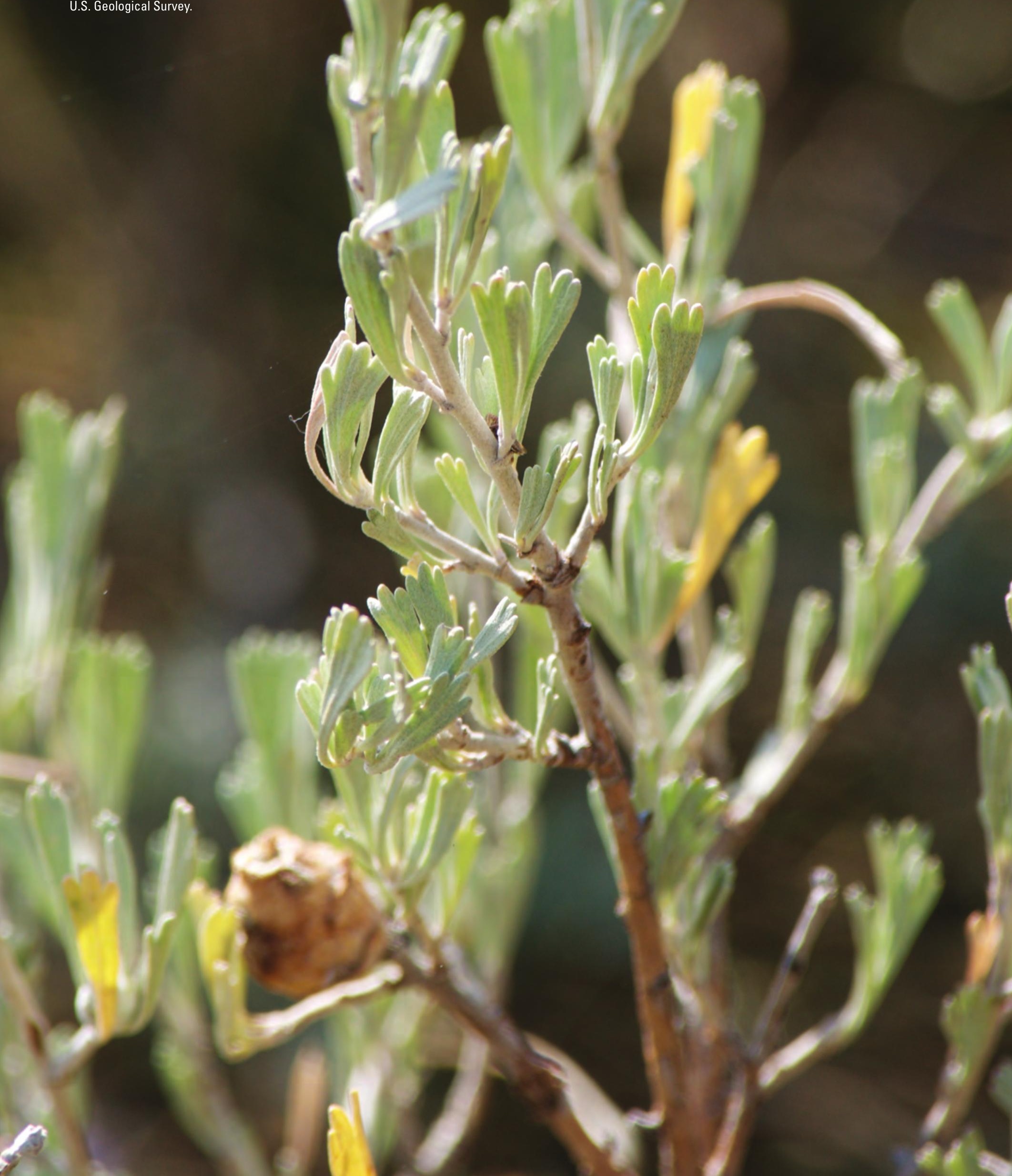

Sagebrush. Photograph by Justin Welty,

(3) 


\section{Project Descriptions}

These descriptions are overviews of projects that are ongoing or were active during 2018. Citations are provided for select products that have resulted from these efforts. Contact information is provided for the primary USGS scientist(s) for each project.

\section{Fire}

Fire is a significant threat to maintaining a large contiguous sagebrush ecosystem, and this threat has been intensifying owing to increases in highly flammable invasive annual grasses. USGS scientists are addressing a number of science needs including determining the effects and effectiveness of fuel treatments, understanding historic fire regimes in the sagebrush ecosystem, and assessing strategies to improve postfire management actions.

Fire in the sagebrush landscape. Photograph by Scott Shaff, U.S. Geological Survey. 


\section{Evaluating Effects and Effectiveness of Fuel Breaks}

Fuel breaks are intended to reduce fire size, frequency, and the rate at which fire spreads by disrupting fuel continuity, reducing fuel accumulation, or increasing plants with higher moisture content in strips or blocks of land. Land management agencies want better information about the effectiveness of fuel breaks, as well as potential ecological costs and benefits related to fuel breaks. To supply this information, USGS and U.S. Department of Agriculture (USDA) Forest Service scientists have synthesized available information on the ecological effects and effectiveness of fuel breaks, particularly linear fuel breaks across the Great Basin. By evaluating the extent to which fuel breaks protect existing habitat from wildland fire, as well as how they affect sagebrush habitat, sage-grouse, and other sagebrush-obligate species, this study provides information for managers as they assess tradeoffs between the potential risks and benefits of fuel breaks.

\section{Contact}

Douglas J. Shinneman, USGS Forest and Rangeland Ecosystem Science Center; dshinneman@usgs.gov; 208-426-5206

\section{Publication}

Shinneman, D.J., Aldridge, C.L., Coates, P.S., Germino, M.J., Pilliod, D.S., and Vaillant, N.M., 2018, A conservation paradox in the Great Basin-Altering sagebrush landscapes with fuel breaks to reduce habitat loss from wildfire: U.S. Geological Survey Open-File Report 2018-1034, 70 p., https://doi.org/10.3133/ofr20181034.

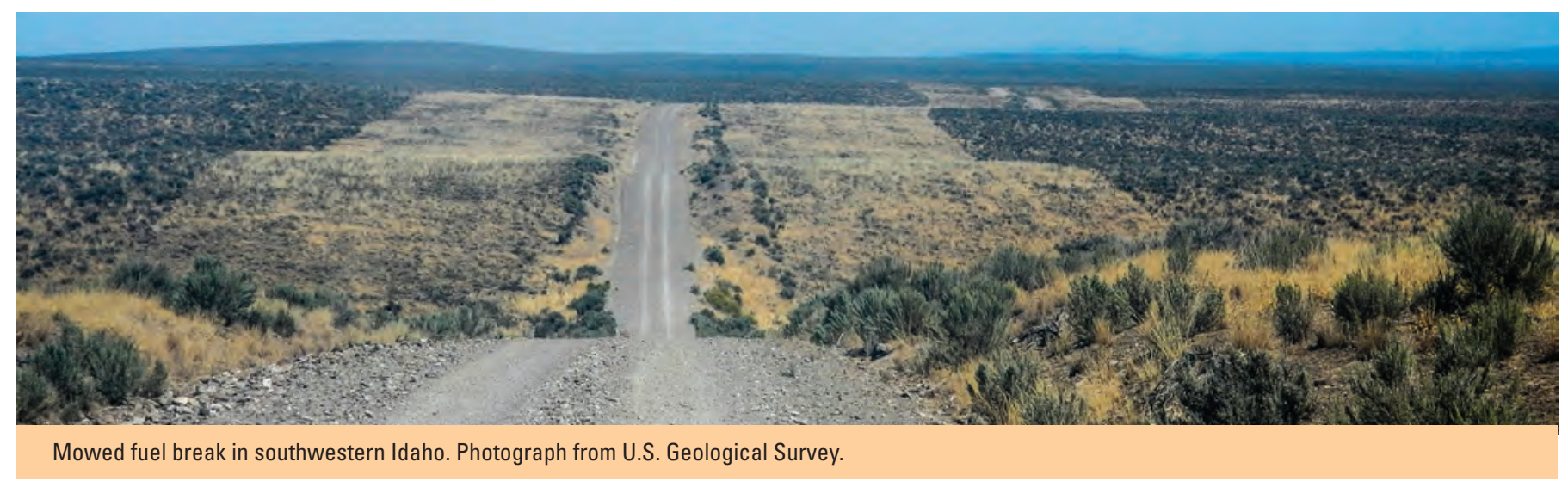

\section{Assessing the Effectiveness of Fuel Breaks for Preserving Greater Sage-Grouse in the Great Basin}

Fuel breaks have the potential to minimize catastrophic losses of sagebrush habitat and sage-grouse populations by altering fire behavior and facilitating fire suppression. However, they may carry risks to sage-grouse populations — of habitat loss, fragmentation, cheatgrass (Bromus tectorum) invasion, and alteration of sage-grouse movements - that have not been quantified. USGS and Colorado State University (CSU) scientists are working with the Bureau of Land Management (BLM) to (1) quantify sage-grouse response to fuel breaks; (2) use high-resolution data to compare fire sizes and spread among areas with and without fuel breaks; (3) combine data for fuel breaks and past fire behavior, sage-grouse habitat and population dynamics, and sagegrouse responses to fuel breaks and fires within a spatially explicit individual-based model; and (4) model the effects of fuel breaks on sage-grouse populations under alternative scenarios of population responses, altered fire regimes, fuel break designs, and fire management access. Results of this study will help identify the important factors needed for the strategic placement of fuel breaks to suppress wildfire in sage-grouse habitats, and minimize negative impacts on populations.

\section{Contacts}

Cameron L. Aldridge, Colorado State University, in cooperation with USGS Fort Collins Science Center; aldridgec@usgs.gov; 970-226-9433

Julie A. Heinrichs, Colorado State University, in cooperation with USGS Fort Collins Science Center; jheinrichs@usgs.gov; 970-226-9149

Peter S. Coates, USGS Western Ecological Research Center; pcoates@usgs.gov; 530-669-5073

Douglas J. Shinneman, USGS Forest and Rangeland Ecosystem Science Center; dshinneman@usgs.gov; 208-426-5206 


\section{Evaluating Effects of Woody Fuels Treatments on Native and Nonnative Plants in the Sagebrush Biome}

When sagebrush becomes overcrowded, it presents significant wildfire risk. Managers often reduce woody fuels through various techniques that may have undesirable consequences for native vegetation. USGS scientists and collaborators evaluated a combination of prescribed fire, mowing, and herbicide treatments to reduce woody shrubs to study how treatments affected other plant species and land health indicators. USGS scientists and collaborators have completed 9 or more years of research on these sites and will be able to provide information on the long-term outcomes of these treatments.

\section{Contact}

David A. Pyke, USGS Forest and Rangeland Ecosystem Science Center; david_a_pyke@usgs.gov; 541-750-0989

\section{Publications}

Pyke, D.A., Shaff, S.E., Lindgren, A.I., Schupp, E.W., Doescher, P.S., Chambers, J.C., Burnham, J.S., and Huso, M.M., 2014, Region-wide ecological responses of arid Wyoming big sagebrush communities to fuel treatments: Rangeland Ecology \& Management, v. 67, no. 5, p. 455-467, https://doi.org/10.2111/REM-D-13-00090.1.

Roundy, B.A., Chambers, J.C., Pyke, D.A., Miller, R.F., Tausch, R.J., Schupp, E.W., Rau, B., and Gruell, T., in press, Resilience and resistance in sagebrush ecosystems are associated with seasonal soil temperature and water availability: Ecosphere.

\section{Assessing the Proliferation, Connectivity, and Consequences of Invasive Fine Fuels}

Invasive annual grasses (fine fuels) are a significant challenge for land and wildlife management. USGS and CSU scientists are working with the BLM to understand the potential consequences of invasive annual grass proliferation and connectivity on fire behavior and loss of sagebrush in the Great Basin. Landscape disturbances and management activities that create linear features (for example, roads, fuel breaks, transmission lines) often occur adjacent to existing fine fuels and may lead to further spread of invasive annual grasses. The scientists will develop scenarios of future invasion to assess impacts of potential future disturbances and use simulations to compare the effects of disturbance and invasion among current and future landscapes. This project will help develop strategies for managing annual invasive grasses, thus minimizing the potential loss of sage-grouse habitat.

\section{Contacts}

Julie A. Heinrichs, Colorado State University, in cooperation with USGS Fort Collins Science Center; jheinrichs@usgs.gov; 970-226-9149

Helen Sofaer, USGS Fort Collins Science Center; hsofaer@usgs.gov; 970-226-9173

Daniel J. Manier, USGS Fort Collins Science Center; manierd@usgs.gov; 970-226-9466

Cameron L. Aldridge, Colorado State University, in cooperation with USGS Fort Collins Science Center; aldridgec@usgs.gov; 970-226-9433

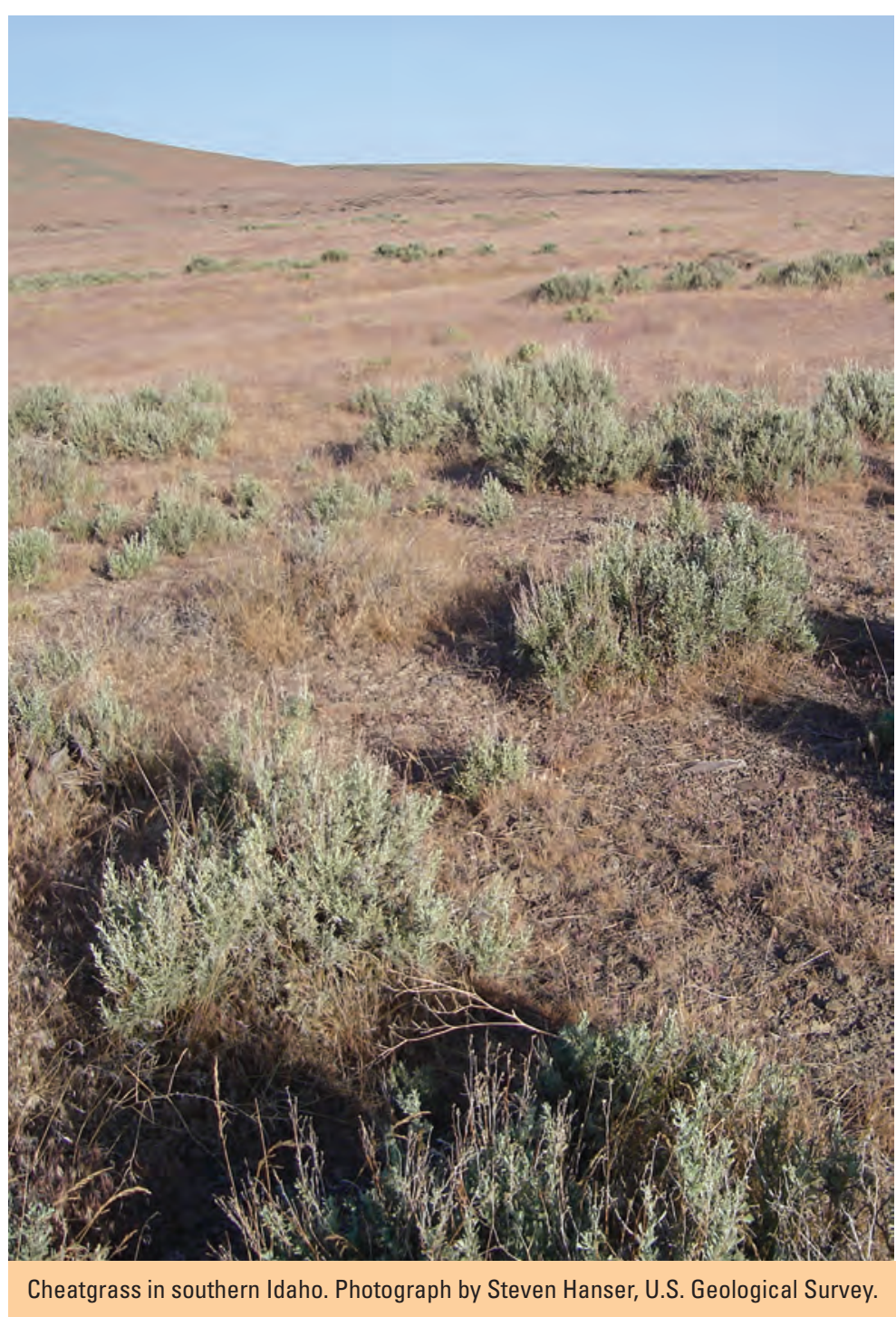




\section{Quantifying Fuels and the Effects of Reduction Treatments in Sagebrush Habitats}

Invasive annual plants create fine fuels that have increased wildfire frequency in the sagebrush habitats of the Great Basin. Land managers have invested considerable funding to decrease fuel loads, using techniques such as grazing, mowing, herbicides, and seeding with native and nonnative species. Yet, little information is available about how such restoration activities have influenced fuel loads. USGS scientists and university colleagues are developing a new approach to better quantify and predict fuel loads and the effects of fuel manipulations in sagebrush habitats. At study sites in southwestern Idaho, they are comparing the efficiency of commonly used restoration treatments and using remote sensing to estimate fuel loads and provide large-scale assessments of fuel conditions. The assessments will help land managers and fire scientists predict fire risk, assess effects of management activities on fuel loads and native species, and assess short- and long-range fire effects.

\section{Contacts}

Douglas J. Shinneman, USGS Forest and Rangeland Ecosystem Science Center; dshinneman@usgs.gov; 208-426-5206

David S. Pilliod, USGS Forest and Rangeland Ecosystem Science Center; dpilliod@usgs.gov; 208-426-5202

\section{Publications}

Anderson, K.E., Glenn, N.F., Spaete, L.P., Shinneman, D.J., Pilliod, D.S., Arkle, R.S., McIlroy, S.K., and Derryberry, D.R., 2017, Methodological considerations of terrestrial laser scanning for vegetation monitoring in the sagebrush steppe: Environmental Monitoring and Assessment, v. 189, no. 11, article 578, 12 p., https://doi.org/10.1007/s10661-017-6300-0.

Anderson, K.E., Glenn, N.F., Spaete, L.P., Shinneman, D.J., Pilliod, D.S., Arkle, R.S., McIlroy, S.K., and Derryberry, D.R., 2018, Estimating vegetation biomass and cover across large plots in shrub and grass dominated drylands using terrestrial lidar and machine learning: Ecological Indicators, v. 84, p. 793-802, https://doi.org/10.1016/j.ecolind.2017.09.034.

Brabec, M.M., Germino, M.J., Shinneman, D.J., Pilliod, D.S., McIlroy, S.K., and Arkle, R.S., 2015, Challenges of establishing big sagebrush (Artemisia tridentata) in rangeland restoration-Effects of herbicide, mowing, whole-community seeding, and sagebrush seed sources: Rangeland Ecology \& Management, v. 68, no. 5, p. 432-435, https://doi.org/10.1016/ j.rama.2015.07.001.

Glenn, N.F., Neuenschwander, A., Vierling, L.A., Spaete, L., Li, A., Shinneman, D.J., Pilliod, D.S., Arkle, R.S., and Mcllroy, S.K., 2016, Landsat 8 and ICESat-2-Performance and potential synergies for quantifying dryland ecosystem vegetation cover and biomass: Remote Sensing of Environment, v. 185, p. 233-242, https://doi.org/10.1016/j.rse.2016.02.039.

Li, A., Shital, D., Glenn, N.F., Spaete, L.P., Shinneman, D.J., Pilliod, D.S., Arkle, R.S., and Mcllroy, S.K., 2017, Lidar aboveground vegetation biomass estimates in shrublands-Prediction, uncertainties and application to coarser scales: Remote Sensing, v. 9, no. 9, article 903, 19 p., https://doi.org/10.3390/rs9090903.

\section{Long-Term Effects of Treatments on Fuel Loads and Fire Regimes in the Great Basin}

The Great Basin is vulnerable to changes in fuels and fire regimes as a result of invasive species and climate change. To address these threats, management agencies are using fuel reduction and seeding treatments designed to reduce fire intensity, spread, and risk. To assess the ecological impacts and long-term effectiveness of these treatments, USGS scientists and university collaborators are evaluating future scenarios of ecosystem dynamics using models that incorporate climate change, fire regimes, and fuel treatments. They are examining potential vegetation response to changing climate, fuel treatments, and postfire seedings and assessing implications for repeated fuels maintenance under several future climate scenarios. Results may be used by land managers and fuels experts engaged in sagebrush ecosystem land use planning and fire management activities, including to design more-effective fire suppression strategies.

\section{Contacts}

Douglas J. Shinneman, USGS Forest and Rangeland Ecosystem Science Center; dshinneman@usgs.gov; 208-426-5206

David S. Pilliod, USGS Forest and Rangeland Ecosystem Science Center; dpilliod@usgs.gov; 208-426-5202

\section{Publication}

Pilliod, D.S., Welty, J.L., and Arkle, R.S., 2017, Refining the cheatgrass-fire cycle in the Great Basin-Precipitation timing and fine fuel composition predict wildfire trends: Ecology and Evolution, v. 7, no. 19, p. 8126-8151, https://doi.org/10.1002/ ece3.3414. 


\section{Future Fire in the Great Basin}

Understanding where, when, and why fires occur, how they may change in the future, and what their implications are for land management is fundamental to virtually all aspects of rangeland fire prevention, management, and restoration. USGS scientists are analyzing why fires occur and projecting where and when fire regimes will shift under expected future conditions. The researchers will evaluate some of the assumptions regarding altered fire regimes that are incorporated into the Fire and Invasives Assessment Tool (FIAT). This effort will determine the degree to which recurrent fire and invasive annual grass dominance (evidence of a fire-grass cycle) are associated with the warm and dry soils and identify localities that have the strongest evidence for this relationship. This information can help managers prioritize their efforts within the extensive landscapes with warm and dry soils that lead to low resistance to invasion and resilience following disturbance.

\section{Contacts}

Douglas J. Shinneman, USGS Forest and Rangeland Ecosystem Science Center; dshinneman@usgs.gov; 208-426-5206

Matthew L. Brooks, USGS Western Ecological Research Center; mlbrooks@usgs.gov; 559-240-7622

\section{Publication}

Brooks, M.L., Matchett, J.R., Shinneman, D.J., and Coates, P.S., 2015, Fire patterns in the range of greater sage-grouse, 1984-2013-Implications for conservation and management: U.S. Geological Survey Open-File Report 2015-1167, 66 p., https://doi.org/10.3133/ofr20151167.

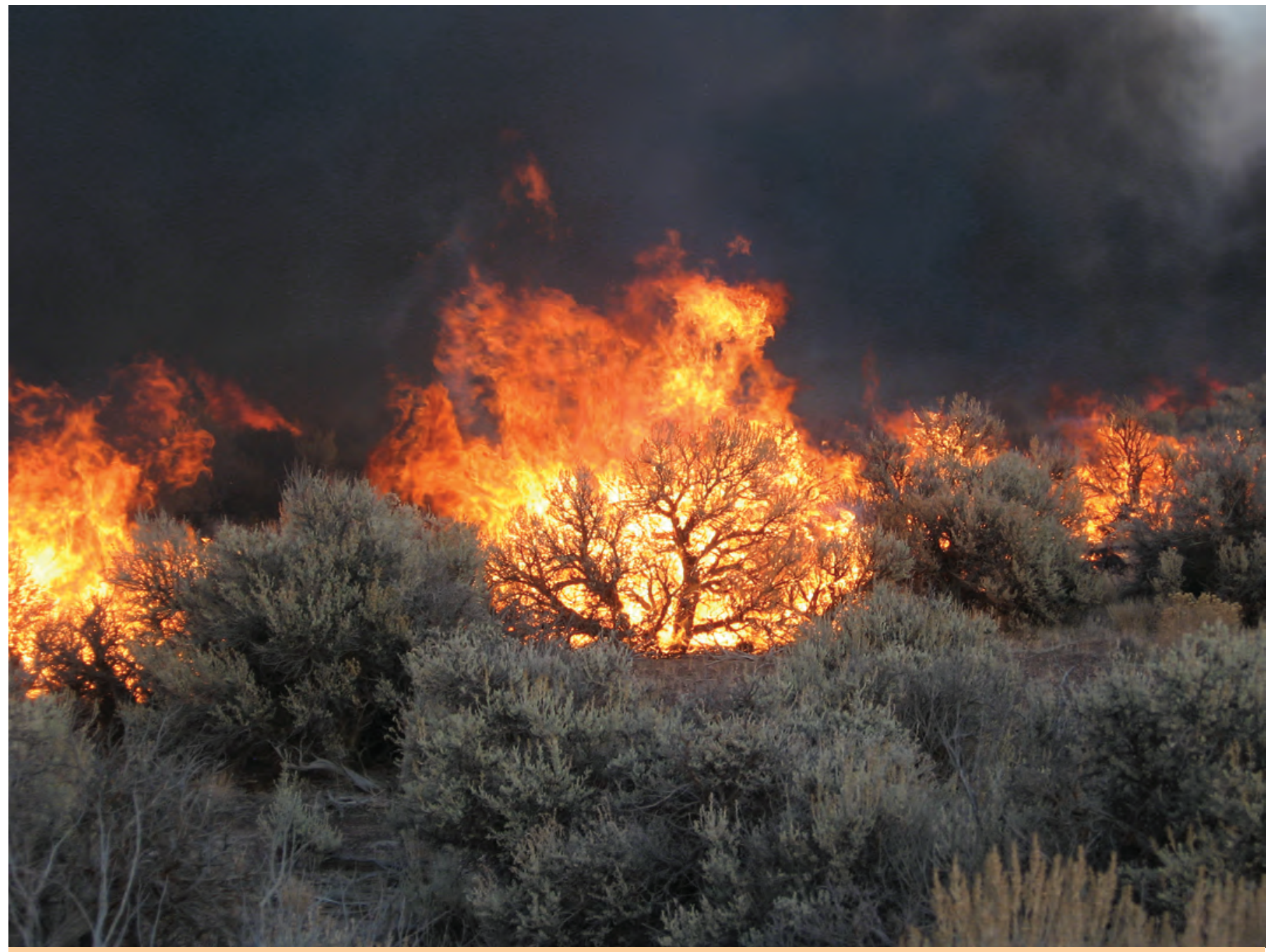

Fire in big sagebrush. Photograph by Scott Shaff, U.S. Geological Survey. 


\section{Identifying the Effects of Reoccurring Fire on Sagebrush Ecosystems in the Northern Columbia Basin}

Most sagebrush ecosystems are adapted to relatively long fire return intervals, but frequent fires are becoming common across these landscapes. A decrease in the time between fires may delay ecosystem recovery and enhance the rate of conversion to nonnative species dominance. USGS research is identifying differences in successional trajectories across three burn frequencies in a sagebrush landscape in the northern Columbia Basin (NCB) in Washington State by determining (1) how key ecosystem vegetation characteristics, including fuels, differ across sagebrush sites that have burned once, twice, or three times over a 13-year period; (2) the impact of repeated fire on soil structure and function; and (3) how these characteristics at burned sites compare to nearby unburned sites. Investigating recovery using both vegetation and soils data will provide a comprehensive analysis on the effects of recurring fire on sagebrush ecosystems across the NCB.

\section{Contact}

Douglas J. Shinneman, USGS Forest and Rangeland Ecosystem Science Center; dshinneman@usgs.gov; 208-426-5206

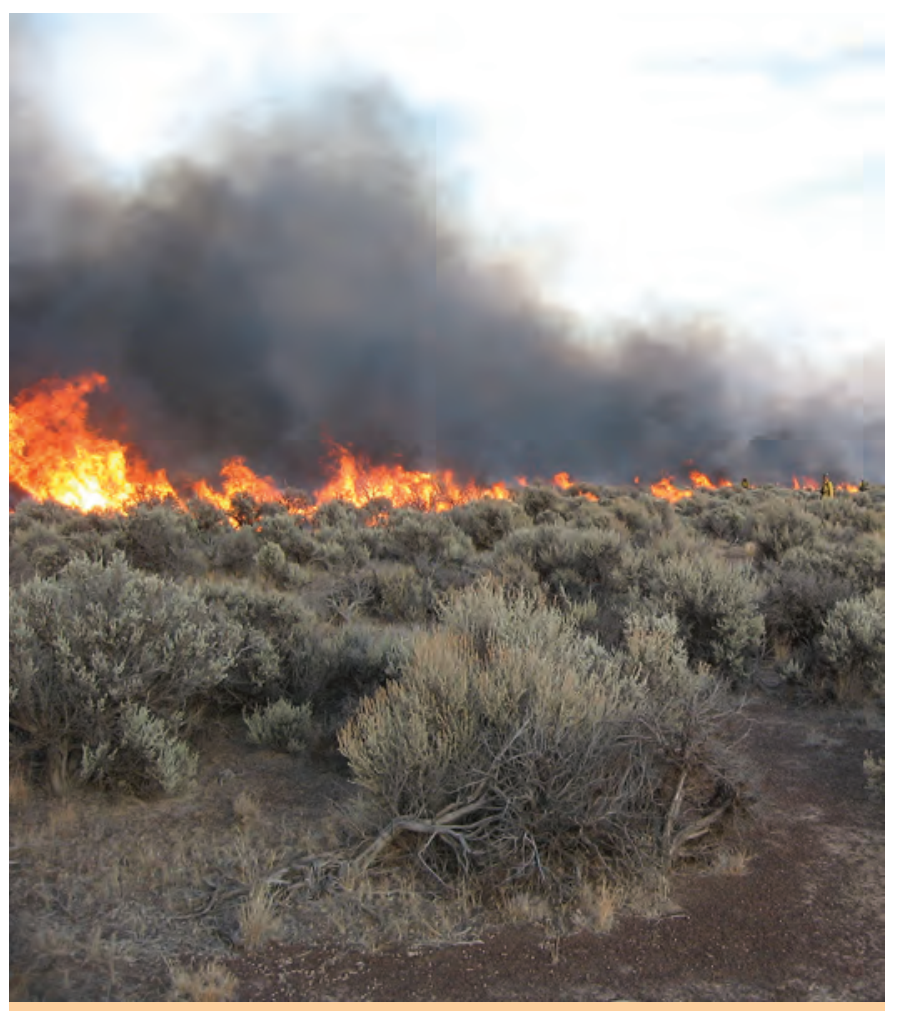

Controlled burn at Hart Mountain National Wildlife Refuge. Photograph by Scott Shaff, U.S. Geological Survey.

\section{Effects of Large-Scale Wildfire on Habitat Use and Demography of Female Greater Sage-Grouse in Southeastern Oregon}

One of the key stressors for sage-grouse in the Great Basin is the conversion of sagebrush habitat to annual grasses through catastrophic wildfire. In August 2012, the Holloway Fire burned approximately 460,000 acres in highly productive sage-grouse habitat in northern Nevada and southeastern Oregon. USGS Oregon Cooperative Fish and Wildlife Research Unit, Oregon State University, and Oregon Department of Fish and Wildlife scientists initiated a long-term study in 2013 (now in its sixth consecutive year) using the Holloway Fire to address the initial, acute effects as well as the longer term, chronic effects of large-scale wildfire on the habitat use and demographics of female greater sage-grouse. Female survival, reproductive ecology and success, and habitat selection are being monitored continuously to gain key information on the behavioral and demographic responses of female sage-grouse to a large-scale disturbance event and how those responses change relative to time since disturbance. This information will provide mangers with information regarding postfire management and help identify potential options for maintaining sage-grouse populations.

\section{Contact}

Katie M. Dugger, USGS Oregon Cooperative Fish and Wildlife Research Unit; cdugger@usgs.gov; 541-737-2473

\section{Publication}

Foster, L.J., Dugger, K.M., Hagen, C.A., and Budeau, D.A., in press, Acute effects of wildfire on greater sage-grouse vital rates: Journal of Wildlife Management.

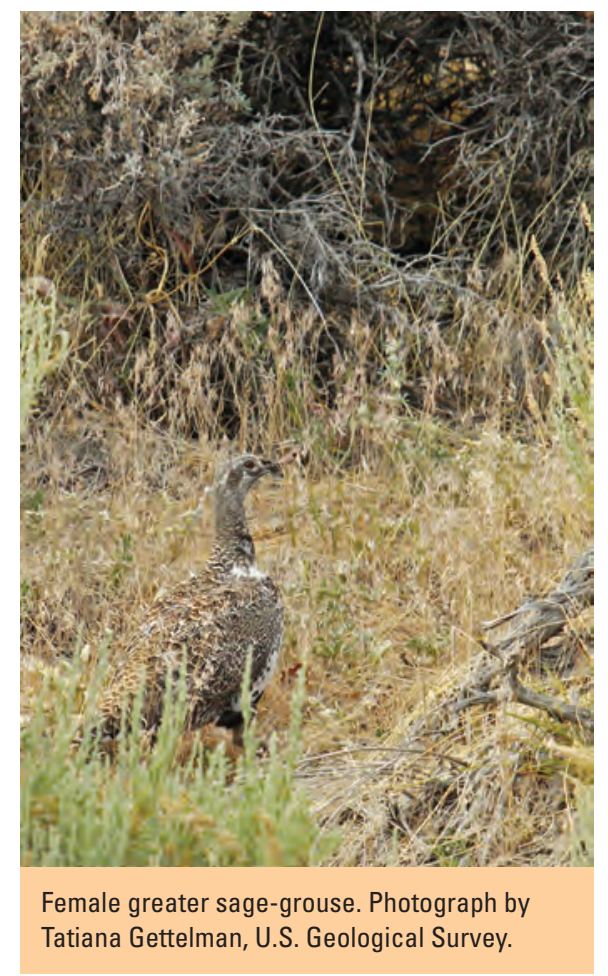




\section{Wildfire Effects on Sage-Grouse: A Before and After Case Study}

In 2012, the Rush Fire burned more than 300,000 acres of priority sage-grouse habitat in northeastern California and northwestern Nevada. The burned area was considered the core of the remaining sage-grouse population in northern California. Beginning in fall 2014, the USGS implemented a study to compare postfire vital rates, resource utilization, and genetics to the same measures from the same area before the fire. Now in its fourth consecutive year, this ongoing study will increase ecological understanding of how sage-grouse respond demographically and spatially to wildfire and will help land managers better evaluate the efficacy of postfire actions designed to restore sagebrush habitat and ecosystem services.

\section{Contact}

Peter S. Coates, USGS Western Ecological Research Center; pcoates@usgs.gov; 530-669-5073

\section{Response of Shrubland Birds to Prescribed-Fire and Mechanical Treatments}

Prescribed fire and mechanical cutting are commonly used to reduce the cover of pinyon (Pinus spp.) or juniper (Juniperus spp.) and are thought to benefit sagebrush-dependent birds, particularly sage-grouse. As part of the SageSTEP project, USGS scientists studied yearly changes in the bird community after woodland reduction to measure how birds use the new vegetative structure and to evaluate the bird community response. Results 5 to 7 years posttreatment suggest that prescribed fire, as currently conducted in established woodland communities, is relatively ineffective in creating habitat for sagebrush-obligate birds. In addition, fires reduced existing sagebrush cover, further delaying the establishment of a desired sagebrush bird community. In contrast, mechanical treatments that removed all tree cover at locations adjacent to existing sagebrush landscape were effective in restoring sagebrush bird communities. However, bird communities at treated locations were not stable up to 7 years posttreatment and continue to diverge from the pretreatment community. As a result, managers may expect long-term response times when evaluating the effectiveness of treatments.

\section{Contact}

Steven E. Hanser, USGS Ecosystems Mission Area; shanser@usgs.gov; 703-648-4054

\section{Publications}

Knick, S.T., Hanser, S.E., Grace, J.B., Hollenbeck, J.P., and Leu, M., 2017, Response of bird community structure to habitat management in piñon-juniper woodland-sagebrush ecotones: Forest Ecology and Management, v. 400, p. 256-268, https://doi.org/10.1016/j.foreco.2017.06.017.

Knick, S.T., Hanser, S.E., and Leu, M., 2014, Ecological scale of bird community response to piñon-juniper removal: Rangeland Ecology \& Management, v. 67, no. 5, p. 553-562, https://doi.org/10.2111/REM-D-13-00023.1.

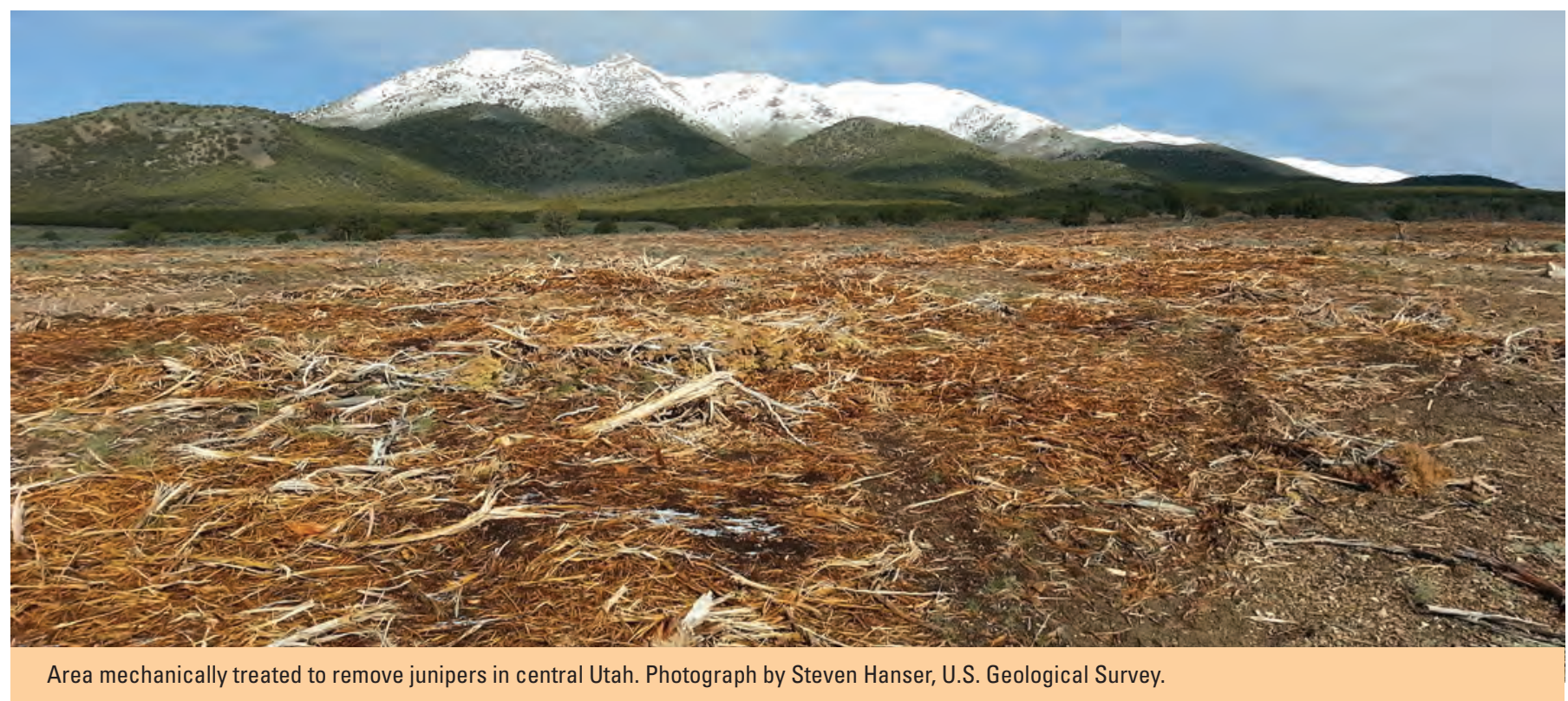




\section{Effects of Wildfire and Climate on Persistence of Greater Sage-Grouse}

Wildfire and climate change are frequently identified as important factors contributing to the decline of sage-grouse populations, yet fire regimes and climate patterns can vary substantially across broad geographic ranges. Using three decades of sage-grouse population counts, wildfire information, and climate data, USGS scientists linked long-term declines of sage-grouse to chronic effects of wildfire across the Great Basin. The analysis indicated that projected declines may be slowed or halted by targeting remaining areas of intact sagebrush with high densities of breeding sage-grouse for fire suppression. Ongoing research is determining how wildfire affects long-term sage-grouse population dynamics across their entire range and how variation in postfire recovery of sagebrush ecosystems modulates impacts of wildfire on sage-grouse population growth. Researchers are also using simulation analysis to better understand tradeoffs between restoration and suppression efforts in reducing long-term impacts to sage-grouse populations.

\section{Contact}

Peter S. Coates, USGS Western Ecological Research Center; pcoates@usgs.gov; 530-669-5073

\section{Publication}

Coates, P.S., Ricca, M.A., Prochazka, B.G., Brooks, M.L., Doherty, K.E., Kroger, T., Blomberg, E.J., Hagen, C.A., and Casazza, M.L., 2016, Wildfire, climate, and invasive grass interactions negatively impact an indicator species by reshaping sagebrush ecosystems: Proceedings of the National Academy of Sciences, v. 113, no. 45, p. 12745-12750, https://doi.org/10.1073/pnas.1606898113.

\section{Perennial Grass Response to Postfire Grazing Management in the Great Basin}

Perennial grasses are a vital component of a functioning sagebrush ecosystem and an important source of food for grazing cattle. In the event of a wildfire, burned perennial grasses need time to recover-but when are perennial grasses stable enough to accommodate grazing again? USGS scientists are investigating seasonal timing of grazing after fires and the length of grazing rest after fire to determine how these factors affect perennial grass recovery. In addition, this study is examining the length of grazing rest after postfire seeding to determine any impacts on seedling establishment and growth. Results can inform managers' recommendations for postfire management of livestock grazing when rehabilitation of sagebrush steppe habitat is the focus. Findings could also guide postfire grazing management on lands that provide critical sage-grouse habitat.

\section{Contact}

David A. Pyke, USGS Forest and Rangeland Ecosystem Science Center; david_a_pyke@usgs.gov; 541-750-0989

\section{Vegetation Responses to Sagebrush-Reduction Treatments Measured by Satellites}

Plant phenology and productivity are important habitat factors that influence resource use and migration of many wildlife species, but effects of sagebrush-reduction treatments on these vegetative characteristics are poorly understood. USGS scientists are comparing satellite-based metrics of vegetative cover, phenology, and productivity at sagebrush-dominated sites treated with fire, herbicide, and mechanical removals to paired, untreated sites. Results from this study will advance understanding of sagebrush recovery following disturbance and inform managers on the effectiveness of their actions.

\section{Contact}

Aaron N. Johnston, USGS Northern Rocky Mountain Science Center; ajohnston@usgs.gov; 406-994-7158 


\section{Use of Sagebrush-Reduction Treatments by Mule Deer in Wyoming}

In southwestern Wyoming, sagebrush-reduction treatments are applied to improve habitat for mule deer (Odocoileus hemionus), but recent population declines have raised concern over habitat management and integrity of migration routes. Plant phenology and productivity influence deer migration and can be altered by changes in vegetative communities associated with sagebrush treatments. Mismatches in plant phenology between treated and untreated areas could result in disrupted migration routes or suboptimal foraging for ungulates. USGS scientists are evaluating the use of sagebrush-reduction treatments by deer tracked with satellite telemetry for several years in Wyoming. The objectives are to determine whether (1) deer use sagebrush treatments differently from surrounding areas, (2) sagebrush treatments disrupt migration routes or alter the use of winter range, and (3) effects vary with treatment type (for example, fire, herbicide, mechanical) and time since treatment. This study can provide wildlife managers with information regarding potential effects of sagebrush reduction treatment on this important game species.

\section{Contact}

Aaron N. Johnston, USGS Northern Rocky Mountain Science Center; ajohnston@usgs.gov; 406-994-7158

\section{How Fire and Postfire Seeding Alter Pollinators in Sagebrush Habitat}

Wildfire and subsequent postfire restoration are common in western North America, yet information on how these events alter animal communities is generally lacking, especially for insect pollinators. USGS scientists compared insect pollinator assemblages in locations that burned 1 to 20 years prior to nearby unburned locations in sagebrush steppe habitats in southwestern Idaho. In some locations they also compared the diversity and abundance of pollinators in burned areas that were seeded after wildfire relative to burned areas that were not seeded. Other investigations examined the visitation of pollinators to small forb "islands" planted within burned areas to test this as an alternative strategy or supplement to drill seeding. This combination of studies will reveal important information about forb-pollinator interactions and the effectiveness of restoring forbs to burned areas.

\section{Contact}

David S. Pilliod, USGS Forest and Rangeland Ecosystem Science Center; dpilliod@usgs.gov; 208-426-5202

\section{Publication}

Pilliod, D.S., Rohde, A.T., Novak, S.J., in press, Insect communities in big sagebrush habitat remain altered by wildfire and postfire restoration seeding 15 years after disturbance and treatment: Insect Conservation and Diversity.

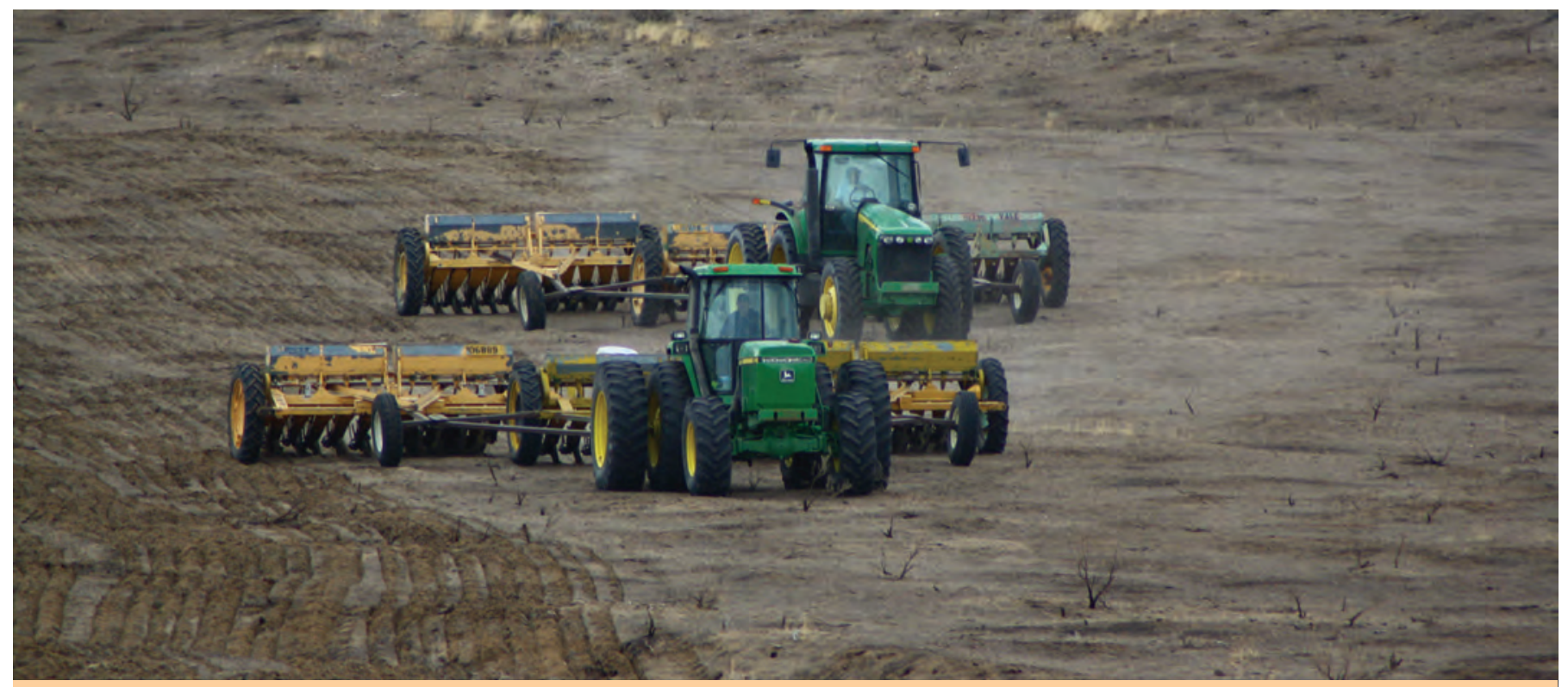




\section{Pollinator Use of Forbs in the Soda Wildfire Area}

Pollinating insects are in serious decline across the United States, affecting native plants. In a new study, USGS scientists will examine insect pollinator communities and forb-pollinator relationships at treatments across the area burned by the 2015 Soda Wildfire in southwestern Idaho and southeastern Oregon. Researchers will compare pollinators in seeded burned areas to unburned areas outside the Soda Wildfire. Researchers will also compare pollinator use of seeded forbs versus nonseeded forbs, as well as native versus nonnative forbs. This research will contribute to the understanding of pollinators on public lands, and inform pollinator conservation planning efforts.

\section{Contact}

David S. Pilliod, USGS Forest and Rangeland Ecosystem Science Center; dpilliod@usgs.gov; 208-426-5202

\section{Publication}

Sun, E.R., and Pilliod, D.S., in press, Identification of bees in southwest Idaho-A guide for beginners: U.S. Geological Survey Circular 1448, https://doi.org/10.3133/cir1448.

\section{Environmental and Fire Interactions in Northern Great Basin Vegetation Communities}

Management of sagebrush communities is complicated by varied responses to the intensity and location of disturbances. USGS scientists, in collaboration with the BLM Assessment Inventory and Monitoring Program, are examining sites within sagebrush communities of the northern Great Basin to identify how the cover of native shrubs and grasses and invasive plants respond to disturbances, while also considering the influence of climate factors. BLM monitoring plots are found within landscapes of varying overall surface disturbance and within burned and unburned areas. Burned plots represent a range of fire severities and years since fire, allowing an examination of foliar cover, community composition, and recovery times following disturbances of mixed severity and overlap. Identifying the factors leading to increased sagebrush community resistance and resilience can help mangers prioritize actions and identify sound management options.

\section{Contact}

David J.A. Wood, USGS Northern Rocky Mountain Science Center; dwood@usgs.gov; 406-896-5246

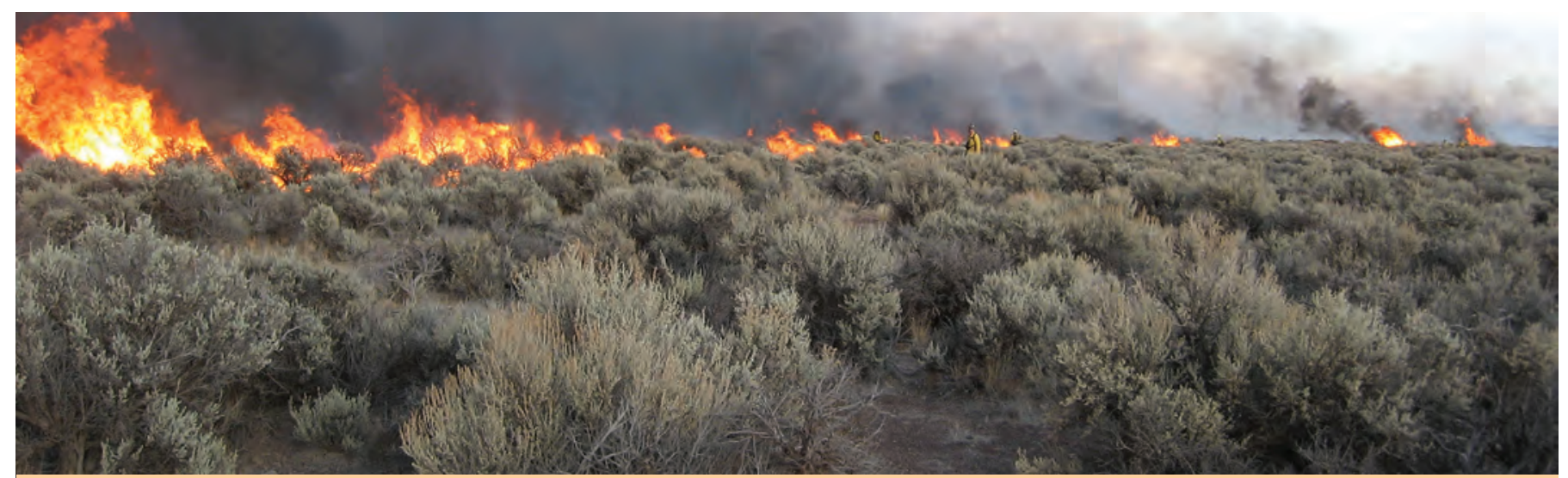

Controlled burn at Hart Mountain National Wildlife Refuge, Oregon. Photograph by Scott Shaff, U.S. Geological Survey. 


\section{Invasive Species}

Invasive plant species, primarily cheatgrass, are a significant threat to the sagebrush ecosystem by increasing fire frequency and competition with native plant species. USGS scientists are (1) addressing the need to develop and assess prevention, eradication, and control measures for invasive plant species; (2) determining the factors that influence invasive plant species distributions; and (3) developing maps to inform early detection and other control measures.

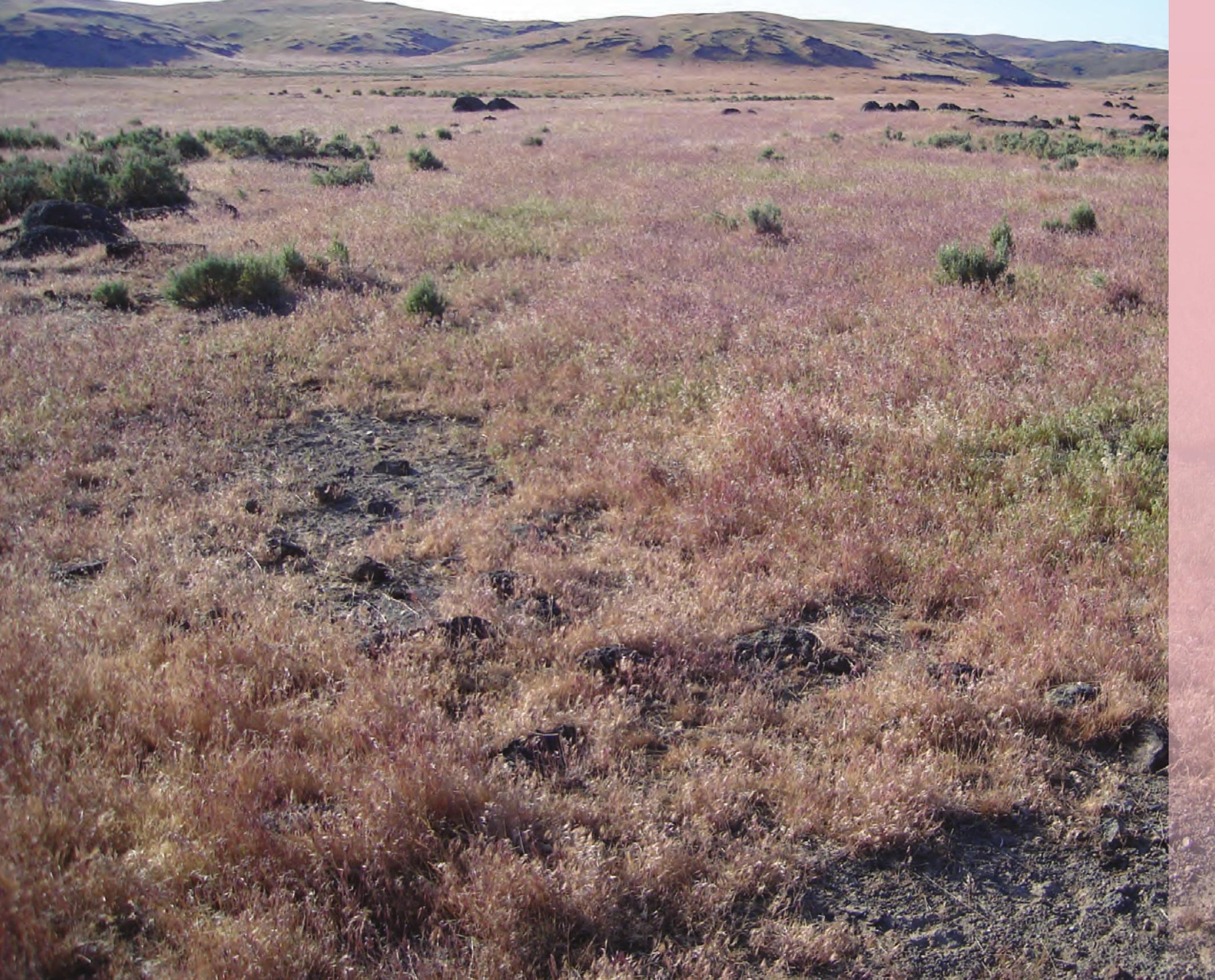




\section{Near-Real-Time Cheatgrass Mapping}

Mapping the invasion of sagebrush shrubland by cheatgrass in near realtime can help land managers understand the current distribution of cheatgrass and the potential risk for fire in the current year. USGS scientists have developed techniques that enable annual mapping of cheatgrass distributions. Maps have been made for the Great Basin and across Wyoming to provide a time series back to 2000. With recent analytical developments, researchers can annually produce 250-meter-resolution cheatgrass distribution maps by late May for the current year to inform fire suppression activities and other management activities, such as application of weed suppressive bacteria, targeted grazing, and other cheatgrass control measures. Map products at a higher resolution (30 meters) are under development and will help inform local-scale research and management efforts.

\section{Contact}

Bruce K. Wylie, USGS Earth Resources Observation and Science Center; wylie@usgs.gov; 605-594-6078

\section{Publications}

Boyte, S.P., and Wylie, B.K., 2016, Near-real-time cheatgrass percent cover in the northern Great Basin, USA, 2015: Rangelands, v. 38, no. 5, p. 278-284, https://doi.org/10.1016/j.rala.2016.08.002.

Boyte, S.P., and Wylie, B.K., 2017, Near-real-time herbaceous annual cover in the sagebrush ecosystem (June 19, 2017): U.S. Geological Survey data release, https://doi.org/10.5066/F7M32TNF.

Boyte, S.P., and Wylie, B.K., 2018, Near-real-time herbaceous annual cover in the sagebrush ecosystem, USA, July 2018: U.S. Geological Survey data release, https://doi.org/10.5066/P9RIV03D.

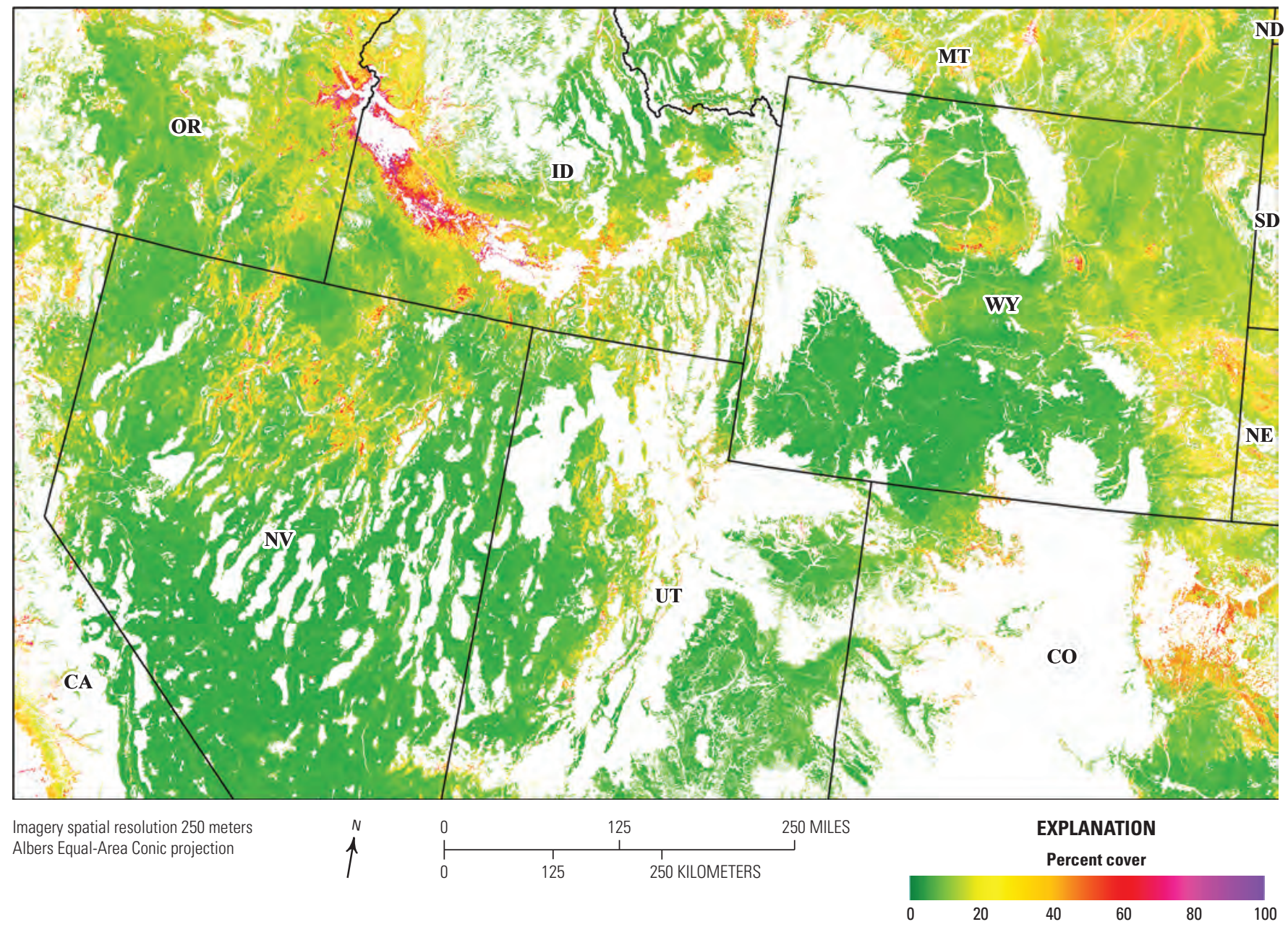

Distribution of cheatgrass and other annual herbaceous plants in 2018. 


\section{Cheatgrass Dynamics in the Northern Great Basin}

Remote sensing technologies are used to effectively monitor terrestrial vegetation globally, including cheatgrass in the northern Great Basin (NGB). Future climate scenarios forecast that the NGB will experience increased temperatures and altered timing and total amount of precipitation, changes which will alter cheatgrass dynamics. Using near-real-time cheatgrass mapping products, USGS scientists are examining the potential climate-mediated changes in future cheatgrass dynamics. Future cheatgrass percent cover may be influenced by multiple mitigating factors including changes in precipitation timing and totals and freeze-thaw cycles. Understanding the effects of these factors can help direct land management activities meant to improve control of cheatgrass.

\section{Contact}

Bruce K. Wylie, USGS Earth Resources Observation and Science Center; wylie@usgs.gov; 605-594-6078

\section{Publications}

Boyte, S.P., Wylie. B.K., and Major, D.J., in press, Validating a time series of annual grass percent cover in the sagebrush ecosystem: Rangeland Ecology \& Management.

Boyte, S.P., Wylie, B.K., Rigge, M.B., and Dahal, D., 2018, Fusing MODIS with Landsat 8 data to downscale weekly normalized difference vegetation index estimates for central Great Basin rangelands, USA: GIScience \& Remote Sensing, v. 55, no. 3, p. 376-399, https://doi.org/ 10.1080/15481603.2017.1382065.

Pastick, N.J., Wylie, B.K., and Wu, Z., 2018, Spatiotemporal analysis of Landsat- 8 and Sentinel-2 data to support monitoring of dryland ecosystems: Remote Sensing, v. 10, no. 5, article 791, 15 p., https://doi.org/10.3390/rs10050791.

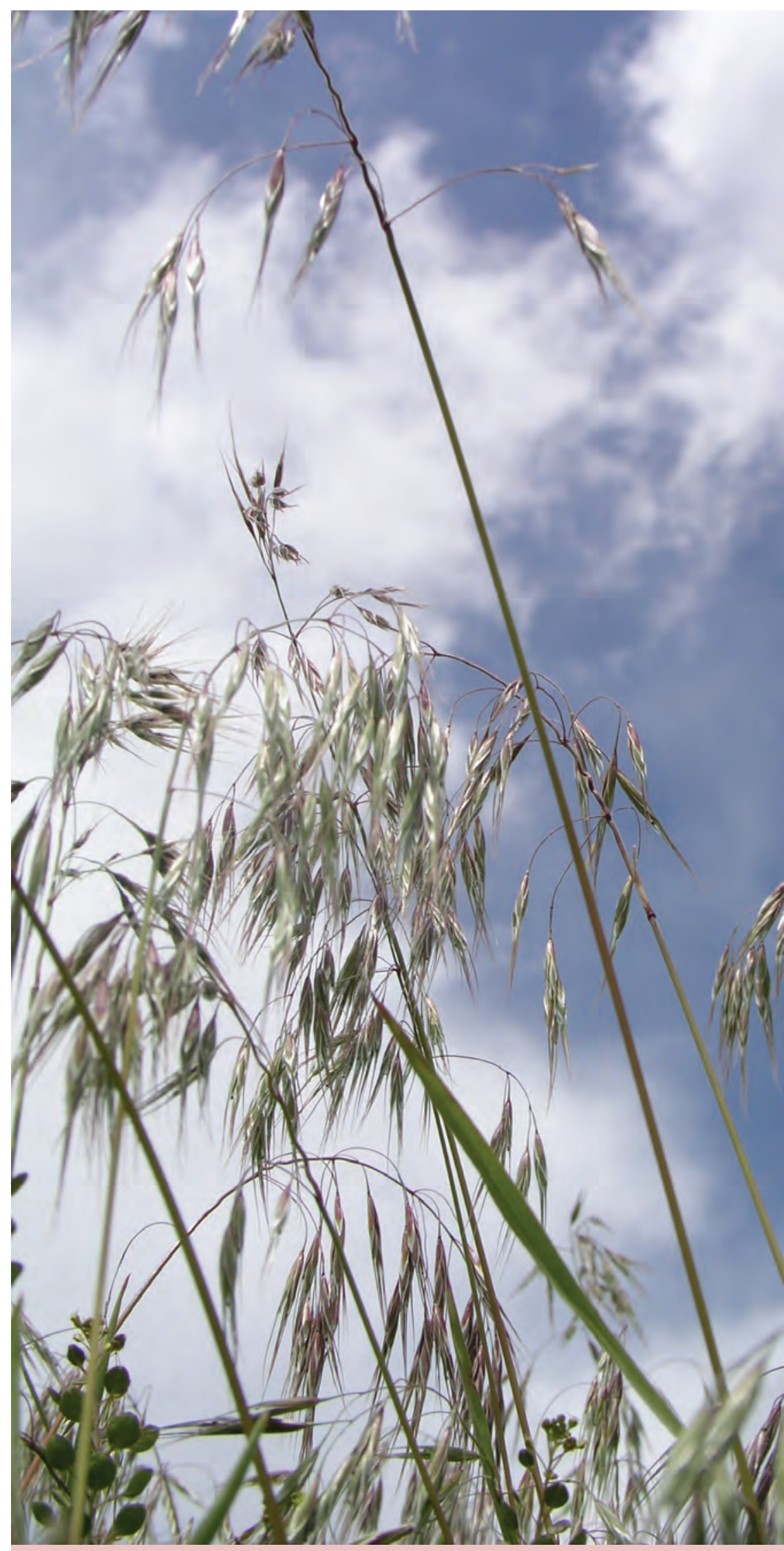

Cheatgrass. Photograph by Scott Shaff, U.S. Geological Survey. 


\section{Sagebrush Ecosystem Management in Light of Sage-Grouse, Fire, and Invasive Species}

Scientists from the USGS, with Federal and State agency collaborators, have produced a tool to help management agencies prioritize regional-scale management actions while maximizing conservation effectiveness. A strategic approach was developed for conservation and restoration of sagebrush ecosystems and sage-grouse that focuses specifically on habitat threats caused by invasive annual grasses and altered fire regimes. The tool uses information about (1) factors that influence sagebrush ecosystem resilience to disturbance and resistance to invasive annual grasses and (2) the distribution, relative abundance, and persistence of sage-grouse populations to help develop management strategies at both landscape and site scales. The tool, and associated technical reports and publications, may help managers determine the most effective management strategies based on an area's resilience to disturbance and resistance to nonnative invasive plants, particularly invasive annual grasses.

\section{Contact}

David A. Pyke, USGS Forest and Rangeland Ecosystem Science Center; david_a_pyke@usgs.gov; 541-750-0989

\section{Publications}

Chambers, J.C., Beck, J.L., Bradford, J.B., Bybee, J., Campbell, S., Carlson, J., Christiansen, T.J., Clause, K.J., Collins, G., Crist, M.R., Dinkins, J.B., Doherty, K.E., Edwards, F., Espinosa, S., Griffin, K.A., Griffin, P., Haas, J.R., Hanser, S.E., Havlina, D.W., Henke, K.F., Hennig, J.D., Joyce, L.A., Kilkenny, F.M., Kulpa, S.M., Kurth, L.L., Maestas, J.D., Manning, M., Mayer, K.E., Mealor, B.A., McCarthy, C., Pellant, M., Perea, M.A., Prentice, K.L., Pyke, D.A., Wiechman, L.A., and Wuenschel, A., 2017, Science framework for conservation and restoration of the sagebrush biome-Linking the Department of the Interior's Integrated Rangeland Fire Management Strategy to long-term strategic conservation actions; Part 1. Science basis and applications: U.S. Department of Agriculture, Forest Service, Rocky Mountain Research Station, General Technical Report RMRS-GTR-360, 213 p., https://www.treesearch.fs.fed.us/pubs/53983.

Chambers, J.C., Beck, J.L., Campbell, S., Carlson, J., Christiansen, T.J., Clause, K.J., Dinkins, J.B., Doherty, K.E., Griffin, K.A., Havlina, D.W., Henke, K.F., Hennig, J.D., Kurth, L.L., Maestas, J.D., Manning, M., Mayer, K.E., Mealor, B.A., McCarthy, C., Perea, M.A., and Pyke, D.A., 2016, Using resilience and resistance concepts to manage threats to sagebrush ecosystems, Gunnison sage-grouse, and greater sage-grouse in their eastern range-A strategic multi-scale approach: U.S. Department of Agriculture, Forest Service, Rocky Mountain Research Station, General Technical Report RMRS-GTR-356, 143 p., https://www.treesearch.fs.fed.us/pubs/53201.

Chambers, J.C., Maestas, J.D., Pyke, D.A., Boyd, C.S., Pellant, M., and Wuenschel, A., 2017, Using resilience and resistance concepts to manage persistent threats to sagebrush ecosystems and greater sage-grouse: Rangeland Ecology \& Management, v. 70, no. 2, p. 149-164, https://doi.org/10.1016/j.rama.2016.08.005.

Chambers, J.C., Pyke, D.A., Maestas, J.D., Pellant, M., Boyd, C.S., Campbell, S.B., Espinoza, S., Havlina, D.W., Mayer, K.E., and Wuenschel, A., 2014, Using resistance and resilience concepts to reduce impacts of invasive annual grasses and altered fire regimes on the sagebrush ecosystem and greater sage-grouse-A strategic multi-scale approach: U.S. Department of Agriculture, Forest Service, Rocky Mountain Research Station, General Technical Report RMRS-GTR-326, 73 p., https://www.treesearch.fs.fed.us/pubs/46329.

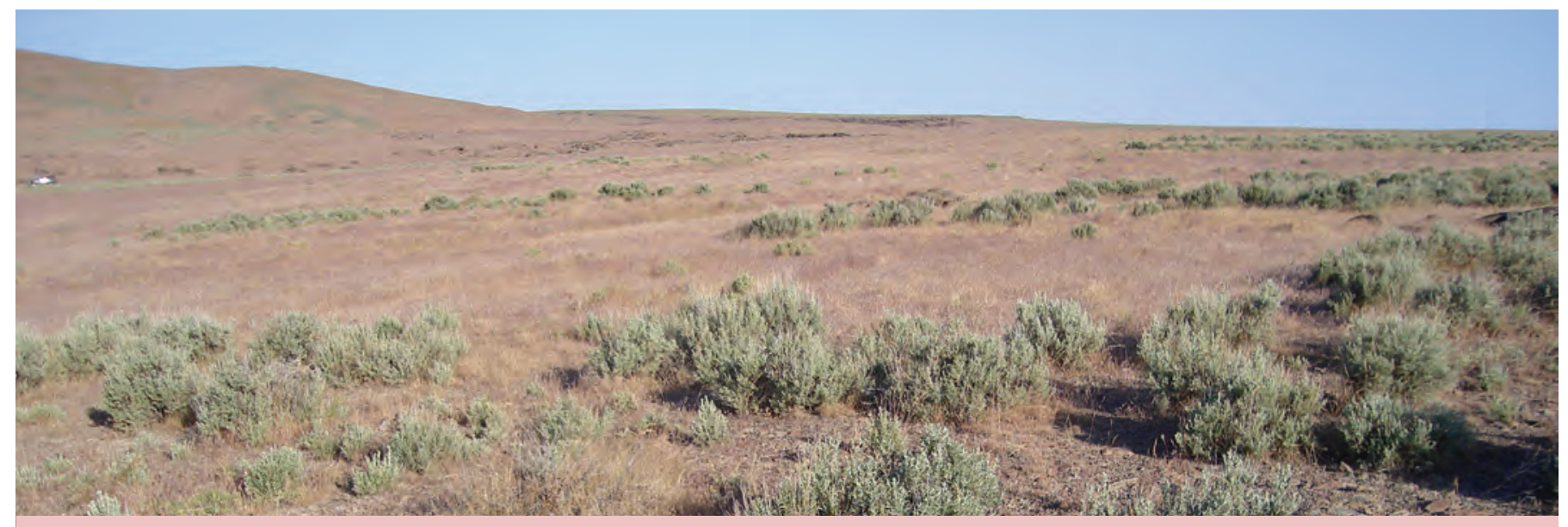

Landscape invaded by cheatgrass in southern Idaho. Photograph by Steven Hanser, U.S. Geological Survey. 


\section{Spatial Variation in the Role of Climatic Extremes in Shaping Plant Invasions}

A broad-scale perspective is needed to link geographic variation in climate and disturbance to decisions on the ground regarding where to apply treatments aimed at limiting the impacts of invasions and restoring native plant composition. USGS scientists are conducting analyses to link the abundance of major plant invaders to climatic extremes, land use, and fire history. The researchers are determining how the drivers and limits of invader abundance vary among invasive species and across the Great Basin and Mojave Desert. For example, they will examine if cheatgrass is likely to be limited by drought and temperature extremes, and whether those areas are vulnerable to red brome (Bromus rubens) invasion. The work will inform management by providing a nuanced spatial perspective on invasion risk for current and potential invaders.

\section{Contacts}

Helen Sofaer, USGS Fort Collins Science Center; hsofaer@usgs.gov; 970-226-9173

Catherine Jarnevich, USGS Fort Collins Science Center; jarnevichc@usgs.gov; 970-226-9439

\section{Exotic Forbs in Disturbed Sagebrush Steppe}

Invasion by exotic tap-rooted forbs, such as spotted knapweed (Centaurea stoebe), leafy spurge (Euphorbia esula), thistles, or skeletonweed (Chondrilla juncea), stresses big sagebrush communities, especially at higher elevations. USGS scientists have completed nearly a decade of evaluation of plant community patterns that reveal inverse relationships of exotic forbs (or deeprooted native herbs) and big sagebrush. They are also examining the ecophysiological and hydrological mechanisms underlying the competition between these exotic and native species. These exotic forbs are often secondary invaders of areas already overtaken by exotic annual grasses. When present in the landscape, exotic forbs may increase appreciably following herbicide treatments aimed at controlling annual grasses. Studies are underway to evaluate the response of exotic forbs to postfire herbicide and other land treatments. This information is intended to help managers as they work to develop alternative control strategies for exotic forbs.

\section{Contact}

Matthew J. Germino, USGS Forest and Rangeland Ecosystem Science Center; mgermino@usgs.gov; 208-426-3353

\section{Landscape-Scale Assessment of Emerging Techniques for Controlling Exotic Annual Grasses}

Invasive annual grasses such as cheatgrass and medusahead (Taeniatherum caput-medusae) lead to increased fire frequency and loss of sagebrush steppe habitat and impede restoration of desirable perennials. Weedsuppressive bacteria (WSB) are an emerging tool for selectively reducing annual grasses, but this use has not been tested well in the field. USGS scientists and collaborators are comparing commercially available sources of WSB with and without herbicides and other common postfire plant and soil treatments following fires that spanned southwestern Idaho in 2016. This research will determine if WSB are effective on target (exotic) and nontarget (native) species and will describe how to best apply WSB to help outreach specialists and land managers be best informed about the potential benefits and risks of WSB.

\section{Contact}

Matthew J. Germino, USGS Forest and Rangeland Ecosystem Science Center; mgermino@usgs.gov; 208-426-3353

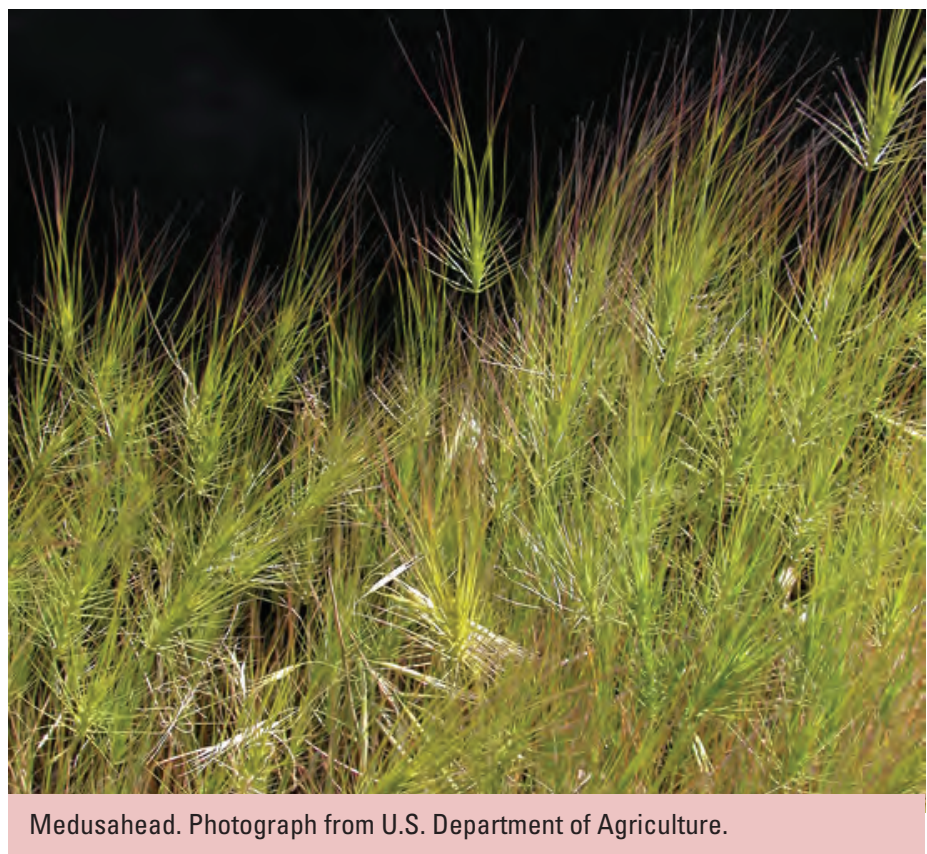




\section{Use of Cheatgrass-Suppressive Bacteria To Restore Sagebrush Steppe}

There are multiple reasons for using successful WSB that attack invasive annual grasses (particularly cheatgrass) of the Western United States and leave native perennial plants intact. USGS scientists and colleagues are using WSB (Pseudomonas fluorescens, strain D7) in two case studies at the Hanford Reach National Monument to examine these potential uses. WSB could be applied proactively to remaining sagebrush habitats that also have cheatgrass to "stop the bleeding," increasing resistance to further invasion while retaining existing native sagebrush steppe plant communities. WSB could be applied to sagebrush understories, reducing cheatgrass fuel loads, which would reduce fire risk and rate of spread. Finally, WSB could be a cost-effective means to modify the seeding environment, boosting success in postfire rehabilitation projects through reducing annual grass competition with native seedlings. This could be done without the negative impacts to native plants that have been observed with the use of herbicides.

\section{Contact}

David A. Pyke, USGS Forest and Rangeland Ecosystem Science Center; david_a_pyke@usgs.gov; 541-750-0989

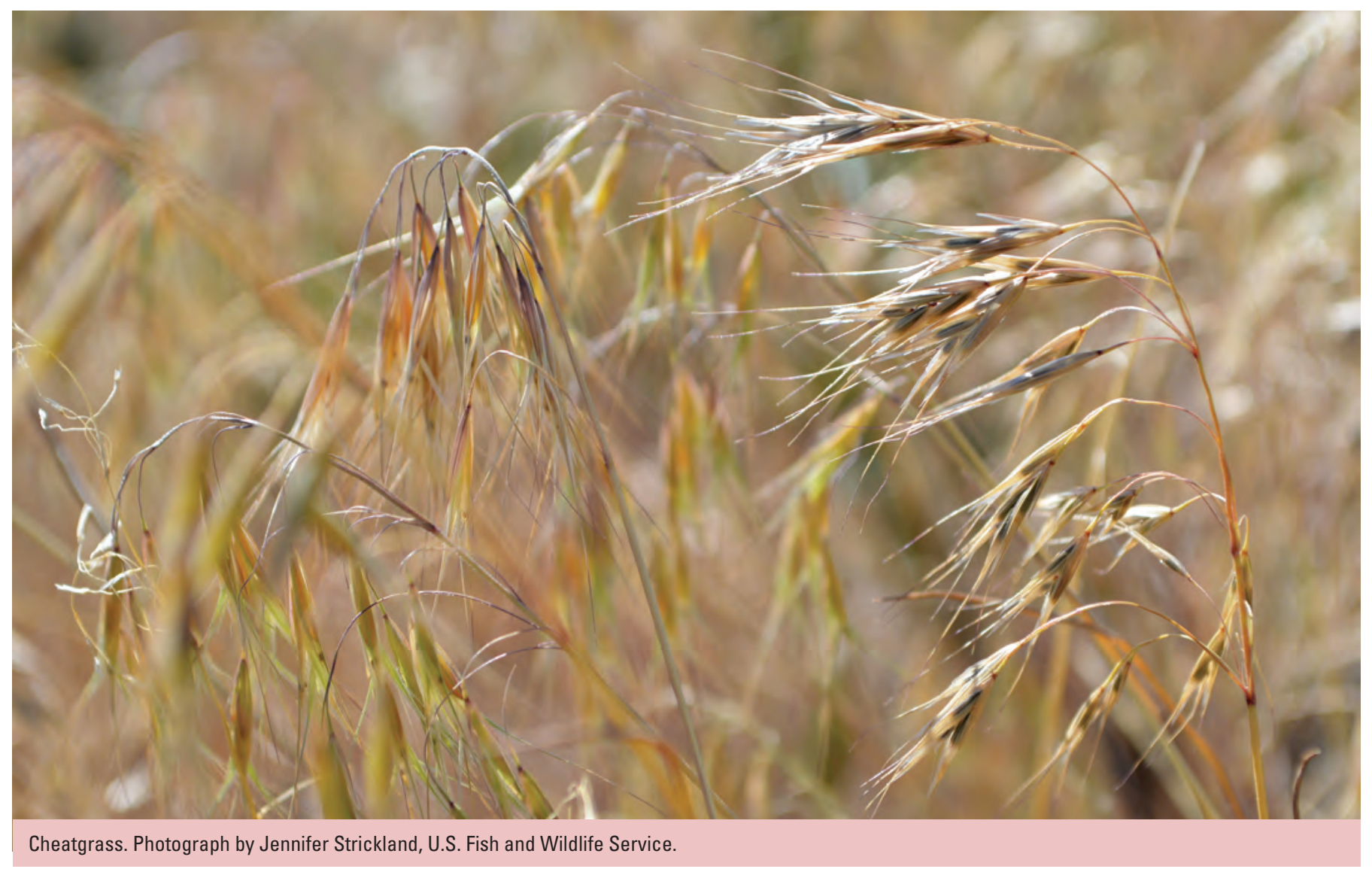

\section{Evaluating a Novel Biopesticide for Controlling Exotic Annual Grasses Following Rangeland Wildfire}

Invasions by exotic annual grasses, most notably cheatgrass and medusahead, are unambiguous threats to rangelands in the Western United States, diminishing livestock productivity and increasing wildfire activity. In a new study, USGS scientists will test the effectiveness of a novel WSB known as MB906 combined with the herbicide imazapic on target weeds and nontarget native plants on over 1,000 acres in the Boise River Wildlife Management Area, Idaho. Study plots burned in the summer of 2016, and researchers will compare untreated, control areas to areas treated with WSB, imazapic, or the combination of WSB and imazapic. The objective is to determine if, when, and where spraying is effective for controlling exotic annual grasses.

\section{Contact}

Matthew J. Germino, USGS Forest and Rangeland Ecosystem Science Center; mgermino@usgs.gov; 208-426-3353 


\section{Restoration}

Restoration of sagebrush habitats following stressors, including wildfire, invasive species, and numerous disturbance types, is important for maintaining the sagebrush ecosystem. USGS scientists are conducting a range of studies including assessing the efficiency and effectiveness of restoration actions and determining factors that increase their success. 


\section{Field of Sagebrush Dreams: Sage-Grouse Responses to Burns and Sagebrush Restoration in Fire-Affected Landscapes}

Fire can reduce sage-grouse habitat, diminish local and regional population sizes, and result in the fragmentation of sagegrouse populations. Research is needed to identify the best ways to restore sagebrush to support sage-grouse demography, persistence, and space use. To evaluate the efficacy of sagebrush restoration approaches that may create functional sage-grouse habitat in postfire landscapes, USGS and CSU scientists are (1) planting sagebrush in burned areas previously occupied by sage-grouse, (2) measuring sagebrush regrowth, (3) evaluating the use of revegetated areas by sage-grouse, and (4) quantifying the success of sage-grouse using revegetated habitat. This research will identify testable "ideal" sagebrush restoration approaches, experimenting with patch size, configuration, and proximity to edge of burn. This research will evaluate sagebrush restoration approaches, and predict times to sagebrush and sage-grouse recovery.

\section{Contacts}

Cameron L. Aldridge, Colorado State University, in cooperation with USGS Fort Collins Science Center; aldridgec@usgs.gov; 970-226-9433

David A. Pyke, USGS Forest and Rangeland Ecosystem Science Center; david_a_pyke@usgs.gov; 541-750-0989

Peter S. Coates, USGS Western Ecological Research Center; pcoates@usgs.gov; 530-669-5073

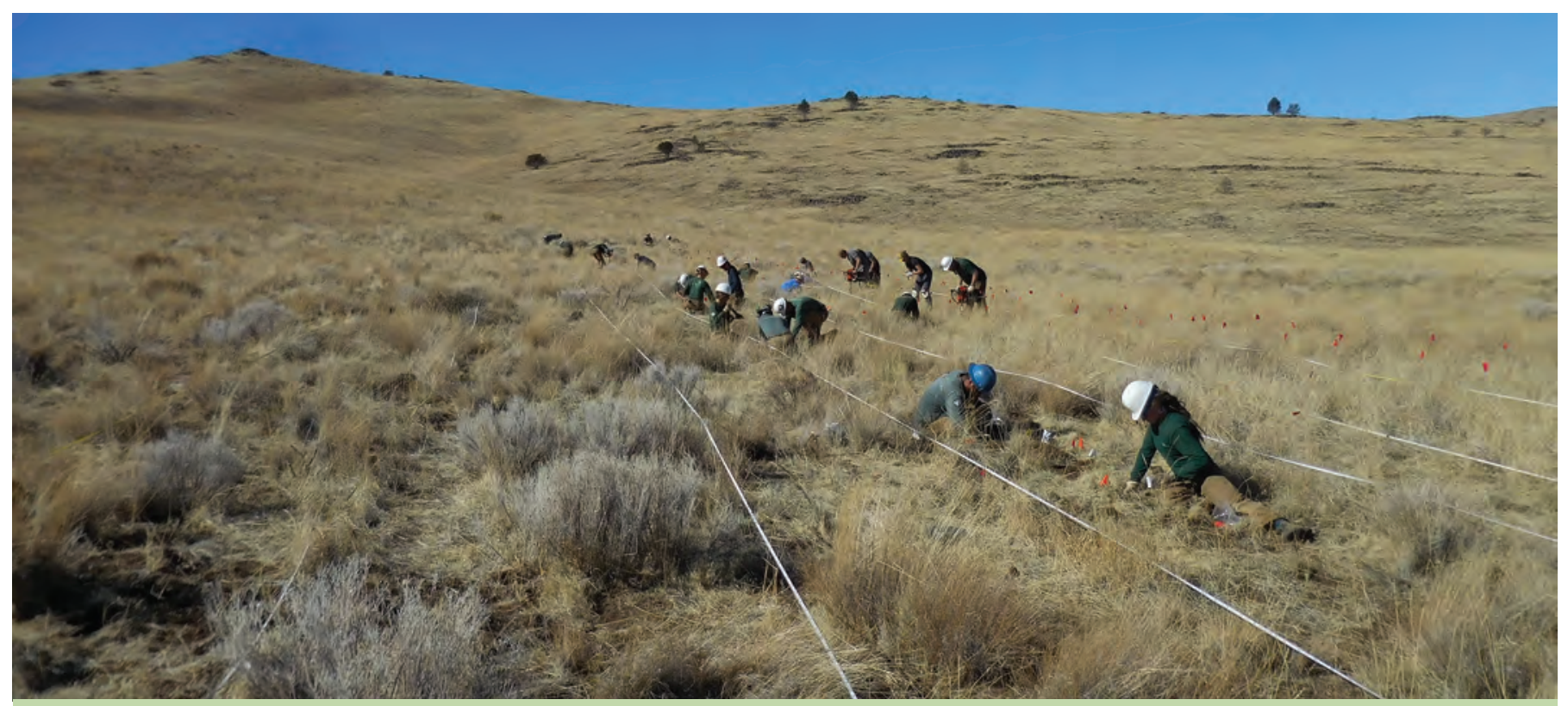

Field crew planting sagebrush seedlings in northeastern California. Photograph by David Pyke, U.S. Geological Survey.

\section{Restoration of Native Understory Plants in Degraded Sagebrush Steppe Ecosystems}

Sagebrush steppe that is resistant to annual grasses typically has herbaceous perennials between and under sagebrush and other shrubs. When fires burn these resistant communities, they may eliminate sagebrush temporarily, but these understory plants may survive and compete with cheatgrass and shortly regain their codominance in the community. However, large expanses of sagebrush lands are now missing their herbaceous understory and are at risk of being dominated by annual grasses after the next fire. Current practice is to wait for fires to eliminate sagebrush before attempting restoration, but transplanting herbaceous understory plants into vacant gaps before the next fire may successfully increase resistance of these communities. USGS scientists are evaluating transplants and seeding for reintroducing native grasses and forbs into interspaces between shrubs to inform future management efforts to improve sage-grouse habitat in sagebrush lands that are lacking native herbaceous plants.

\section{Contact}

David A. Pyke, USGS Forest and Rangeland Ecosystem Science Center; david_a_pyke@usgs.gov; 541-750-0989 


\section{Selecting the Right Seed for Restoration Success}

Sagebrush ecosystems are threatened by an increasing number of large wildfires because sagebrush cannot re-sprout after a burn and natural seedling establishment is limited. Land managers attempt to recolonize sagebrush by aerial or drill seeding burned areas. Seeds used in sagebrush ecosystem restoration and rehabilitation projects often are transferred across climate zones and hundreds of miles. USGS scientists are examining how seeds from different climates and with different genetic characteristics grow in variable climates and respond to traditional seeding treatments. They are determining how seeds of sagebrush and key native perennial species from different sources grow, survive, and respond to different temperature and precipitation patterns and to the planting methods managers traditionally employ. This information will inform agency seed procurement and provide postfire rehabilitation specialists with the basic information needed to use "the right seed in the right place at the right time."

\section{Contact}

Matthew J. Germino, USGS Forest and Rangeland Ecosystem Science Center; mgermino@usgs.gov; 208-426-3353

\section{Publications}

Brabec, M.M., Germino, M.J., and Richardson, B.A., 2017, Climate adaption and post-fire restoration of a foundational perennial in cold desert - Insights from intraspecific variation in response to weather: Journal of Applied Ecology, v. 54, no. 1, p. 293-302, https://doi.org/10.1111/1365-2664.12679.

Chaney, L., Richardson, B.A., and Germino, M.J., 2017, Climate drives adaptive genetic responses associated with survival in big sagebrush (Artemisia tridentata): Evolutionary Applications, v. 10, no. 4, p. 313-322, https://doi.org/10.1111/eva.12440.

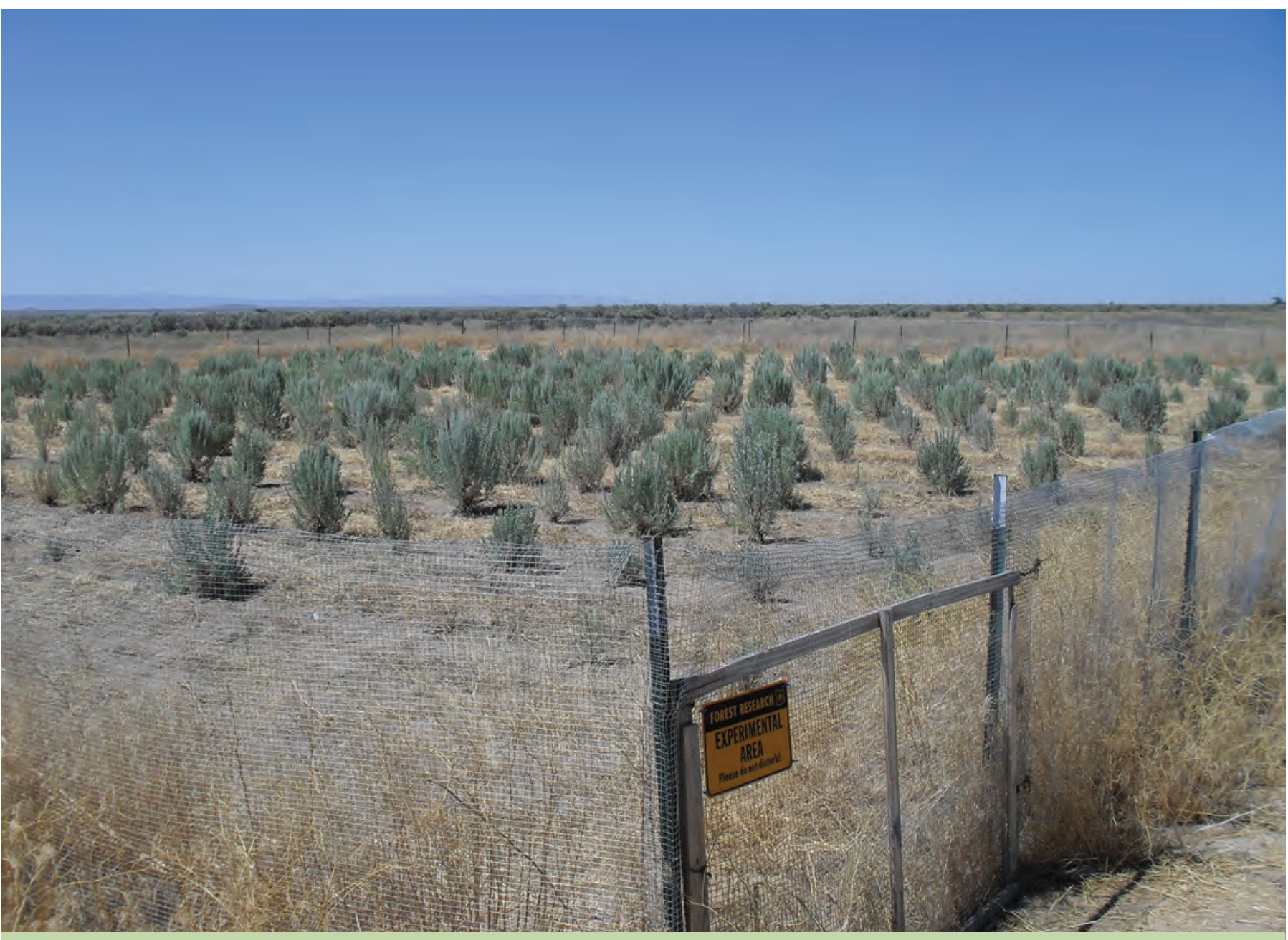




\section{SageSuccess Project: Sagebrush Restoration for Sage-Grouse}

The SageSuccess Project is a joint effort among the USGS, BLM, and U.S. Fish and Wildlife Service (FWS) to examine the factors that contribute to establishment of big sagebrush across the range of the sage-grouse and whether seeding and planting sagebrush ultimately creates high-quality sage-grouse habitat. Scientists will examine seedings and plantings completed between 1990 and 2013 to assess factors including seed subspecies and source, climate, soil type and moisture, fire history, land use, and treatment implementation method. Where seed sources are known, researchers will assess the effects of seed transfer across geographic, elevation, and climate zones on seeding outcomes. This research will inform site-level management activities and explore new practices or improvements of existing methods to restore sagebrush.

\section{Contacts}

David S. Pilliod, USGS Forest and Rangeland Ecosystem Science Center; dpilliod@usgs.gov; 208-426-5202

John B. Bradford, USGS Southwest Biological Science Center; jbradford@usgs.gov; 928-523-7766

\section{Publications}

Germino, M.J., Barnard, D.M., Davidson, B.E., Arkle, R.S., Pilliod, D.S., Fisk, M.R., and Applestein, C., 2018, Thresholds and hotspots for shrub restoration following a heterogeneous megafire: Landscape Ecology, v. 33, no. 7, p. 1177-1194, https://doi.org/10.1007/s10980-018-0662-8.

Shriver, R.K., Andrews, C.M., Pilliod, D.S., Arkle, R.S., Welty, J.L., Germino, M.J., Duniway, M.C., Pyke, D.A., and Bradford, J.B., 2018, Adapting management to a changing world-Warm temperatures, dry soil, and inter-annual variability limit restoration success of a dominant woody shrub in temperate drylands: Global Change Biology, Early View article posted July 2, 2018, 12 p., https://doi.org/10.1111/gcb.14374.

\section{Assessing the Influence of Microsite Soil Characteristics on Sagebrush Restoration Success}

Fertile "islands" are important for germination, growth, and establishment of sagebrush and other plants in arid and semiarid environments because of the unique soil nutrients and microclimates they provide. In recently burned areas, these microsites are often associated with locations of former sagebrush plants. USGS scientists have observed big sagebrush seedling establishment in these fertile islands 1 year after fire, and sometimes these were the only locations where young sagebrush was thriving. The researchers are currently broadening the inference of these observations by sampling additional recently burned sites across the Great Basin to determine (1) whether this pattern holds, (2) what soil characteristics lead to this pattern, and (3) whether these soil characteristics could be reproduced by manipulating postfire soils in areas that have no prefire sagebrush. This work could help inform future big sagebrush seeding efforts.

\section{Contact}

David S. Pilliod, USGS Forest and Rangeland Ecosystem Science Center; dpilliod@usgs.gov; 208-426-5202

\section{Soda Wildfire Response: Integrating Science Into Adaptive Management}

The "Integrated Rangeland Fire Management Strategy" provides a comprehensive, science-based approach to enhance the conservation and restoration of the sagebrush steppe and to meet important economic, cultural, and social goals. The management response to the 2015 Soda Wildfire, which burned 285,000 acres of mostly sagebrush steppe in the northern Great Basin, is the first test of new guidelines outlined in the strategy. Managers used herbicide applications and planted or seeded desirable species to restore site resistance and resilience and habitats of sagebrush-obligate species. The USGS is leading the effort to monitor these vegetation treatments to (1) inform retreatment decisions, (2) determine when to allow resumption of grazing, (3) report on site recovery and treatment effectiveness, and (4) provide a comprehensive assessment of a major fire rehabilitation project in sagebrush steppe. Resulting data will be useful for testing theories about resistance and resilience, the role of bunchgrasses, exotic annual grass responses, sagebrush seed source effects, soil stability effects, and how management actionsparticularly iterative treatments - impact these variables.

\section{Contact}

Matthew J. Germino, USGS Forest and Rangeland Ecosystem Science Center; mgermino@usgs.gov; 208-426-3353 


\section{Publications}

Applestein, C., Germino, M.J., and Fisk, M.R., in press, Vegetative community response to landscape scale post-fire herbicide (Imazapic) application: Invasive Plant Science and Management, https://doi.org/10.1017/inp.2018.18.

Applestein, C., Germino, M.J., Pilliod, D.S., Fisk, M.R., and Arkle, R.S., 2018, Appropriate sample sizes for monitoring burned pastures in sagebrush steppe-How many plots are enough, and can one size fit all?: Rangeland Ecology \& Management, Corrected Proof posted June 13, 2018, https://doi.org/10.1016/j.rama.2018.05.003.

Germino, M.J., Barnard, D.M., Davidson, B.E., Arkle, R.S., Pilliod, D.S., Fisk, M.R., and Applestein, C., 2018, Thresholds and hotspots for shrub restoration following a heterogeneous megafire: Landscape Ecology, v. 33, no. 7, p. 1177-1194, https://doi.org/10.1007/s10980-018-0662-8.

\section{Modeling Recovery of Sagebrush Ecosystems Using Remote Sensing Products}

The ability to predict sagebrush recovery following disturbance is limited by a paucity of research quantifying the spatial and temporal factors influencing recovery across landscapes. USGS and CSU scientists are developing a framework for modeling changes in sagebrush cover on reclaimed well pads using time-varying remote sensing products developed for the Wyoming Landscape Conservation Initiative (WLCI) to model rates of change in sagebrush and bare ground cover at 2- to 5-year intervals from 1991 through 2015. This approach allows the prediction of rates of recovery across broad landscapes and assessment of effects of factors such as weather and soils on outcomes. This approach is now being extended to the rest of Wyoming and the Great Basin and examining trends in vegetation following other disturbance such as fire and land treatments.

\section{Contacts}

Cameron L. Aldridge, Colorado State University, in cooperation with USGS Fort Collins Science Center; aldridgec@usgs.gov; 970-226-9433

Adrian P. Monroe, Colorado State University, in cooperation with USGS Fort Collins Science Center; amonroe@usgs.gov; 970-226-9122

\section{Improving Sagebrush Ecosystem Resistance and Resilience To Inform Conservation}

Resistance and resilience concepts provide an important framework for sagebrush habitat management. Existing spatial products have been developed using Natural Resources Conservation Service (NRCS) soil data; models using new data and methods can improve these products. USGS scientists are using information on soils, climate, solar radiation, and daily snowmelt to develop new continuous estimates of seasonal moisture balances and refined soil temperature and moisture regime estimates. Enhancements will account for temporal lags of water release, modified temperature, seasonal moisture budgets, and refinements of moisture-temperature regimes. These results will provide enhanced understanding of historic and future conditions that may influence the distribution of invasive plants and invasion risk, the distribution and dynamics of sagebrush, and recovery rates.

\section{Contacts}

Daniel J. Manier, USGS Fort Collins Science Center; manierd@usgs.gov; 970-226-9466

Michael O'Donnell, USGS Fort Collins Science Center; odonnellm@usgs.gov; 970-226-9407

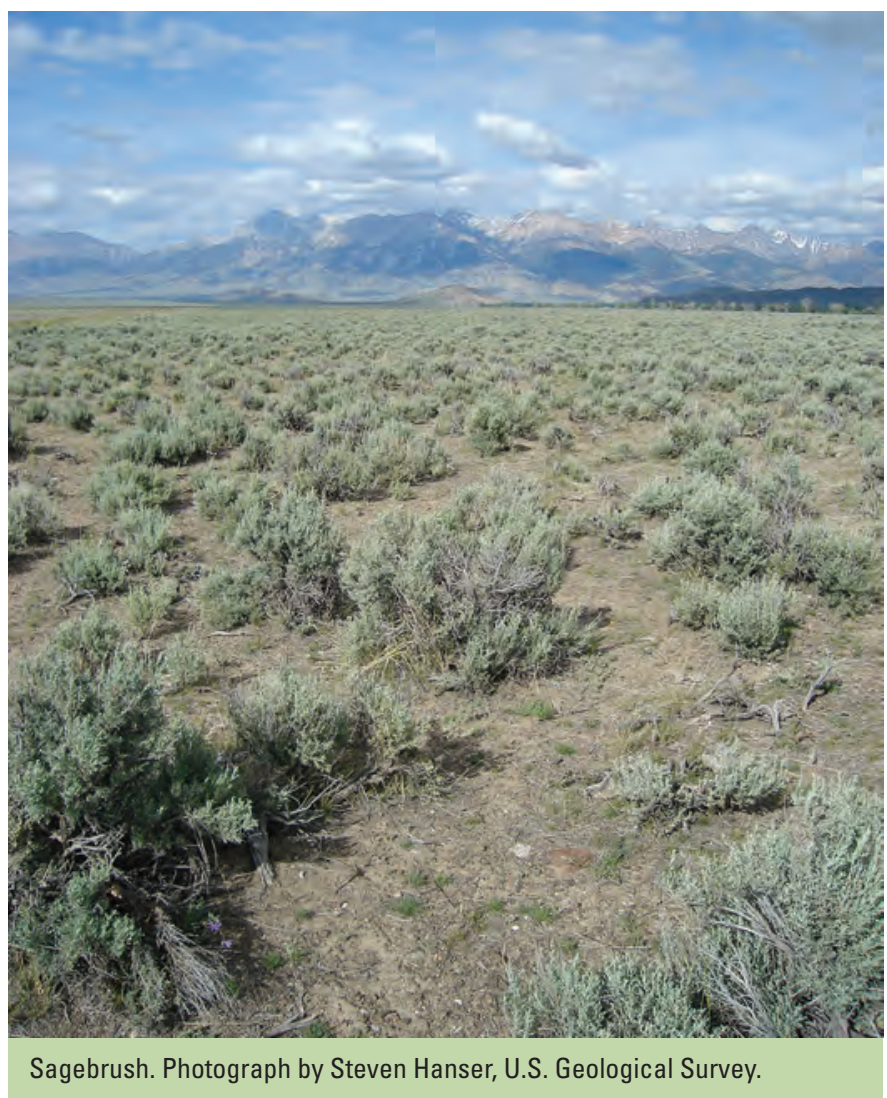




\section{Postfire Sagebrush Growth}

Establishment and growth of big sagebrush after fire are critical components of restoration efforts in the Great Basin; however, these ecological processes often occur over several decades and thus are difficult to document. In the northern Great Basin, a number of postfire restoration vegetation surveys conducted between 5 and 25 years ago provide an opportunity to revisit and measure these vegetation characteristics. The goal of these remeasurement surveys is to quantify how growth of big sagebrush after fire influences habitat of greater sage-grouse through changes in density, cover, and height. USGS researchers are also assessing how sagebrush growth influences cover of exotic annuals, especially cheatgrass, and native forbs. Comparisons between growth rates of seeded and planted (that is, nursery-raised seedlings) will be made. Results may assist managers in determining the length of time and environmental conditions required for sagebrush establishment to meet sage-grouse habitat guidelines.

\section{Contact}

David S. Pilliod, USGS Forest and Rangeland Ecosystem Science Center; dpilliod@usgs.gov; 208-426-5202

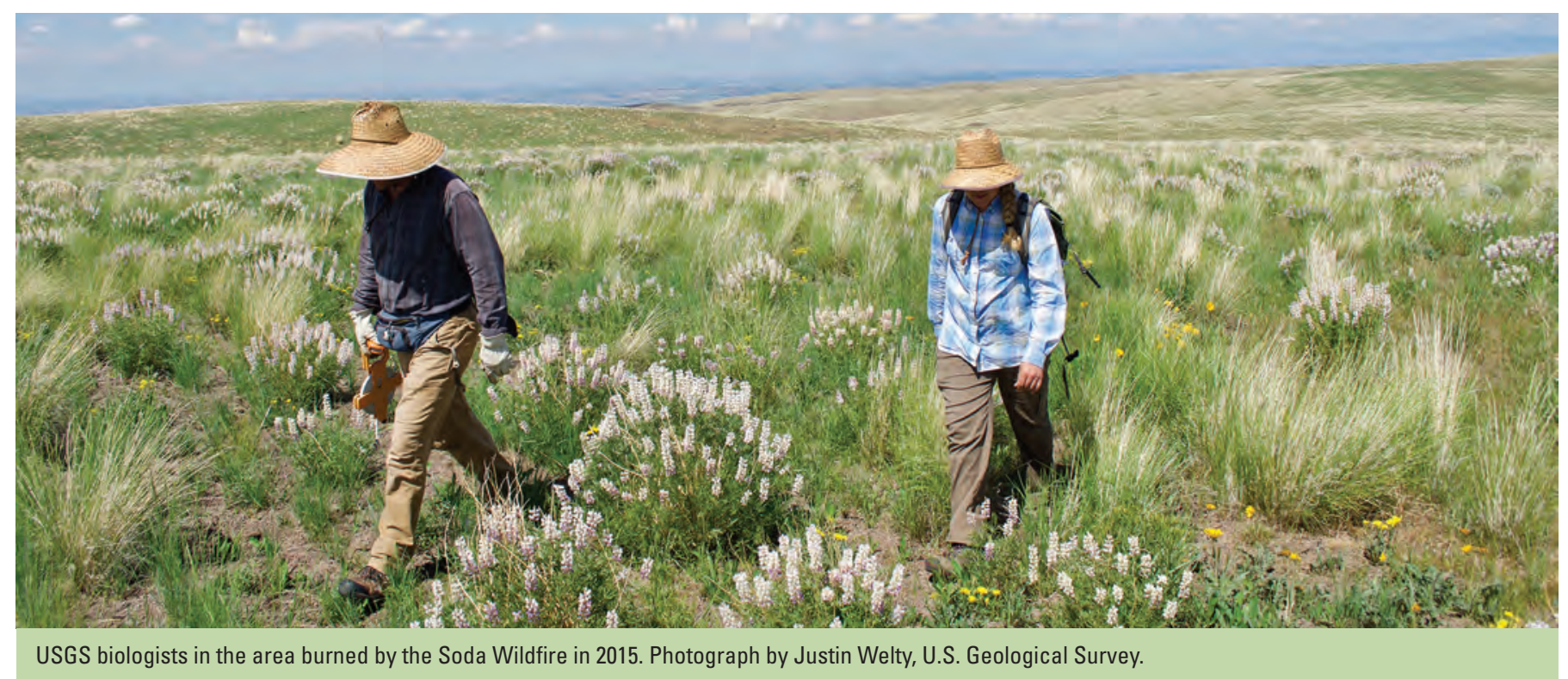

\section{Land Treatment Digital Library}

The BLM actively manages vegetation on millions of acres of public rangelands in the United States. The USGS and BLM compiled over 75 years of records of those vegetation management actions — or land treatments - into a centralized, spatially explicit database called the Land Treatment Digital Library (LTDL), which can be accessed at https://tdl.wr.usgs.gov. In a recently published paper, researchers summarized data from over 9,000 treatments in the Great Basin to highlight the scope and scale of information in the LTDL. The authors discussed how this information can be used for adaptive management and ecological research, including evaluating responses of communities and ecosystems to natural and human caused disturbance. Information in the LTDL can help land managers evaluate past treatments and improve future restoration actions.

\section{Contact}

David S. Pilliod, USGS Forest and Rangeland Ecosystem Science Center; dpilliod@usgs.gov; 208-426-5202

\section{Publications}

Copeland, S.M., Munson, S.M., Pilliod, D.S., Welty, J.L., Bradford, J.B., and Butterfield, B.J., 2018, Long-term trends in restoration and associated land treatments in the southwestern United States: Restoration Ecology, v. 26, no. 2, p. 311-322, https://doi.org/10.1111/rec.12574.

Pilliod, D.S., Welty, J.L., and Toevs, G.R., 2017, Seventy-five years of vegetation treatments on public rangelands in the Great Basin of North America: Rangelands, v. 39, no. 1, p. 1-9, https://doi.org/10.1016/j.rala.2016.12.001. 


\section{Land Treatment Decision Support Tool}

The LTDL houses information on nearly 40,000 land treatments in the Western United States. The BLM and the USGS are developing a decision support and planning tool that enables users to upload a proposed treatment area during the planning phase of a project to identify past treatments that have occurred in an area or that share similar characteristics, such as treatment types, ecological sites, seed mixes, or other factors. When queried, the tool will return both nearby treatments and treatments within a larger range that match one or more specific search attributes specified by the user. Users can then tap into this information to assess what worked where and why, and potentially network with other personnel who implemented these treatments. Ultimately, this tool will aid in planning future land treatments and implementing adaptive management strategies for improved likelihood of success for future treatments.

\section{Contact}

David S. Pilliod, USGS Forest and Rangeland Ecosystem Science Center; dpilliod@usgs.gov; 208-426-5202

\section{Publication}

Pilliod, D.S., Welty, J.L., Jeffries, M.I., Schueck, L.S., and Zarriello, T.J., 2018, Land treatment planning tool: U.S. Geological Survey Fact Sheet 2018-3042, 2 p., https://doi.org/10.3133/fs20183042.
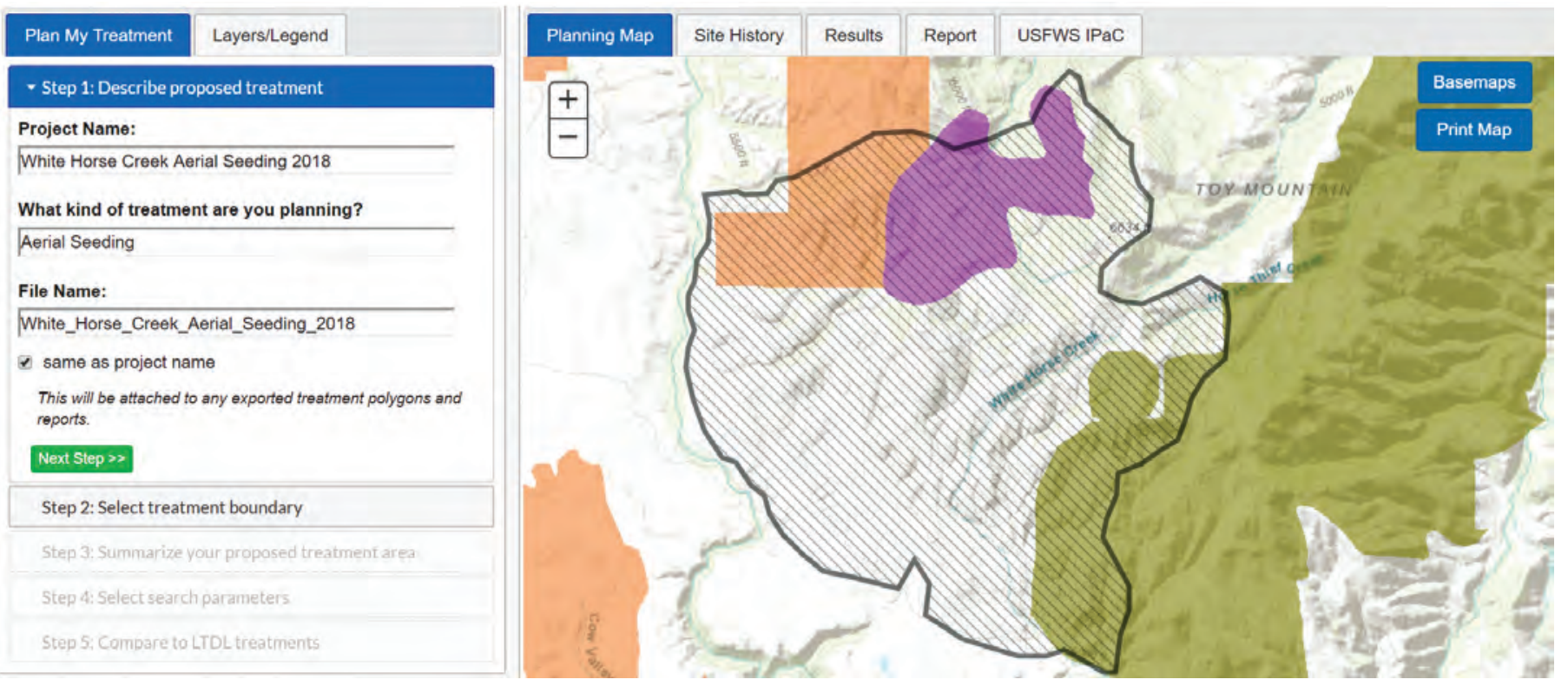

Example of the interactive map interface in the land treatment planning tool.

\section{Interpreting Indicators of Rangeland Health}

Qualitative assessments of rangeland health using observable indicators help managers make informed land management decisions and communicate findings with the public. The USGS and other Federal agencies have jointly developed a system in which 17 indicators are used to gauge three attributes of rangeland health — soil and site stability, hydrology, and biology —and created a monitoring protocol for managers to assess the functional status of rangelands and provide early warnings of resource problems. Recent revisions to the protocol reflect changes learned through 13 years of teaching and applying previous versions. The evaluation is used widely by the BLM, the NRCS, and many private rangeland consultants.

\section{Contact}

David A. Pyke, USGS Forest and Rangeland Ecosystem Science Center; david_a_pyke@usgs.gov; 541-750-0989 


\section{Publications}

Herrick, J.E., Shaver, P., Pyke, D.A., Pellant, M., Toledo, D., Lepak, N.A., in press, Strategy for defining the reference for land health and degradation assessments.

Pellant, M., Shaver, P.L., Pyke, D.A., Herrick, J.E., Busby, F.E., Riegel, G., Lepak, N., Kachergis, E., Newingham, B.A., and Toledo, D., in press, Interpreting indicators of rangeland health (ver. 5): U.S. Department of the Interior, Bureau of Land Management, National Operations Center, Denver, CO, Technical Reference 1734-6.

\section{Effectiveness of Layering Treatments in the "Multiple Intervention" Response to Wildfire in Sagebrush Steppe}

Improving postfire treatments to decrease exotic annuals and increase perennial plants is a priority science need for managers. Postfire treatments typically entail multiple interventions, such as herbicide or seeding applications, which can have reinforcing or canceling effects on treatment success. However, there is little science to guide decisions on how to order and time different treatments following fire. USGS scientists are conducting research on the 285,000 acres burned by the 2015 Soda Wildfire in southwestern Idaho to determine how different sequences of seeding and herbicide can be optimized to reduce exotics and increase perennials and how treatment effects are modulated by postfire grazing resumption. This project will help managers determine how treatments can be best phased to optimize postfire restoration outcomes.

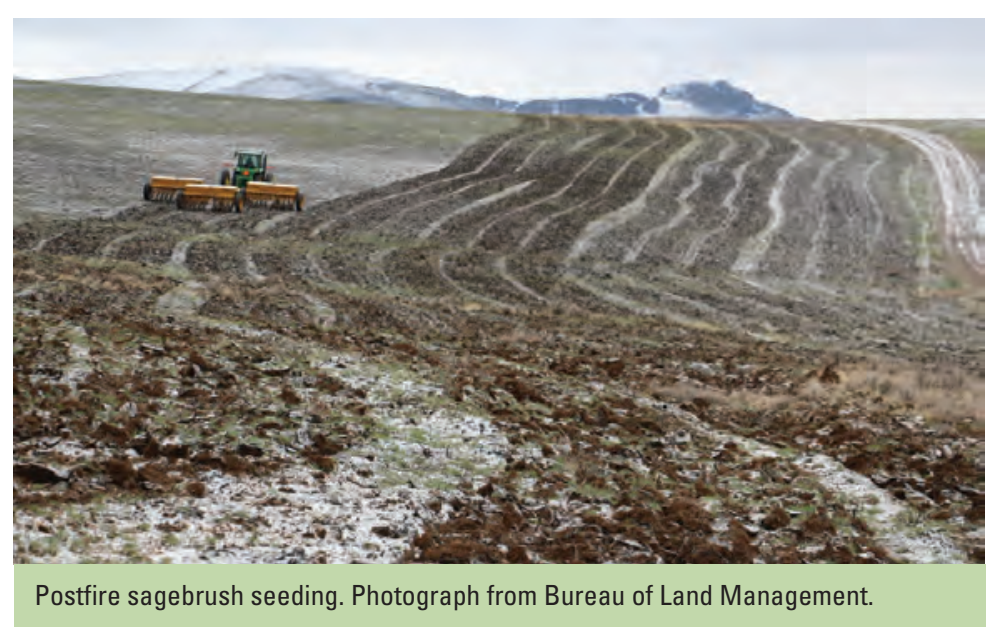

\section{Contact}

Matthew J. Germino, USGS Forest and Rangeland Ecosystem Science Center; mgermino@usgs.gov; 208-426-3353

\section{Phasing Herbicide, Drill Seeding, and Grazing Resumption in Postfire Sagebrush Steppe}

Postfire management interventions in the sagebrush steppe often combine treatments, such as applying herbicides to reduce exotic annuals or seeding desirable perennials. Phasing these various treatment types in different postfire years may optimize effects and increase a site's ability to withstand impacts of resuming livestock grazing. USGS scientists are measuring how vegetation responds to phasing of land management actions - specifically herbicide spraying, drill seeding, and resumption of grazing - in the first few years following wildfire in sagebrush steppe. They will assess the relative abundance of exotic annual and desirable perennial grasses with respect to different sequences of seeding and spraying, and determine how treatments contribute to a sites resistance, resilience, and ability to withstand grazing. This research will provide information to rangeland managers about if and how to combine and phase herbicide and seeding treatments.

\section{Contact}

Matthew J. Germino, USGS Forest and Rangeland Ecosystem Science Center; mgermino@usgs.gov; 208-426-3353

\section{Experimental Tests of Management Options for Improving Outplanting Success of Big Sagebrush}

Methods for increasing success of seeded or planted sagebrush are desired by land managers. USGS scientists are performing experimental tests of methods for improving sagebrush outplanting success, including the use of wind shelters, wattles, cluster plantings, landscape and topography strategies, and treatments of herb layers. Outcomes of this study may help provide managers with new methods for improving establishment of sagebrush in restoration treatments.

\section{Contact}

Matthew J. Germino, USGS Forest and Rangeland Ecosystem Science Center; mgermino@usgs.gov; 208-426-3353 


\section{Community Composition and Restoration of Biological Soil Crusts of Nevada's Sagebrush Steppe}

Biological soil crusts often exist in spaces between arid and semiarid plants and can improve soil stability, hydrology, nutrient cycling, and potentially the resistance of plant communities to invasive annual grasses. The USGS is leading a study to examine the extent of biological soil crusts in Nevada's sagebrush steppe and some of the potential factors influencing the absence of crusts across sagebrush ecosystems. Researchers will use existing data to find ecological sites with the potential to support biological soil crusts. Objectives include determining how soil properties, climate, livestock use, and fire affect the community composition of biological soil crusts. The resulting information will show how crusts respond to disturbances and the ecological factors that influence these important biological communities.

\section{Contact}

David A. Pyke, USGS Forest and Rangeland Ecosystem Science Center; david_a_pyke@usgs.gov; 541-750-0989

\section{Publications}

Condon, L.A., and Pyke, D.A., 2016, Filling the interspace - restoring arid land mosses; Source populations, organic matter, and overwintering govern success: Ecology and Evolution, v. 6, no. 21, p. 7623-7632, https://doi.org/10.1002/ece3.2448.

Condon, L.A., and Pyke, D.A., 2018, Fire and grazing influence site resistance to Bromus tectorum through their effects on shrub, bunchgrass and biocrust communities in the Great Basin (USA): Ecosystems, First Online article posted February 28, 2018, 16 p., https://doi.org/10.1007/ s10021-018-0230-8.

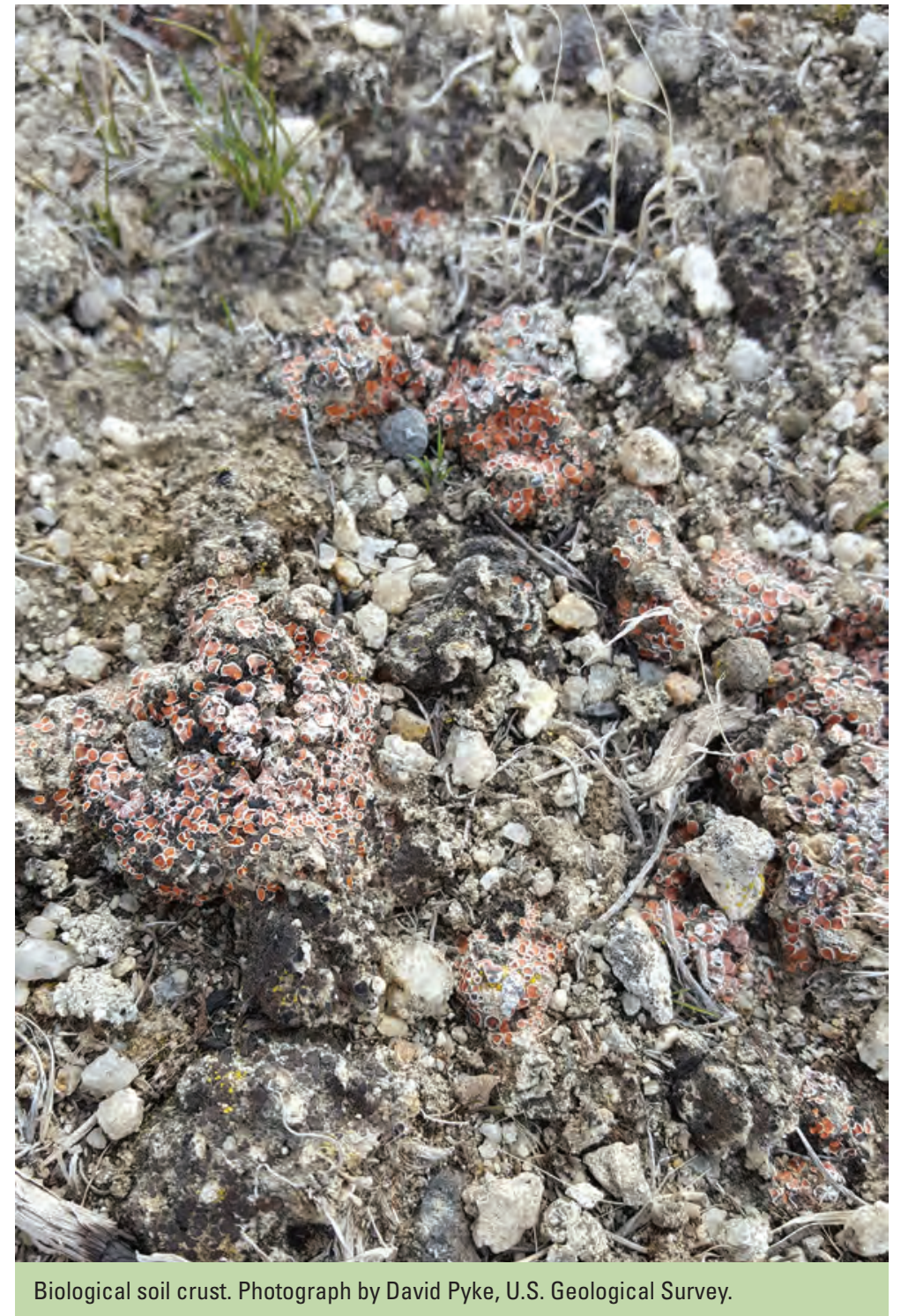

\section{Holding Their Ground: Does Biological Soil Crust Restoration Enhance the Germination of Native Plants and Reduce Soil Degradation?}

In the Great Basin, soil erosion on burned slopes can be 10 times that on unburned slopes. Additionally, revegetation projects often fail because of annual fluctuations in precipitation. Biological soil crusts, particularly mosses, can reduce soil erosion and help retain soil water, improving native plant restoration after fires. USGS scientists are experimenting with moss restoration using two stabilization methods, a jute net and a hydro-mulch tackifier, which are already used by the USDA Forest Service for soil erosion control on some burned hillslopes. They will compare the jute net against the tackifier to determine how well each method prevents soil erosion and restores mosses and native plants. They will also mimic a 25 -year-maximum storm event to determine soil erosion and water runoff. The study aims to aid Federal, State, Tribal, and private land owners throughout the Great Basin in their efforts to protect soils while restoring plants.

\section{Contact}

David A. Pyke, USGS Forest and Rangeland Ecosystem Science Center; david_a_pyke@usgs.gov; 541-750-0989 


\section{Decision Support for Conservation and Restoration Efforts in the Sagebrush Biome}

The DOI, USDA, and State agencies share common management goals for sagebrush ecosystems, including improving the capacity to manage for resistance to invasive species or resilience to disturbance to achieve long-term conservation and restoration objectives. USGS scientists along with Federal and State partners are developing a core set of data, models, and a web-based geospatial tool that provides an analytical backbone to support planning needs in the sagebrush biome. Initial efforts focus on making data and derived products associated with the "Science Framework for Conservation and Restoration of the Sagebrush Biome" (Chambers and others, 2017) available and usable by a wide audience. Key functions of the web tools include (1) spatial data discovery and exploration; (2) summarization and reporting of data by predefined geographic units at different scales; and (3) summarization, reporting, clipping, and downloading of data by user-defined areas of interest. This work is capitalizing on previous and ongoing research projects that are focused on large landscape conservation.

\section{Contact}

Zachary H. Bowen, USGS Fort Collins Science Center; bowenz@usgs.gov; 970-226-9218

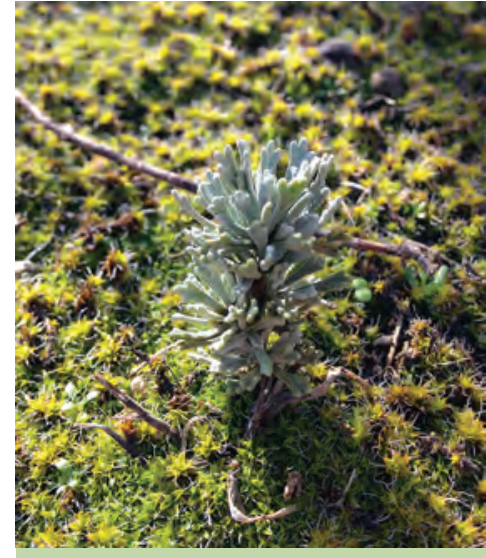

Sagebrush seedling. Photograph by Matthew Germino, U.S. Geological Survey.

\section{Bureau of Land Management Seed Warehouse Database}

The BLM National Seed Warehouse program purchases and distributes millions of pounds of seed every year for BLM and partner seeding treatments. Currently, tracking of individual seed bags and pallets is accomplished through paper documents and electronic spreadsheets. Through a collaborative process, the BLM and the USGS are working to design an online seed warehouse tracking database to store information about individual seed bags. The database will be used to enhance information collected from seed species, seed testing, seed lot, and vendors to facilitate analyses of seed germination and establishment on treatments throughout the Western United States. Analyses will provide insight on seed quality and treatment effectiveness.

\section{Contact}

David S. Pilliod, USGS Forest and Rangeland Ecosystem Science Center; dpilliod@usgs.gov; 208-426-5202

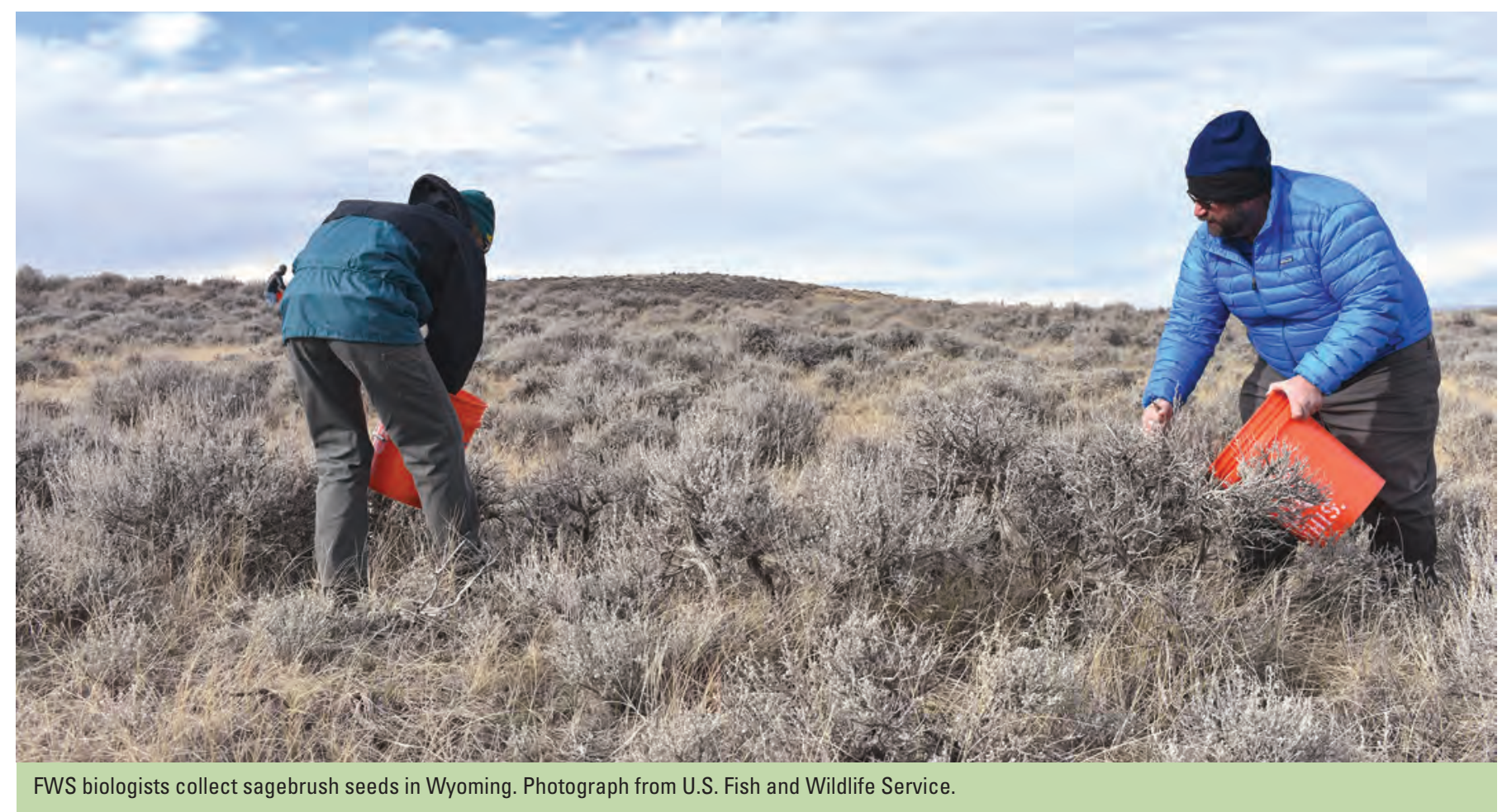




\section{Sagebrush, Sage-Grouse, and Other Sagebrush-Associated Species}

Efforts to maintain and improve conditions for sage-grouse depend on understanding the behavior, habitat use, and population structure of the species. Additionally, holistically understanding the dynamics within the sagebrush ecosystem can help land managers apply strategies to maintain the ecosystem and the plants and wildlife that depend on it. USGS scientists are conducting research to inform management of the sage-grouse and the sagebrush ecosystem, including development of sage-grouse monitoring and population analysis tools, maps of sagebrush ecosystem components, and improved ecological understanding of sagebrush-associated species.

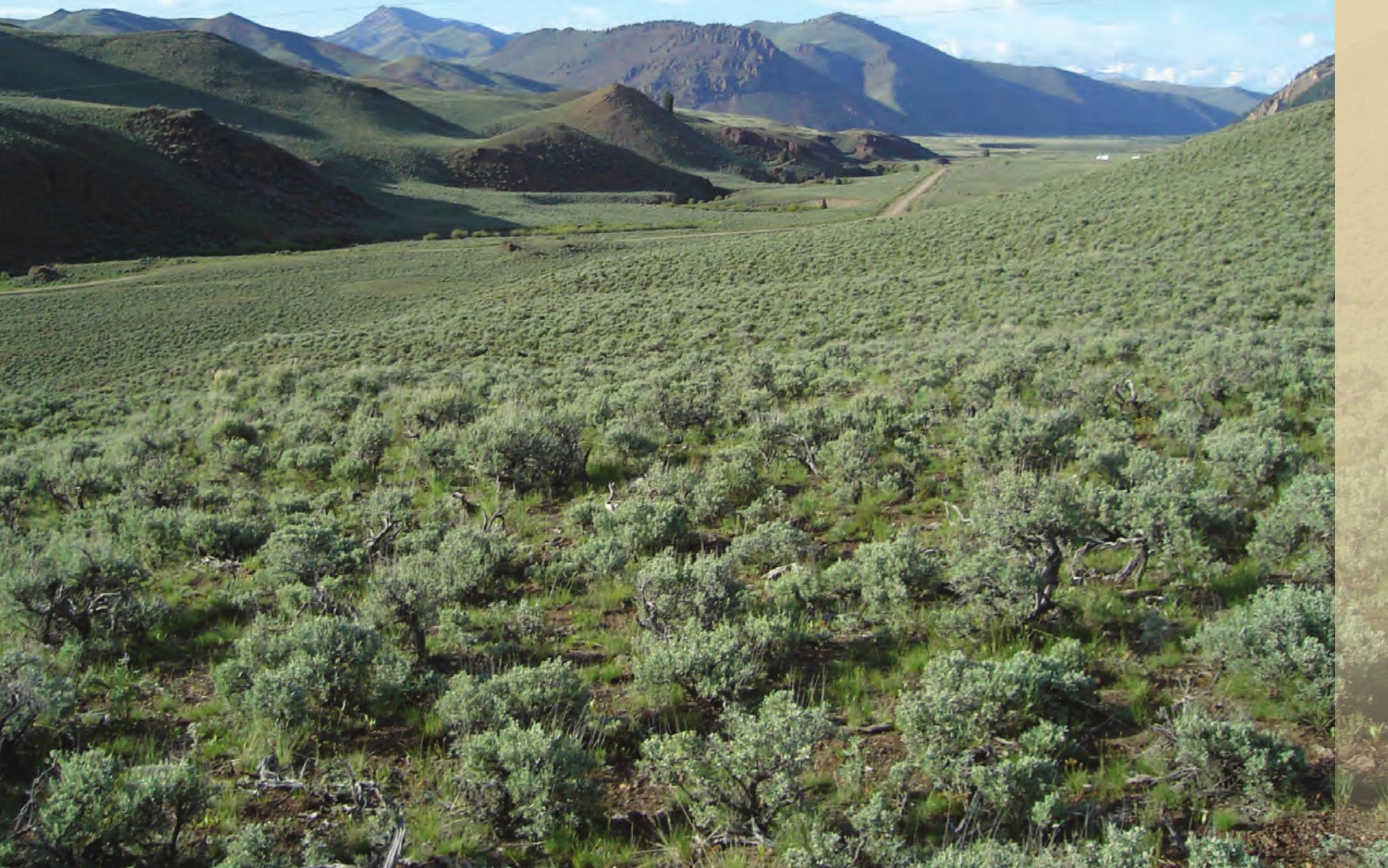




\section{Annotated Bibliography of Scientific Research on Greater Sage-Grouse}

The greater sage-grouse has been a focus of scientific investigation and management action for the past two decades. The sheer number of scientific publications can be a challenge for managers tasked with evaluating and determining the need for potential updates to existing planning documents. To assist in this process, USGS scientists have reviewed and summarized the scientific literature published from January 1, 2015, through January 6, 2018. USGS scientists conducted a structured search of reference databases for research or scientific review articles in peer-reviewed journals or formal government technical reports, and retaining only those products for which sage-grouse or their habitat was a research focus. Each product was summarized and assessed for relevance to a list of 31 management topics that included sage-grouse biology and habitat characteristics along with potential management actions, land uses, and environmental factors related to sage-grouse management and conservation. The online version of this bibliography is searchable by topic and location and includes links to all original publications.

\section{Contact}

Zachary H. Bowen, USGS Fort Collins Science Center; bowenz@usgs.gov; 970-226-9218

\section{Publication}

Carter, S.K., Manier, D.J., Arkle, R.S., Johnston, A.N., Phillips, S.L., Hanser, S.E., and Bowen, Z.H., 2018, Annotated bibliography of scientific research on greater sage-grouse published since January 2015: U.S. Geological Survey Open-File Report 2018-1008, 183 p., https://doi.org/10.3133/ofr20181008. [Interactive, searchable version is available at https://apps.usgs.gov/ gsgbib/index.php.]

\section{Greater Sage-Grouse Science (2015-17): Synthesis and Potential Management Implications}

The USGS led an interagency team of Federal and State agency biologists to develop a report that synthesizes the scientific literature published since records of decision were completed for the 2015 BLM and USDA Forest Service land use plan amendments for greater sage-grouse and provides potential management implications of the science. The interagency team identified six primary topic areas for the report: (1) multiscale habitat suitability and mapping tools, (2) discrete anthropogenic activities, (3) diffuse activities, (4) fire and invasive species, (5) restoration effectiveness, and (6) population estimation and genetics. The team then reviewed all material in the "Annotated Bibliography of Scientific Research on Sage-Grouse Published Since January 2015" (Carter and others, 2018) to identify the science that addressed each topic, discussed the science related to each topic, evaluated the consistency of the science with existing knowledge prior to 2015, and summarized the potential management implications of this science.

\section{Contact}

Steven E. Hanser, USGS Ecosystems Mission Area; shanser@usgs.gov; 703-648-4054

\section{Publication}

Hanser, S.E., Deibert, P.A., Tull, J.C., Carr, N.B., Aldridge, C.L., Bargsten, T.C., Christiansen, T.J., Coates, P.S., Crist, M.R., Doherty, K.E., Ellsworth, E.A., Foster, L.J., Herren, V.A., Miller, K.H., Moser, A., Naeve, R.M., Prentice, K.L., Remington, T.E., Ricca, M.A., Shinneman, D.J., Truex, R.L., Wiechman, L.A., Wilson, D.C., and Bowen, Z.H., 2018, Greater sage-grouse science (2015-17) — Synthesis and potential management implications: U.S. Geological Survey Open-File Report 2018-1017, 46 p., https://doi.org/10.3133/ofr20181017.

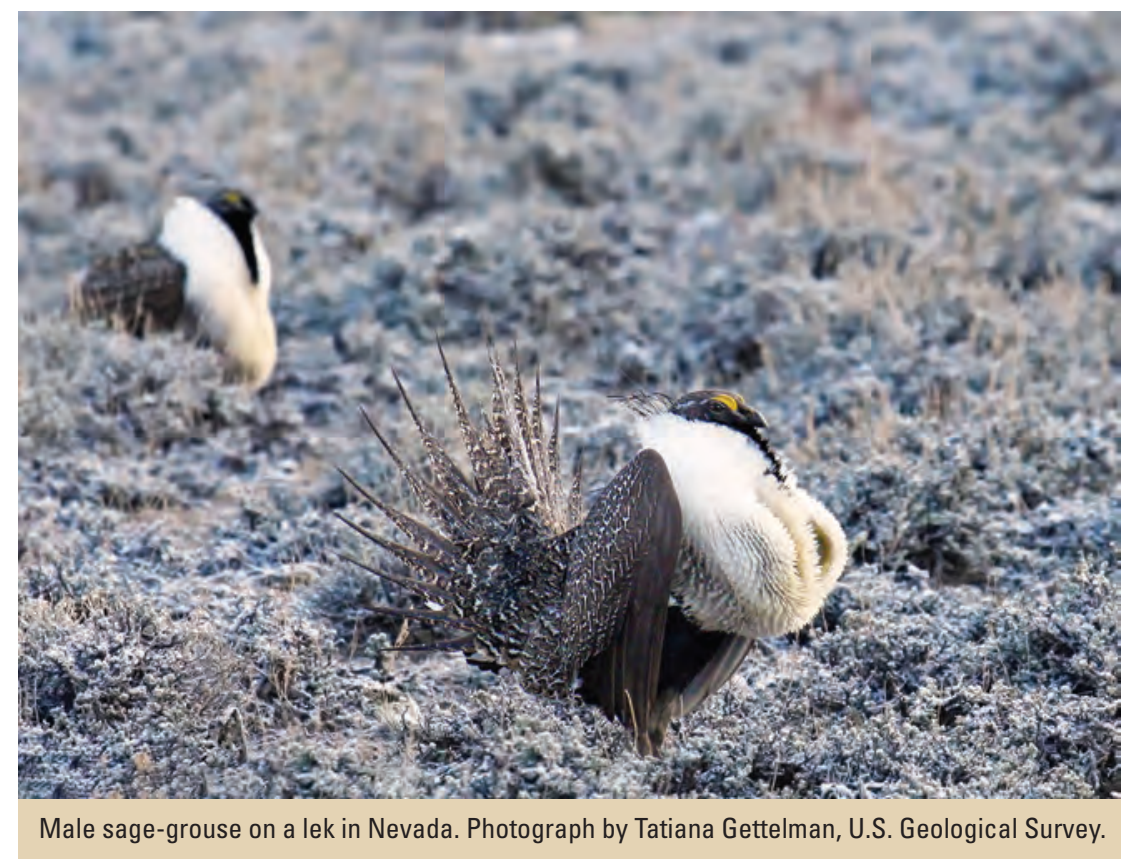




\section{Hierarchical Sage-Grouse Population Assessment Tool: Building a Foundation for True Adaptive Management}

Incorporating spatial and temporal scales into monitoring strategies can provide more robust detection of population rates of change and indication of whether trajectories for those rates of change are driven by local or regional factors. USGS scientists and colleagues have designed a hierarchical monitoring framework for greater sage-grouse in Nevada, Wyoming, and northeastern California that will assist Federal, State, and private land managers by providing a monitoring and detection system to identify sage-grouse breeding locations (known as leks), clusters of leks, and populations where intervention may be necessary to sustain populations and to evaluate effectiveness of conservation efforts. The team is working with the State wildlife agencies and the BLM to expand these approaches to the geographic range of sage-grouse and will develop methods to assess population change relative to vegetation characteristics, climate, disturbances such as fire and cheatgrass invasion, and other managementrelevant gradients.

\section{Contacts}

Peter S. Coates, USGS Western Ecological Research Center; pcoates@usgs.gov; 530-669-5073

Cameron L. Aldridge, Colorado State University, in cooperation with USGS Fort Collins Science Center; aldridgec@usgs.gov; 970-226-9433

\section{Publication}

Coates, P.S., Prochazka, B.G., Ricca, M.A., Wann, G.T., Aldridge, C.L., Hanser, S.E., Doherty, K.E., O’Donnell, M.S., Edmunds, D.R., and, Espinosa, S.P., 2017, Hierarchical population monitoring of greater sage-grouse (Centrocercus urophasianus) in Nevada and California-Identifying populations for management at the appropriate spatial scale: U.S. Geological Survey Open-File Report 2017-1089, 49 p., https://doi.org/10.3133/ofr20171089.

\section{Multiscale Statewide Wyoming Greater Sage-Grouse Trends Determined by Population Viability Analysis}

In Wyoming, USGS and CSU scientists are using population viability analysis to determine the rate of population change statewide and at multiple spatial scales within nested clusters of leks and across existing management units. This approach can identify clusters that are out of sync with surrounding populations and help identify the influence of local trends on larger scale population trajectories. This can provide new insight into management decisions that may help conserve populations across broad landscapes.

\section{Contacts}

Cameron L. Aldridge, Colorado State University, in cooperation with USGS Fort Collins Science Center; aldridgec@usgs.gov; 970-226-9433

David R. Edmunds, Colorado State University, in cooperation with USGS Fort Collins Science Center; dedmunds@usgs.gov; 970-226-9180

\section{Publication}

Edmunds, D.R., Aldridge, C.L., O'Donnell, M.S., and Monroe, A.P, 2018, Greater sage-grouse population trends across Wyoming: The Journal of Wildlife Management, v. 82, no. 2, p. $397-412$, https://doi.org/10.1002/ jwmg.21386.

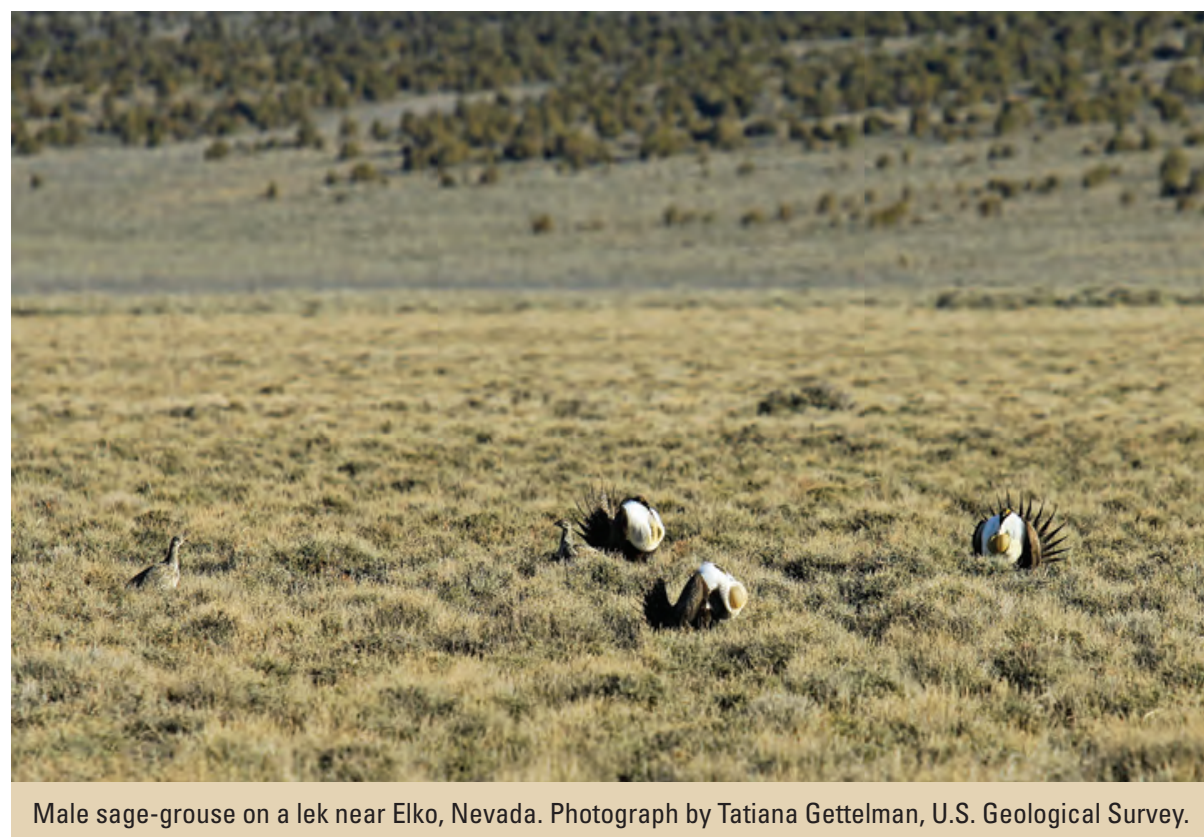




\section{Using Advanced Technologies To Improve Population Estimation From Lek Counts}

Population ecologists are challenged with estimating population growth of sensitive species on the basis of animal surveys that are often imperfect in detection. USGS scientists, in collaboration with State and university partners, are conducting multiple studies with advanced technologies to improve population estimates and growth rates from sage-grouse lek count observations. For example, scientists are using high-definition infrared cameras mounted on fixed wing aircraft simultaneously with double-blind ground observations to estimate detection probabilities. Moreover, scientists are employing advanced Global Positioning System (GPS) transmitters to collect fine-resolution movement data on male sage-grouse to calculate lek visitation rates. These findings will be used to calculate adjustment factors for lek surveys to account for sage-grouse not attending leks and those that were undetected. Adjusted counts could be used by State and Federal partners to improve accuracy of estimated population trends.

\section{Contact}

Peter S. Coates, USGS Western Ecological Research Center; pcoates@usgs.gov; 530-669-5073

\section{Publication}

Gillette, G.L., Coates, P.S., Petersen, S., and Romero, J.P., 2013, Can reliable sage-grouse lek counts be obtained using aerial infrared technology?: Journal of Fish and Wildlife Management, v. 4, no. 2, p. 386-394, https://doi.org/10.3996/032013-JFWM-025.

\section{The Importance of Simulation Assumptions When Evaluating Detection Bias in Lek Trend Models}

Greater sage-grouse lek counts are important for investigating a variety of questions, and population models can estimate detectability from repeated counts when modeling population size and trends. Past simulations used to evaluate these models typically assumed detectability is constant or random across sites and years. Thus, it is unknown how these models perform under scenarios when detectability is not constant or random. To address this uncertainty, USGS and CSU scientists are using GPS data from sage-grouse to inform simulations of the detection process for counts of this species, including scenarios where detection either varied randomly or declined linearly across years. This information will provide State and Federal biologists with more accurate estimates of sage-grouse populations and can lead to improved sage-grouse monitoring and population analysis protocols.

\section{Contacts}

Cameron L. Aldridge, Colorado State University, in cooperation with USGS Fort Collins Science Center; aldridgec@usgs.gov; 970-226-9433

Adrian P. Monroe, Colorado State University, in cooperation with USGS Fort Collins Science Center; amonroe@usgs.gov; 970-226-9122

\section{Evaluating Trends in Greater Sage-Grouse Populations With Quantile Regression}

USGS scientists are evaluating the use of a statistical technique known as quantile regression to develop models of sagegrouse population change. Estimates obtained from quantile regression are less sensitive to a few extreme population counts; can be estimated with an easier, more statistically justified approach to dealing with a few counts of zero; and can be extended to include additional covariates. Furthermore, this technique can provide a robust measure of trends and has fewer statistical assumptions. These features are likely to be especially beneficial in estimating population trends for greater sage-grouse.

\section{Contact}

Brian S. Cade, USGS Fort Collins Science Center; cadeb@usgs.gov; 970-226-9326 


\section{A Hierarchical Integrated Population Model for Greater Sage-Grouse in the Bi-State Distinct Population Segment in California and Nevada}

Genetic research has indicated isolation and potential conservation risk for the greater sagegrouse in the Bi-State Distinct Population Segment. The USGS developed an integrated population model (IPM) for this area to estimate population growth rates. The model indicates that the Bi-State population is stable overall, but evidence suggests a declining trend for one subpopulation. Scientists recently expanded the IPM to identify relationships between population growth rate and precipitation patterns. These findings provide a framework for hierarchical modeling strategies that separate climate-driven changes in populations from localscale disturbances. Researchers are now assessing which components of sage-grouse life history are driving population change as well as how and when climate influences particular life-history stages. This research informs active management planning processes in the Bi-State and this approach could be adapted to assess population trends for greater sagegrouse at other regional and landscape scales.

\section{Contact}

Peter S. Coates, USGS Western Ecological Research Center; pcoates@usgs.gov; 530-669-5073

\section{Publications}

Coates, P.S., Halstead, B.J., Blomberg, E J., Brussee, B., Howe, K.B., Wiechman, L., Tebbenkamp, J., Reese, K.P., Gardner, S.C., and Casazza, M.L., 2014, A hierarchical integrated population model for greater sage-grouse (Centrocercus urophasia$n u s)$ in the Bi-State Distinct Population Segment, California and Nevada: U.S. Geological Survey Open-File Report 2014-1165, 34 p., https://doi. org/10.3133/ofr20141165.

Coates, P.S., Prochazka, B.G., Ricca, M.A., Halstead, B.J., Casazza, M.L., Blomberg, E.J., Brussee, B.E., Wiechman, L., Tebbenkamp, J., Gardner, S.C., and Reese, K.P., 2018, The relative importance of intrinsic and extrinsic drivers to population growth vary among local populations of greater sage-grouse - An integrated population modeling approach: The Auk, Ornithological Advances, v. 135, no. 2, p. 240-261, https://doi. org/10.1642/AUK-17-137.1.

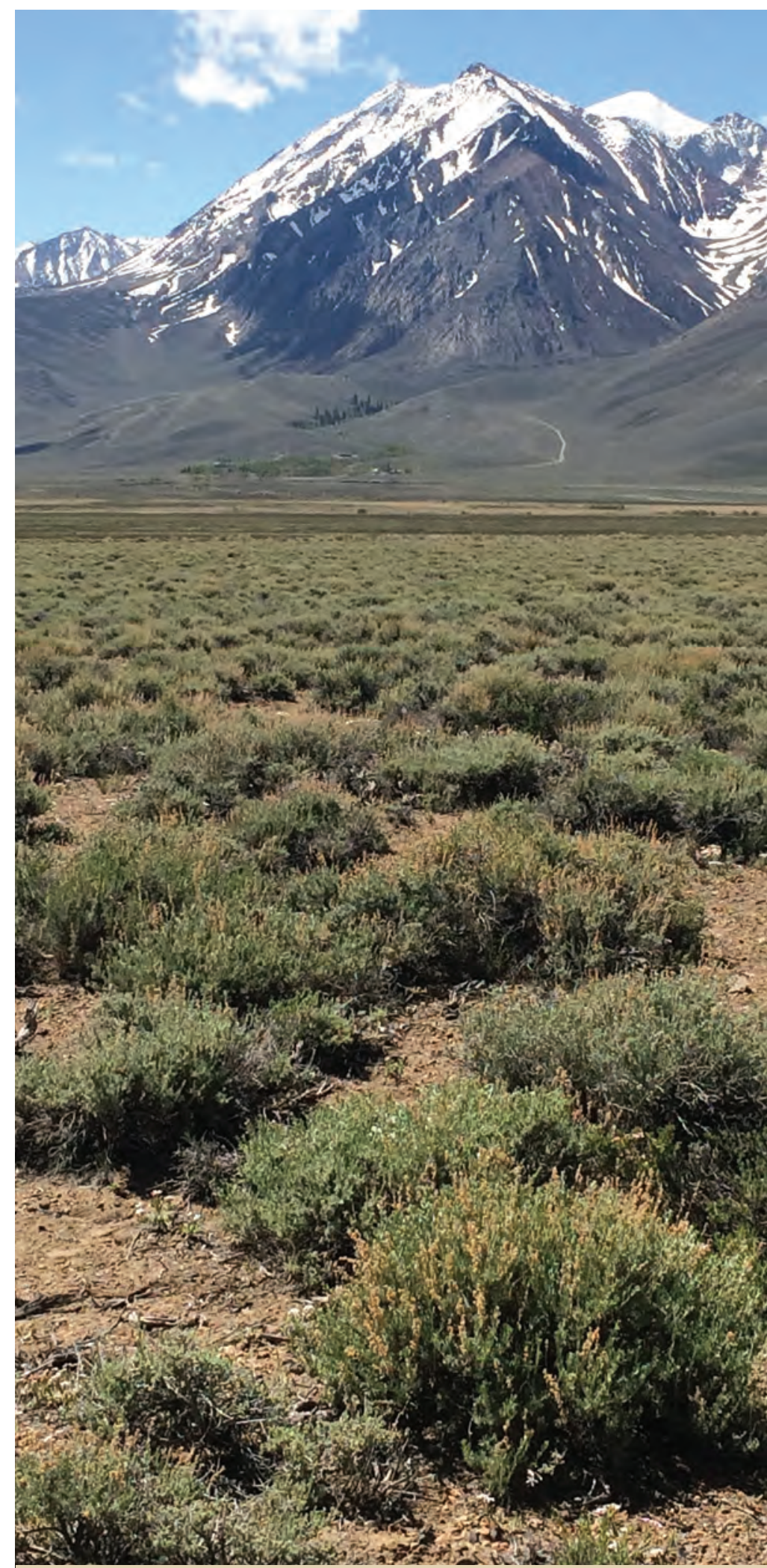

Habitat for sage-grouse in the Bi-State Distinct Population Segment on the CaliforniaNevada border. Photograph from U.S. Geological Survey. 


\section{Spatially Explicit Conservation Planning Tool for the Bi-State Distinct Population Segment of Greater Sage-Grouse}

Conservation planning efforts must account for a wide array of factors to assist future development, conserve native species, and improve habitat conditions. The USGS has developed a spatially explicit conservation planning tool within the Bi-State Distinct Population Segment that uses modeling results from sage-grouse habitat suitability and space use to assess and prioritize management actions. Examples include decision support for prioritizing restoration projects related to wildfire and pinyon and juniper treatments. Results demonstrate how the model output can be an important step in identifying management projects that yield the highest quantifiable benefit to sage-grouse while avoiding costly misallocation of resources. This information helps highlight the importance of considering both changes in sage-grouse responses and factors influencing sagebrush ecosystem resilience to disturbance and resistance to invasion. This novel framework can be adapted to answer other management questions aimed at improving habitat for species of conservation concern across sagebrush and other ecosystems.

\section{Contact}

Peter S. Coates, USGS Western Ecological Research Center; pcoates@usgs.gov; 530-669-5073

\section{Publications}

Duvall, A.L., Metcalf, A.L., and Coates, P.S., 2017, Conserving the greater sage-grouse-A social-ecological systems case study from the California-Nevada Region: Rangeland Ecology \& Management, v. 70, no. 1, p. 129-140, https://doi.org/10.1016/ j.rama.2016.08.001.

Ricca, M.A., Coates, P.S., Gustafson, K.B., Brussee, B.E., Chambers, J.C., Espinosa, S.P., Gardner, S.C., Lisius, S., Ziegler, P., Delehanty, D.J., and Casazza, M.L., 2018, A conservation planning tool for greater sage-grouse using indices of species distribution, resilience, and resistance: Ecological Applications, v. 28, no. 4, p. 878-896, https://doi.org/10.1002/eap.1690.

\section{Translocations as Conservation Strategy for Imperiled Populations of Sage-Grouse}

USGS scientists are working with Federal, State, and university collaborators to rescue severely declining populations of sage-grouse at the edge of the species' range. In 2017, translocation efforts began as part of a multiyear effort to infuse new individuals and genetic information into sage-grouse populations occupying the western extreme of the Bi-State Distinct Population Segment and the northeastern extent of the species range in western North Dakota. Using a variety of techniques that include very high frequency (VHF) and GPS technology, soft-release methods, artificial insemination, and release of pre-nesting hens as well as hens with broods, the researchers aim to ultimately develop a set of guidelines for effective sage-grouse translocations.

\section{Contact}

Peter S. Coates, USGS Western Ecological Research Center; pcoates@usgs.gov; 530-669-5073

\section{Greater Sage-Grouse Response to Habitat Restoration Efforts}

Sagebrush restoration efforts and greater sage-grouse translocations were initiated in 2005 to augment population numbers and prevent extirpation of the Devils Garden population in the FWS Klamath Basin National Wildlife Refuge Complex. Early monitoring efforts were conducted opportunistically without targeted objectives and with limited quantitative data collection. Scientists from the USGS Oregon Cooperative Fish and Wildlife Research Unit, in collaboration with those from Oregon State University and the FWS, are initiating a project to provide a robust evaluation of sage-grouse response to concurrent restoration activities to assess habitat conditions that could be limiting population growth and range expansion. This research will address knowledge gaps regarding dispersal and seasonal movements related to life-cycle needs of greater sage-grouse to inform future restoration actions and sage-grouse translocations.

\section{Contact}

Katie M. Dugger, USGS Oregon Cooperative Fish and Wildlife Research Unit; cdugger@usgs.gov; 541-737-2473 


\section{Spatially Explicit State-and-Transition Modeling for Rangeland Conservation Planning: Application to Outcome-Based Grazing and Sage-Grouse Habitat Monitoring}

The natural range of variability of the sagebrush ecosystem in the Great Basin is determined by local climate and topographic and soils relationships associated with plant community development. State-and-transition models (STMs) are widely used as a decision support tool for land managers and can be used to describe the ecological dynamics that occur within areas that respond similarly to natural or human-induced disturbances. These areas are referred to as Disturbance Response Groups (DRGs). Scientists from the USGS and University of Nevada-Reno are developing a conservation planning tool for sagegrouse across DRGs and testing the results of outcome-based grazing actions. This work will build on technological advances in remote sensing and land cover products to develop spatially explicit STM maps. Development of ecologically relevant maps will provide powerful tools for conservation planning for a variety of management actions including fuels treatments, grazing permit renewal, sage-grouse habitat management, and postfire rehabilitation.

\section{Contacts}

Peter S. Coates, USGS Western Ecological Research Center; pcoates@usgs.gov; 530-669-5073

Collin G. Homer, USGS Earth Resources Observation and Science Center; homer@usgs.gov; 605-594-2714

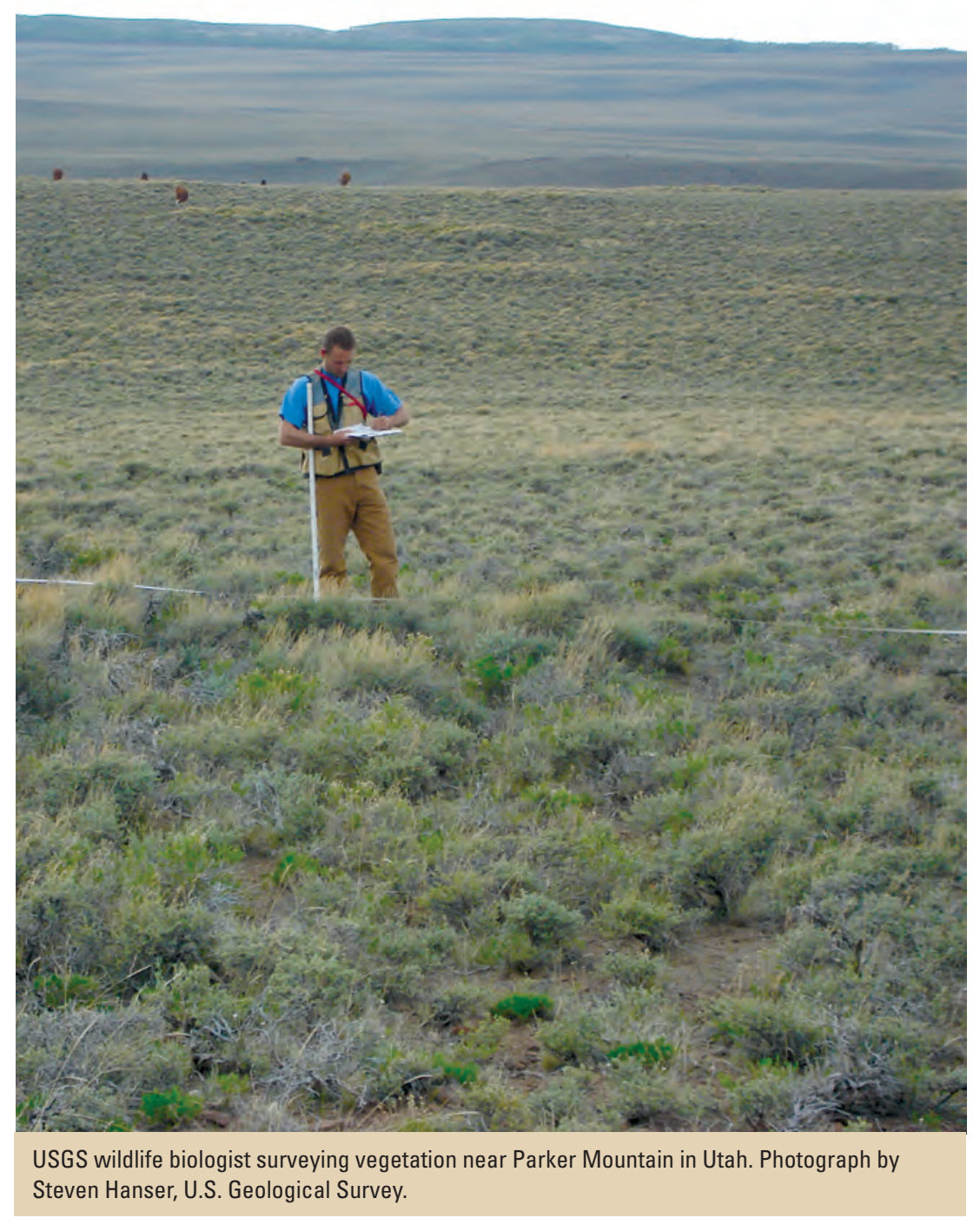

\section{Learning From the Land: Extending State-and-Transition Models for Adaptive Management of Wildlife Habitat on Western Rangelands}

USGS and CSU scientists have been working with other Federal and university partners to streamline and test STMs that incorporate sage-grouse habitat conditions. The researchers have demonstrated the utility of STMs for adaptive management of sage-grouse habitat and livestock production by developing models that predict the distribution and abundance of sage-grouse and sagebrush-associated songbirds in northwestern Colorado and by evaluating the effectiveness of sage-grouse as an umbrella species. This effort will increase awareness and may increase the adoption of STMs by ranchers while contributing to NRCS objectives of revising ecological site descriptions and promoting adaptive management and monitoring of sage-grouse habitat for Federal and State agencies.

\section{Contact}

Cameron L. Aldridge, Colorado State University, in cooperation with USGS Fort Collins Science Center; aldridgec@usgs.gov; 970-226-9433 


\section{Prioritizing Habitats for Dynamic Populations Using a Spatially Explicit Population Approach for Greater Sage-Grouse in Wyoming}

Although the use of resource selection models to identify and prioritize habitat for conservation is increasingly common, their success with characterizing important long-term habitats for fluctuating populations and seasonally dynamic habitat needs is variable. To examine how habitats might be prioritized differently if resource selection was directly and dynamically linked with population fluctuations and movement limitations among seasonal habitats, USGS and university scientists constructed a spatially explicit individual-based model for greater sage-grouse across Wyoming. This approach integrates seasonal habitat selection with designated management core areas, demographic and lek data, movement behavior, and West Nile virus outbreaks. Spatial simulation modeling may provide an informative means of predicting long-term habitat use for sage-grouse, indicating habitats that are likely to be valuable for sage-grouse persistence in the future, thus providing land managers with habitat conservation targets. Such approaches can provide land managers with the tools to create nuanced and longer term habitat prioritizations to support sage-grouse populations across broad space, time, and population fluctuations.

\section{Contacts}

Cameron L. Aldridge, Colorado State University, in cooperation with USGS Fort Collins Science Center; aldridgec@usgs.gov; 970-226-9433

Julie A. Heinrichs, Colorado State University, in cooperation with USGS Fort Collins Science Center; jheinrichs@usgs.gov; 970-226-9149

\section{Publication}

Heinrichs, J.A., Aldridge, C.L., O’Donnell, M.S., and Schumaker, N.H., 2017, Using dynamic population simulations to extend resource selection analyses and prioritize habitats for conservation: Ecological Modelling, v. 359, p. 449-459, https://doi.org/10.1016/j.ecolmodel.2017.05.017.

\section{Greater Sage-Grouse Seasonal Habitat Models}

Sage-grouse have a variety of habitat needs, and understanding these requirements in a spatial context is important to inform management strategies. USGS and CSU scientists developed seasonal habitat suitability models for the Great Basin by incorporating region-specific habitat conditions specified in the 2015 BLM resource management plans, the USGS shrub-map products, and other resource-condition data. The researchers are producing maps for breeding, nesting, brood-rearing, and summer habitat. This first iteration of model development will be useful for identifying opportunities and limitations when using site-level habitat characteristics to develop landscape-level map products.

\section{Contacts}

Cameron L. Aldridge, Colorado State University, in cooperation with USGS Fort Collins Science Center; aldridgec@usgs.gov; 970-226-9433

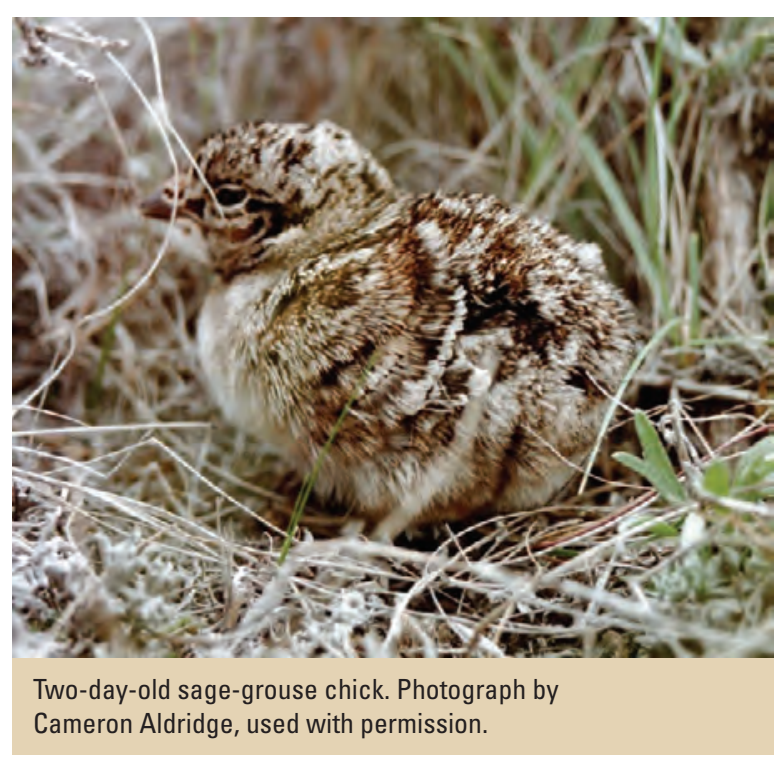

Michael O'Donnell, USGS Fort Collins Science Center; odonnellm@usgs.gov; 970-226-9407 


\section{Greater Sage-Grouse Population Ecology}

USGS scientists and colleagues are developing a peer-reviewed book on comprehensive population ecology of greater sage-grouse including analyses of habitat associations in relation to demographic rates. The book will consist of different sections, each focusing on a specific life stage (for example, nesting, broodrearing, wintering, and so forth) with individual chapters focused on estimated vital rates and specific macrohabitat and microhabitat needs across different ecoregions of the sage-grouse range. Book chapters will be written by subject experts from their respective ecoregions and will be quantitative in nature. This will provide a "desktop synthesis" for land and wildlife managers and policymakers to access and reference scientific information for land and wildlife management and policy decisions and will form the basis for ecoregion-specific and compre-

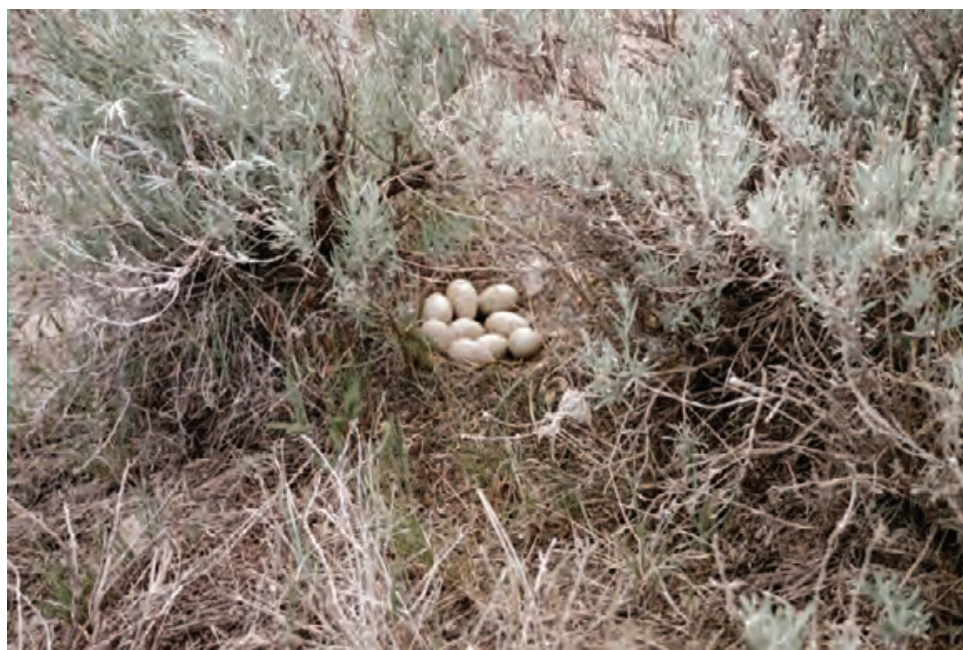

Sage-grouse nest. Photograph by Cameron Aldridge, used with permission. hensive management guidelines.

\section{Contact}

Peter S. Coates, USGS Western Ecological Research Center; pcoates@usgs.gov; 530-669-5073

\section{Microhabitat Requirements of Greater Sage-Grouse Within the Great Basin}

Habitat management guidelines with specific management objectives for greater sage-grouse habitat requirements have been published. A disproportionate number of the scientific studies on which these guidelines are based have focused on the northeastern portion of sage-grouse range and might not accurately reflect the Great Basin ecosystem. Building on information in the population ecology book described above, the second synthesis will culminate in an easy-to-follow management guideline handbook specifically focused on the Great Basin. The study includes an evaluation of existing macrohabitat and microhabitat objectives across life-history stages and will use a multiyear dataset of VHF and GPS telemetry data and microhabitat measures collected across more than 12 sites in the Great Basin. This study will provide statistics regarding numerous microhabitat factors for selection and survival to meet timely and best-available science needs for land managers and policymakers.

\section{Contact}

Peter S. Coates, USGS Western Ecological Research Center; pcoates@usgs.gov; 530-669-5073

\section{Publication}

Coates, P.S., Brussee, B.E., Ricca, M.A., Dudko, J.E., Prochazka, B.G., Espinosa, S.P., Casazza, M.L., and Delehanty, D.J., 2017, Greater sage-grouse (Centrocercus urophasianus) nesting and brood-rearing microhabitat in Nevada and California-Spatial variation in selection and survival patterns: U.S. Geological Survey Open-File Report 2017-1087, 79 p., https://doi.org/10.3133/ofr20171087. 


\section{SageDAT: Data and Tools To Support Collaborative Sagebrush Ecosystem Conservation and Management}

The USGS, the BLM, the FWS, and the Western Association of Fish and Wildlife Agencies have recently initiated development of a new DOI-funded effort, known as SageDAT. SageDAT, which can be accessed at https://sagedat.org, provides a mechanism for sharing and leveraging of data resources, increasing communication and coordination between organizations, and allowing for broader participation and transparency in decision making. The SageDAT team is using emerging technologies to allow effective sharing and discoverability of relevant data and tools that can be used to address the complex challenges that exist in sagebrush ecosystems including wildfire, invasive annual grass species, land use management, and assessments focusing on the greater sage-grouse.

\section{Contacts}

Steven E. Hanser, USGS Ecosystems Mission Area; shanser@usgs.gov; 703-648-4054

Tim Kern, USGS Fort Collins Science Center; kernt@usgs.gov; 970-226-9366

\section{Remote Sensing Characterization and Monitoring of Shrubland Components in the Western United States}

The USGS, in collaboration with the BLM, is producing a remote sensing-based characterization of shrublands in the Western United States, with sagebrush lands being the priority. This work will provide a suite of datasets that not only characterize the landscape in ways to maximize application utility but also provide a foundation for both historical and future monitoring at ecosystem scales. In each 30-meter grid cell, these products quantify the proportion of shrub, sagebrush, herbaceous, annual herbaceous, litter, and bare ground at 1-percent intervals and the height of shrubs and sagebrush in centimeters. Research has shown this information enables generation of a variety of wildlife habitat predictions including sage-grouse habitat. Products will be integrated into the National Land Cover Database for future updating on a regular 5-year cycle, and current products are available at https://www.mrlc.gov/nlcdshrub.php.

\section{Contact}

Collin G. Homer, USGS

Earth Resources

Observation and

Science Center;

homer@usgs.gov;

605-594-2714

\section{Publication}

Xian, G., Homer, C., Meyer, D., and Granneman, B., 2013, An approach for characterizing the distribution of shrubland ecosystem components as continuous fields as part of NLCD: ISPRS Journal of Photogrammetry and Remote Sensing, v. 86 , p. 136-149, https://doi.org/ 10.1016/j.isprsjprs. 2013.09.009.

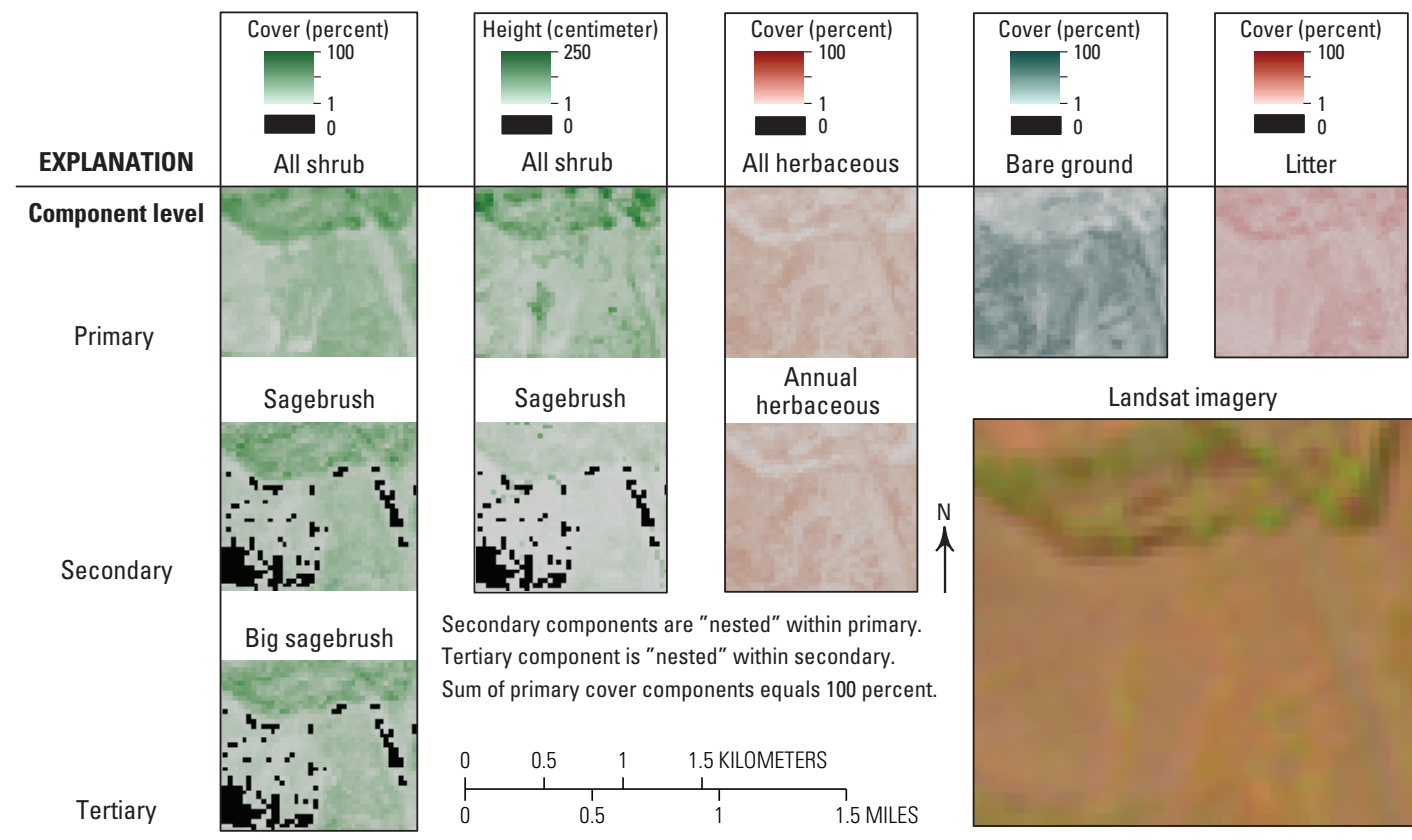

Mapped shrubland components, sorted by their hierarchical level. Component groups are contained by black boxes. For example, within the all shrub primary component group, sagebrush is secondary, and big sagebrush is tertiary. So big sagebrush cover and extent is never greater than sagebrush. Similarly, sagebrush cover and extent is never greater than all shrub cover. The sum of primary cover components (all shrub, all herbaceous, bare ground, and litter) is 100 percent in a typical rangeland environment. Pixels with zero percent cover or height for each component are depicted in black pixels (from Young, 2017). 


\section{Developing Temporal Trends in Sagebrush Vegetation Characteristics Over a Large Landscape}

The completion of the USGS shrubland component maps (see previous project) provides an opportunity to map vegetation component change back in time, from 1984 through 2016. Products that describe change over time support research in sagegrouse habitat and population dynamics, restoration success, future climate change forecasting and trend analysis, treatment recovery analysis, and cheatgrass change dynamics. This new approach automates component change analysis by Landsat path and row, and has been developed as an extensive scripted process to support processing huge amounts of data. This approach allows unprecedented comprehensive analysis of shrub and grass change across time. Data for the Great Basin and Wyoming are now being processed. Once the historical analysis is completed, future imagery can be easily added to monitor changing conditions into the future. New areas are planned to be completed as funding becomes available.

\section{Contact}

Collin G. Homer, USGS Earth Resources Observation and Science Center; homer@usgs.gov; 605-594-2714

\section{Publications}

Homer, C.G., Xian, G., Aldridge, C.L., Meyer, D.K., Loveland, T.R., and O’Donnell, M.S., 2015, Forecasting sagebrush ecosystem components and greater sage-grouse habitat for 2050 - Learning from past climate patterns and Landsat imagery to predict the future: Ecological Indicators, v. 55, p. 131-145, https://doi.org/10.1016/j.ecolind.2015.03.002.

Shi, H., Rigge, M., Homer, C.G., Xian, G., Meyer, D.K., and Bunde, B., 2017, Historical cover trends in a sagebrush steppe ecosystem from 1985 to 2013 - Links with climate, disturbance, and management: Ecosystems, v. 21, no. 5, p. 913-929, https://doi.org/10.1007/s10021-017-0191-3.

\section{Understanding Drivers of Change in Rangeland Vegetation}

Rangeland vegetation is influenced by annual and seasonal variation in weather as well as grazing, invasive species, fire, and other factors. Understanding whether and why vegetation communities are resistant to change and resilient following disturbance is an important area of ecology and crucial for conservation and restoration strategies. This project takes advantage of multiple, existing data sources to improve understanding of the drivers of change in rangeland vegetation communities across the Western United States, including data from historic field surveys in the late 1970s (BLM's Soil - Vegetation Inventory Method) to ongoing field (BLM's Assessment Inventory and Monitoring Program) and remote sensing (USGS's grass-shrub products) datasets.

\section{Contacts}

David S. Pilliod, USGS Forest and Rangeland Ecosystem Science Center; dpilliod@usgs.gov; 208-426-5202

Collin G. Homer, USGS Earth Resources Observation and Science Center; homer@usgs.gov; 605-594-2714

\section{Publication}

Barker, B.S., Pilliod, D.S., Welty, J.L., Arkle, R.S., Karl, M.G., and Toevs, G.R., 2018, An introduction and practical guide to use of the Soil-Vegetation Inventory Method (SVIM) data: Rangeland Ecology \& Management, Corrected Proof posted August 6, 2018, 10 p., https://doi.org/10.1016/j.rama.2018.06.003.

\section{Mapping Conifer Within California and Nevada}

Conifer encroachment is a threat to the extent of sagebrush shrublands in the Great Basin. High-resolution maps of conifers within sagebrush ecosystems are lacking. These maps would be highly useful to land and wildlife management agencies for habitat improvement plans. Therefore, the USGS is currently mapping conifer at 1-meter resolution across Nevada and northeastern California. This analysis uses specialized image recognition software to develop usable geographic information system (GIS) files of conifer coverage. In areas thought to be pinyon and juniper, the USGS is using criteria to delineate the conifer map into cover classifications at 30-meter resolution to approximate phases of conifer encroachment. These maps will help inform management and conservation strategies including tree removal to enhance sagebrush ecosystems and sage-grouse populations.

\section{Contact}

Peter S. Coates, USGS Western Ecological Research Center; pcoates@usgs.gov; 530-669-5073 


\section{Publications}

Coates, P.S., Gustafson, K.B., Roth, C.L., Chenaille, M.P., Ricca, M.A., Mauch, K., Sanchez-Chopitea, E., Kroger, T.J., Perry, W.M., and Casazza, M.L., 2017a, Geospatial data for object-based high-resolution classification of conifers within greater sage-grouse habitat across Nevada and a portion of northeastern California (ver. 2.0 July 2018): U.S. Geological Survey data release, https://doi.org/10.5066/F7348HVC.

Coates, P.S., Gustafson, K.B., Roth, C.L., Chenaille, M.P., Ricca, M.A., Mauch, K., Sanchez-Chopitea, E., Kroger, T.J., Perry, W.M., and Casazza, M.L., 2017b, Using object-based image analysis to conduct high-resolution conifer extraction at regional spatial scales: U.S. Geological Survey Open-File Report 2017-1093, 40 p., https://doi.org/10.3133/ofr20171093.

Gustafson, K.B., Coates, P.S., Roth, C.L., Chenaille, M.P., Ricca, M.A., Sanchez-Chopitea, E., and Casazza, M.L., 2018, Using object-based image analysis to conduct high-resolution conifer extraction at regional spatial scales: International Journal of Applied Earth Observation and Geoinformation, v. 73, p. 148-155, https://doi.org/10.1016/j.jag.2018.06.002.

Roth, C.L., Coates, P.S., Gustafson, K.B., Chenaille, M.P., Ricca, M.A., Sanchez-Chopitea, E., Casazza, M.L., in press, A customized framework for regional classification of conifers using automated feature extraction: MethodsX.

\section{Comparison of Techniques in Mapping Conifers}

Accurate mapping of pinyon and juniper trees is important for planning the location of treatments. Despite multiple techniques in mapping conifers and developing coverages for a GIS, limited research is available that addresses the advantages and disadvantages to the most common techniques. The USGS is comparing two of the most used mapping techniques - spatial wavelet analysis and image recognition feature analysis - to help improve existing mapping efforts and spatial data layers for use in the planning process. This comparison will help management and conservation agencies develop and update coverages of conifers for sage-grouse and sagebrush ecosystem conservation planning.

\section{Contact}

Peter S. Coates, USGS Western Ecological Research Center; pcoates@usgs.gov; 530-669-5073

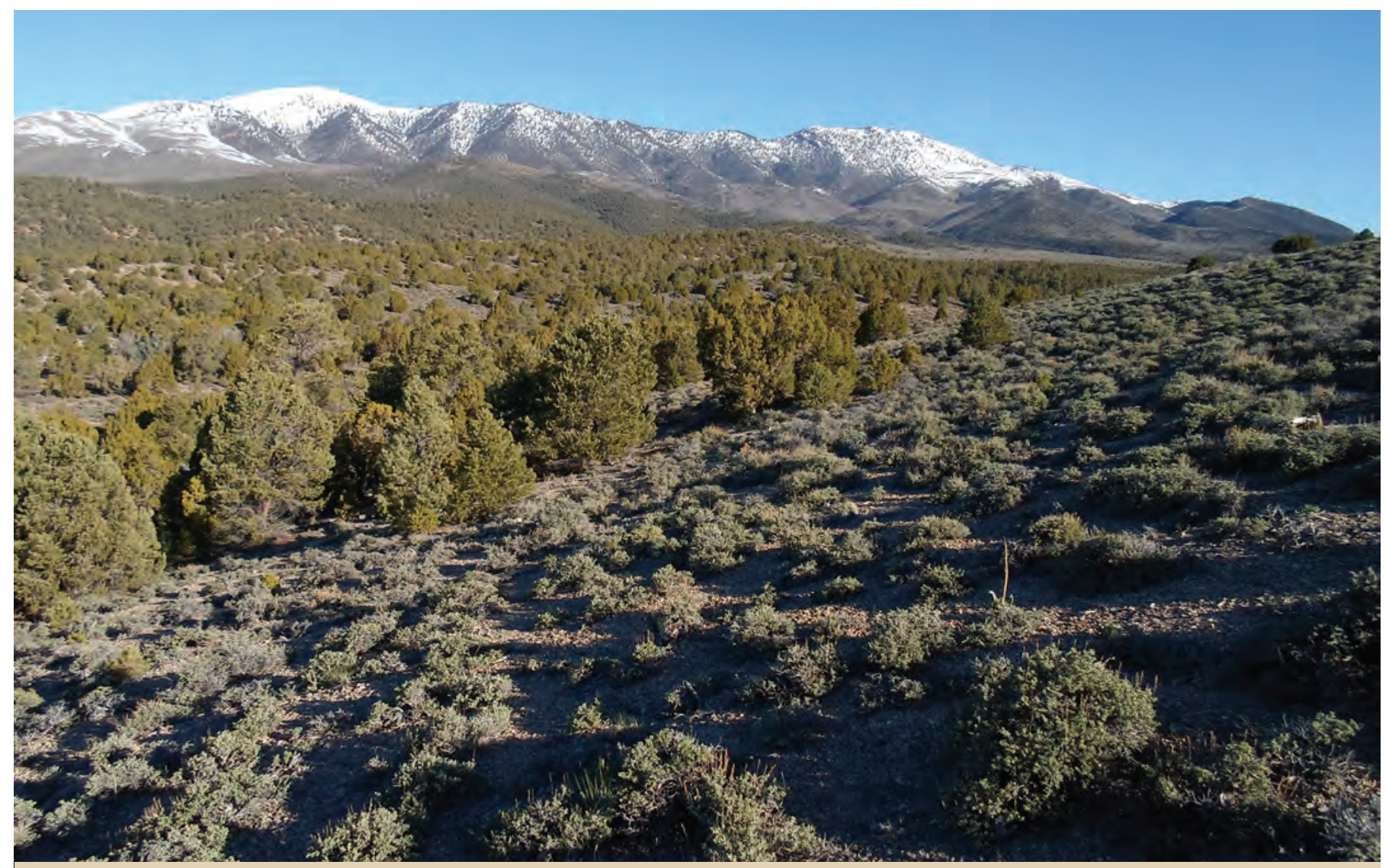

Conifer woodland and sagebrush on Spruce Mountain in Nevada. Photograph by Steven Hanser, U.S. Geological Survey. 


\section{Mapping of Greater Sage-Grouse Habitat in Nevada and Northeastern California}

The USGS is studying the cumulative impacts of expanding human activities across sagebrush landscapes in Nevada and northeastern California. By combining land cover information with data on sage-grouse movement patterns, life history and reproductive ecology, and habitat preferences, researchers can create maps that forecast the interaction of proposed land use activities and the sagebrush ecosystem. Maps help predict where fragmentation of sage-grouse movement corridors and breeding grounds might occur and assess the relationships between land use and native and invasive species. Additional work is now underway that will (1) describe spatial variation in habitat selection through meta-analyses, (2) identify life-history-specific macrohabitat requirements, and (3) depict spatially explicit survival consequences of habitat selection decisions by sage-grouse. This research can inform land managers' conservation planning efforts for sage-grouse and the habitats on which they rely.

\section{Contact}

Peter S. Coates, USGS Western Ecological Research Center; pcoates@usgs.gov; 530-669-5073

\section{Publications}

Coates, P.S., Casazza, M.L., Brussee B.E., Ricca, M.A., Gustafson, K.B., Sanchez-Chopitea, E., Mauch, K., Niell, L., Gardner, S., Espinosa, S., and Delehanty, D.J., 2016, Spatially explicit modeling of annual and seasonal habitat for greater sage-grouse (Centrocercus urophasianus) in Nevada and Northeastern California-An updated decision-support tool for management:

U.S. Geological Survey Open-File Report 2016-1080, 160 p., https://doi.org/10.3133/ofr20161080.

Coates, P.S., Casazza, M.L., Ricca, M.A., Brussee, B.E., Blomberg, E.J., Gustafson, K.B., Overton, C.T., Davis, D.M., Niell, L.E., Espinosa, S.P., Gardner, S.C., and Delehanty, D.J., 2016, Integrating spatially explicit indices of abundance and habitat quality - An applied example for greater sage-grouse management: Journal of Applied Ecology, v. 53, no. 1, p. 83-95, https://doi.org/10.1111/1365-2664.12558.

\section{Sagebrush Ecosystem Performance Mapping in the Great Basin}

Vegetation productivity can be highly variable in arid and semiarid systems. Moisture-related variations in plant productivity add variability to time series data that is not related to management or disturbance. To isolate management and disturbance effects in these systems, "performance" models are being developed that predict sagebrush annual productivity each year from 2000 to 2016. The deviations of the performance model account for both interannual variation in weather and spatial variation in site potential. Performance anomalies show where the vegetation is not responding to site and weather conditions as would be expected in a healthy sagebrush community. This information will identify areas that are overperforming or underperforming relative to the surrounding landscape and provide managers with a tool to refine or target actions to improve vegetation conditions.

\section{Contact}

Bruce K. Wylie, USGS Earth Resources Observation and Science Center; wylie@ usgs.gov; 605-594-6078

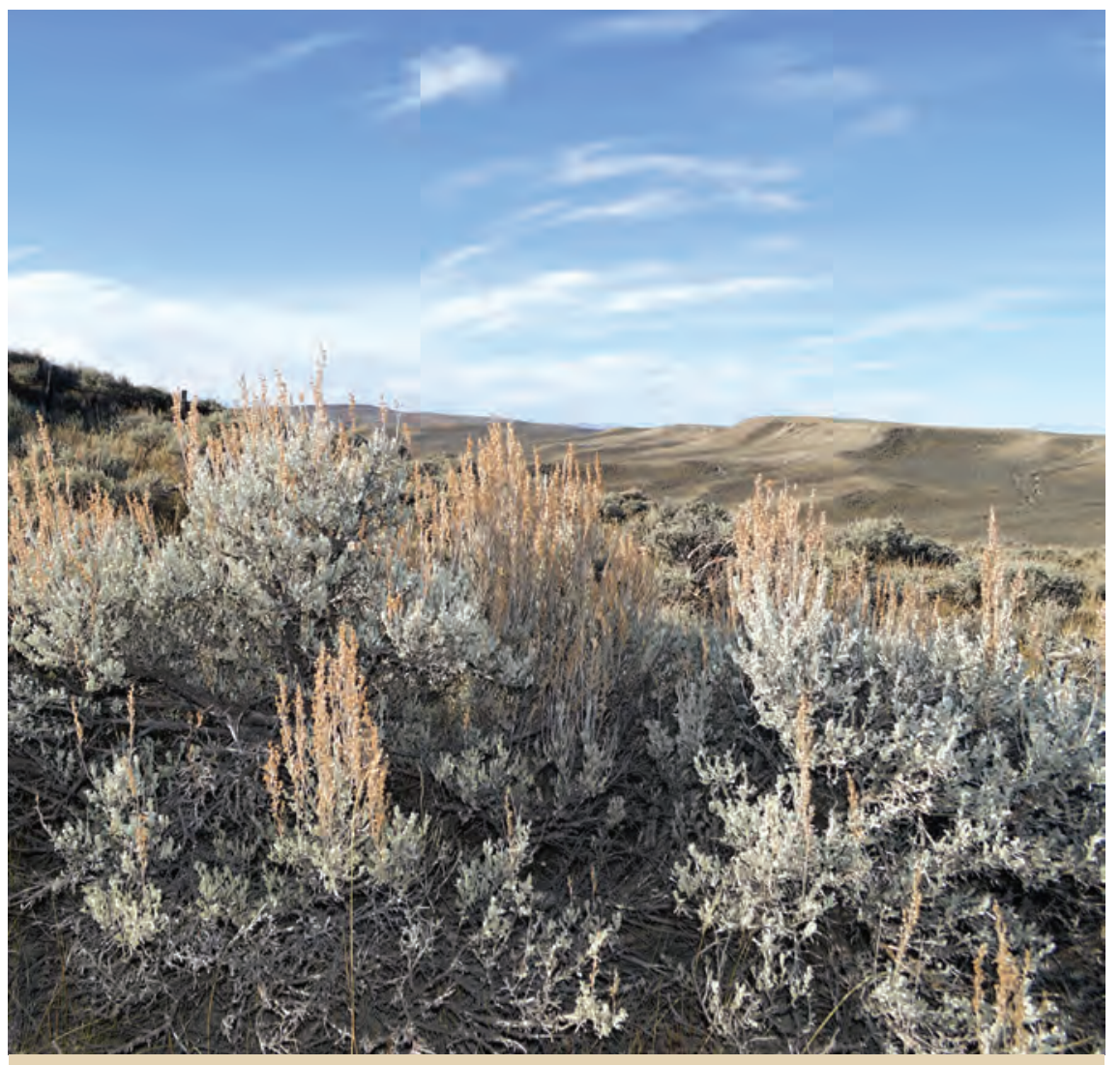

Healthy sagebrush in Wyoming. Photograph by Theo Stein, U.S. Fish and Wildlife Service. 


\section{Landscape Influence on Gene Flow in Greater Sage-Grouse}

The USGS and collaborators at the USDA Forest Service and University of Waterloo are using genetic information contained in sage-grouse feathers collected at leks to delineate the rangewide network of breeding populations. The genetic data are being analyzed in combination with landscape information to identify geographic distance, topographic features, anthropogenic land uses, and other factors that influence sage-grouse dispersal and genetic exchange. The results from this study, perhaps the largest terrestrial effort of its kind, will be important for informing conservation planning efforts to delineate core or priority populations and reduce population fragmentation, isolation, and risk of extirpation.

\section{Contact}

Sara J. Oyler-McCance, USGS Fort Collins Science Center; sara_oyler-mccance@usgs.gov; 970-226-9197

\section{Publications}

Cross, T.B., Schwartz, M.K., Naugle, D.E., Fedy, B.C., Row, J.R., and Oyler-McCance, S.J., 2018, The genetic network of greater sage-grouse-Range-wide identification of keystone hubs of connectivity: Ecology and Evolution, v. 8, no. 11, p. 5394-5412, https://doi.org/10.1002/ece3.4056.

Row, J.R., Doherty, K.E., Cross, T.B., Schwartz, M.K., Oyler-McCance, S.J., Naugle, D.E., Knick, S.T., and Fedy, B.C., 2018, Quantifying functional connectivity - The role of breeding habitat, abundance, and landscape

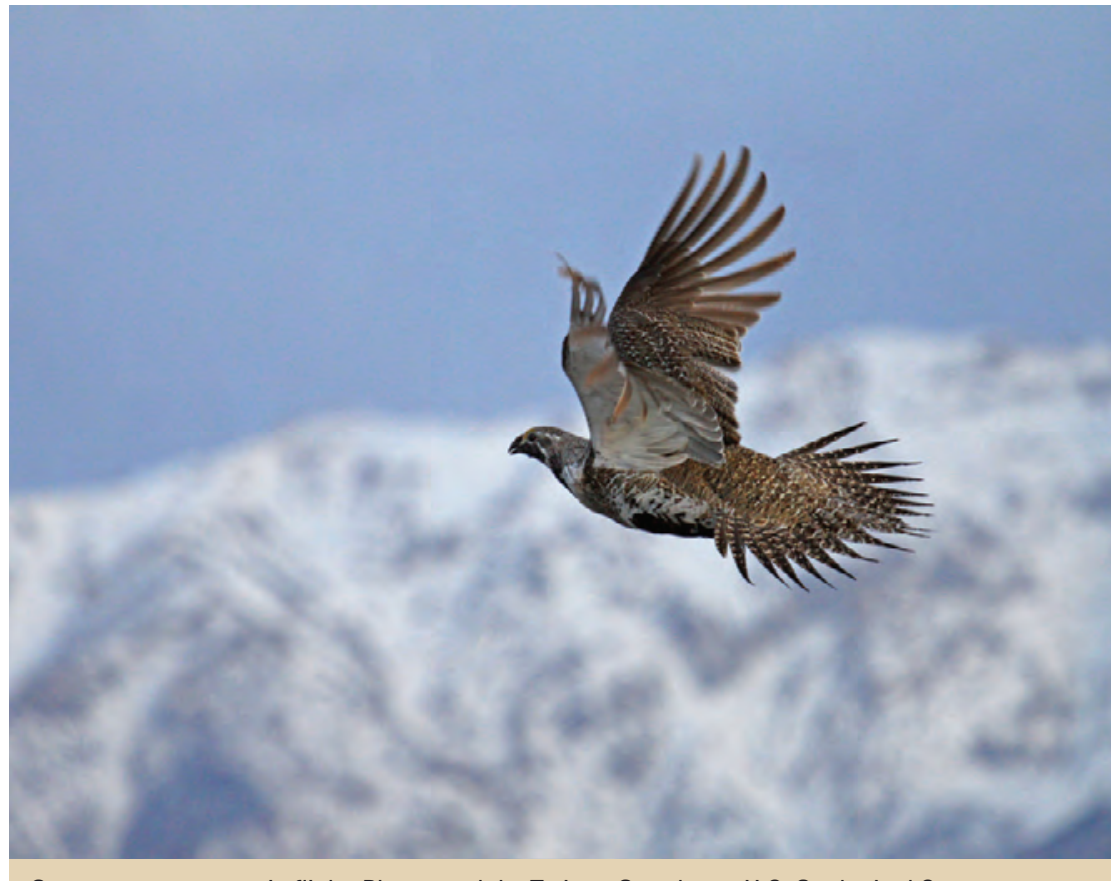
features on range-wide gene flow in sage-grouse: Evolutionary Applications, v. 11, no. 8, p. 1305-1321, https://doi.org/10.1111/eva.12627.

\section{Sage-Grouse Genomics}

USGS scientists and their collaborators have assembled a reference genome for both greater and Gunnison sage-grouse (Centrocercus minimus) and have performed whole-genome sequencing on six populations of greater sage-grouse (including several on the periphery of the species' range) and Gunnison sage-grouse. They found pronounced intraspecific population structure and highlighted differentiation of a small isolated population of greater sage-grouse in the northwest portion of the range. Patterns of genome-wide differentiation were largely consistent with limited gene flow among populations. Inferred ancient population demography suggested persistent declines in effective population sizes that have likely contributed to differentiation within and among species. Several genomic regions that did exhibit extreme population differentiation were associated with candidate genes linked to metabolism of xenobiotic compounds. In vitro activity of enzymes isolated from sage-grouse livers supported a role for these genes in detoxification of sagebrush, suggesting that the observed interpopulation variation may underlie important local dietary adaptations, warranting close consideration for conservation strategies that link sage-grouse to plant chemistry.

\section{Contact}

Sara J. Oyler-McCance, USGS Fort Collins Science Center; sara_oyler-mccance@usgs.gov; 970-226-9197 


\section{Genetic Implications of Translocations in Gunnison Sage-Grouse}

In an attempt to augment dwindling population sizes, Colorado Parks and Wildlife began translocating Gunnison sagegrouse from the largest population in the Gunnison Basin to small satellite populations. The effects of these translocations on the genetic composition of satellite populations are unknown. USGS scientists are investigating changes in genetic diversity, genetic differentiation, and whether translocated individuals are reproducing by characterizing genetic samples collected before and after translocations. This information can help inform future translocations into isolated populations.

\section{Contact}

Sara J. Oyler-McCance, USGS Fort Collins Science Center; sara_oyler-mccance@usgs.gov; 970-226-9197

\section{Landscape Genetic Assessment of Gunnison Sage-Grouse}

The range of the Gunnison sage-grouse has been fragmented into geographically and genetically distinct populations. The viability of the individual populations and long-term persistence of the species may be affected by the ability of individual birds to move between populations. USGS scientists and collaborators are using genetic samples to infer connectivity across the species range and between leks within the Gunnison Basin to gain insight on which landscape or habitat features are contributing to the fragmentation of the species range. The connectivity analysis within the basin will provide insight at a manageable scale and ultimately aims to inform current and future management scenarios by delineating corridors of movement and barriers to movement.

\section{Contact}

Sara J. Oyler-McCance, USGS Fort Collins Science Center; sara_oyler-mccance@usgs.gov; 970-226-9197

\section{Examining Adaptation in Gunnison Sage-Grouse}

The satellite populations of the Gunnison sage-grouse occupy various areas with a diversity of habitat and local environmental characteristics. With limited gene flow between populations and the potential for different selective pressures acting on each population, there is the potential for locally adapted variation. Local adaptation is important to long-term persistence of populations and pertinent to current management efforts. Pressures of changing precipitation, temperature, and land use differ among the populations, and any existing variation adapted to the unique pressures are best maintained for the long-term success of the population. USGS scientists are using genomic methods to look within each population for evidence of selection correlated with environmental variation. Identifying adaptive variation can contribute to more targeted management efforts and inform the maintenance of this variation within populations.

\section{Contact}

Sara J. Oyler-McCance, USGS Fort Collins Science Center; sara_oyler-mccance@usgs.gov; 970-226-9197

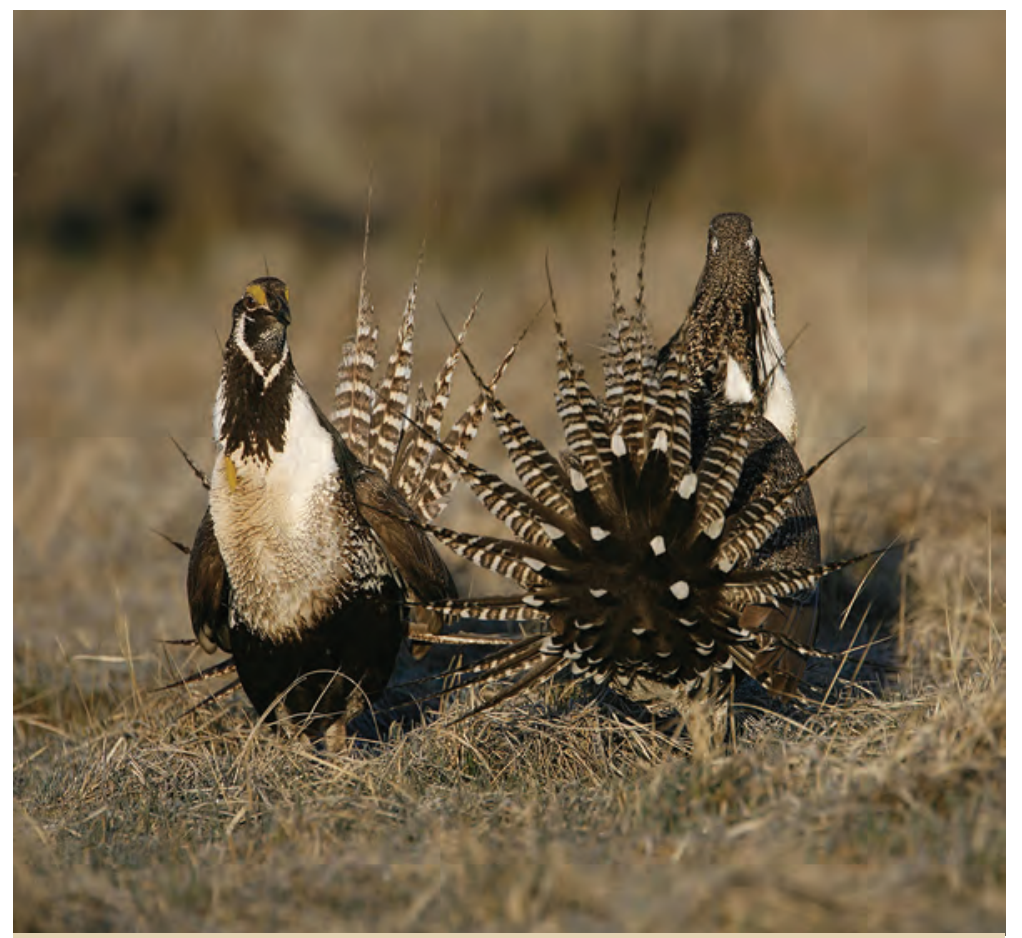

A pair of Gunnison sage-grouse. Photograph from U.S. Fish and Wildlife Service. 


\section{Identification of Crucial Late-Summer Brood-Rearing and Winter Habitat for Gunnison Sage-Grouse}

Gunnison sage-grouse is considered a threatened species under the Endangered Species Act, and knowledge of resource requirements across all life states can assist conservation planning efforts. USGS and CSU scientists and colleagues are using telemetry data to develop resource selection models predicting crucial brood-rearing and winter habitat for Gunnison sagegrouse within the Gunnison Basin. These models can help improve the conservation and management of important Gunnison sage-grouse habitat, thereby enhancing the management of disturbances and increasing habitat connectivity.

\section{Contact}

Cameron L. Aldridge, Colorado State University, in cooperation with USGS Fort Collins Science Center; aldridgec@usgs.gov; 970-226-9433

\section{Landscape Variability and Gunnison Sage-Grouse Conservation}

Loss and alteration of sagebrush habitat, owing to many factors, have been identified as a primary reason for declines in Gunnison sage-grouse populations. Within the Crawford population, one of seven remaining populations, USGS scientists are evaluating the impacts of habitat variability and developing spatially explicit models to better inform Gunnison sage-grouse conservation plans.

\section{Contact}

Douglas S. Ouren, USGS Fort Collins Science Center; ourend@usgs.gov; 970-226-9476

\section{Publication}

Ouren, D.S., Ignizio, D.A., Siders, M., Childers, T., Tucker, K., and Seward, N., 2014, Gunnison sage-grouse lek site suitability modeling: U.S. Geological Survey Open-File Report 2014-1010, 18 p., https://doi.org/10.3133/ofr20141010.

\section{Assessing Habitat, Risk, and Conservation Actions for Gunnison Sage-Grouse}

The threatened Gunnison sage-grouse continues to experience declines, particularly in satellite populations, and an understanding of habitat needs, risks to habitat, and the feasibility of conservation actions to improve habitat and population conditions are required for multiagency conservation planning. USGS and CSU scientists are supporting the FWS, along with Colorado Parks and Wildlife, as they develop habitat selection models for Gunnison sage-grouse throughout Colorado. Researchers are also supporting the BLM in evaluating the efficacy of habitat restoration and conservation actions for stabilizing and increasing Gunnison sage-grouse populations. This research includes characterizing habitat and population responses to past conservation actions and developing a spatially explicit individual-based model to simulate population responses to habitat change and evaluate the relative efficacy of alternative conservation actions.

\section{Contacts}

Julie A. Heinrichs, Colorado State University, in cooperation with USGS Fort Collins Science Center; jheinrichs@usgs.gov; 970-226-9149

Cameron L. Aldridge, Colorado State University, in cooperation with USGS Fort Collins Science Center; aldridgec@usgs.gov; 970-226-9433

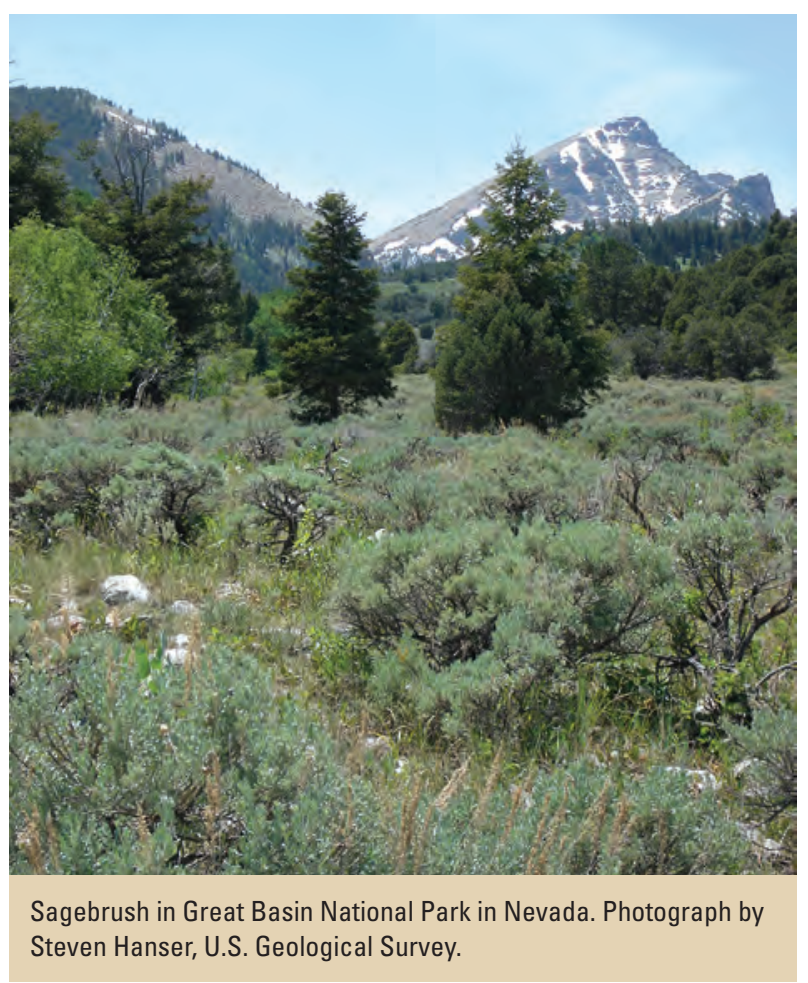




\section{Migration Corridors for Big Game}

As habitat loss and fragmentation increase across ungulate ranges, identifying and prioritizing migration routes for land use planning and conservation have taken on a new urgency. Currently, research attention is focused on determining whether continued energy development, without consideration for migration corridors, will lead to the loss of the foraging benefit of migration. Research from the USGS Wyoming Cooperative Fish and Wildlife Research Unit has increased understanding of the importance of migration for large ungulates in the Western United States, specifically quantifying how migrating animals track spring green-up during migration. In collaboration with Federal, State and university partners, the Wyoming Unit has developed the Migration Mapper software that provides a step-by-step analysis to map migration corridors, including low-, medium-, and high-use corridors, from GPS locations. Resulting corridor maps can be easily made available for managers, policymakers, land trusts, sportsmans' groups, and other nongovernmental organizations to use in conservation planning. A current effort is underway, through USGS-led regional workshops, to train wildlife managers from western States to analyze migration data, and the USGS continues to develop tools and methods necessary to identify opportunities to enhance conservation and management of ungulate migration corridors.

\section{Contact}

Matthew J. Kauffman, USGS Wyoming Cooperative Fish and Wildlife Research Unit; mkauffman@usgs.gov; 307-766-5415

\section{Publications}

Aikens, E.O., Kauffman, M.J., Merkle, J.A., Dwinnell, S.P.H., Fralick, G.L., and Monteith, K.L., 2017, The greenscape shapes surfing of resource waves in a large migratory herbivore: Ecology Letters, v. 20, no. 6, p. 741-750, https://doi.org/10.1111/ ele.12772.

Courtemanch, A.B., Kauffman, M.J., Kilpatrick, S., and Dewey, S.R., 2017, Alternative foraging strategies enable a mountain ungulate to persist after migration loss: Ecosphere, v. 8, no. 6, article e01855, 16 p., https://doi.org/10.1002/ecs2.1855.

Merkle, J.A., Monteith, K.L., Aikens, E.O., Hayes, M.M., Hersey, K.R., Middleton, A.D., Oates, B.A., Sawyer, H., Scurlock, B.M., and Kauffman, M.J., 2016, Large herbivores surf waves of green-up during spring: Proceedings of the Royal Society B, v. 283, no. 1833, 8 p., https://doi.org/10.1098/rspb.2016.0456.

Middleton, A.D., Merkle, J.A., McWhirter, D.E., Cook, J.G., Cook, R.C., White, P.J., and Kauffman, M.J., 2018, Green-wave surfing increases fat gain in a migratory ungulate: Oikos, v. 127, no. 7, p. 1060-1068, https://doi.org/10.1111/oik.05227.

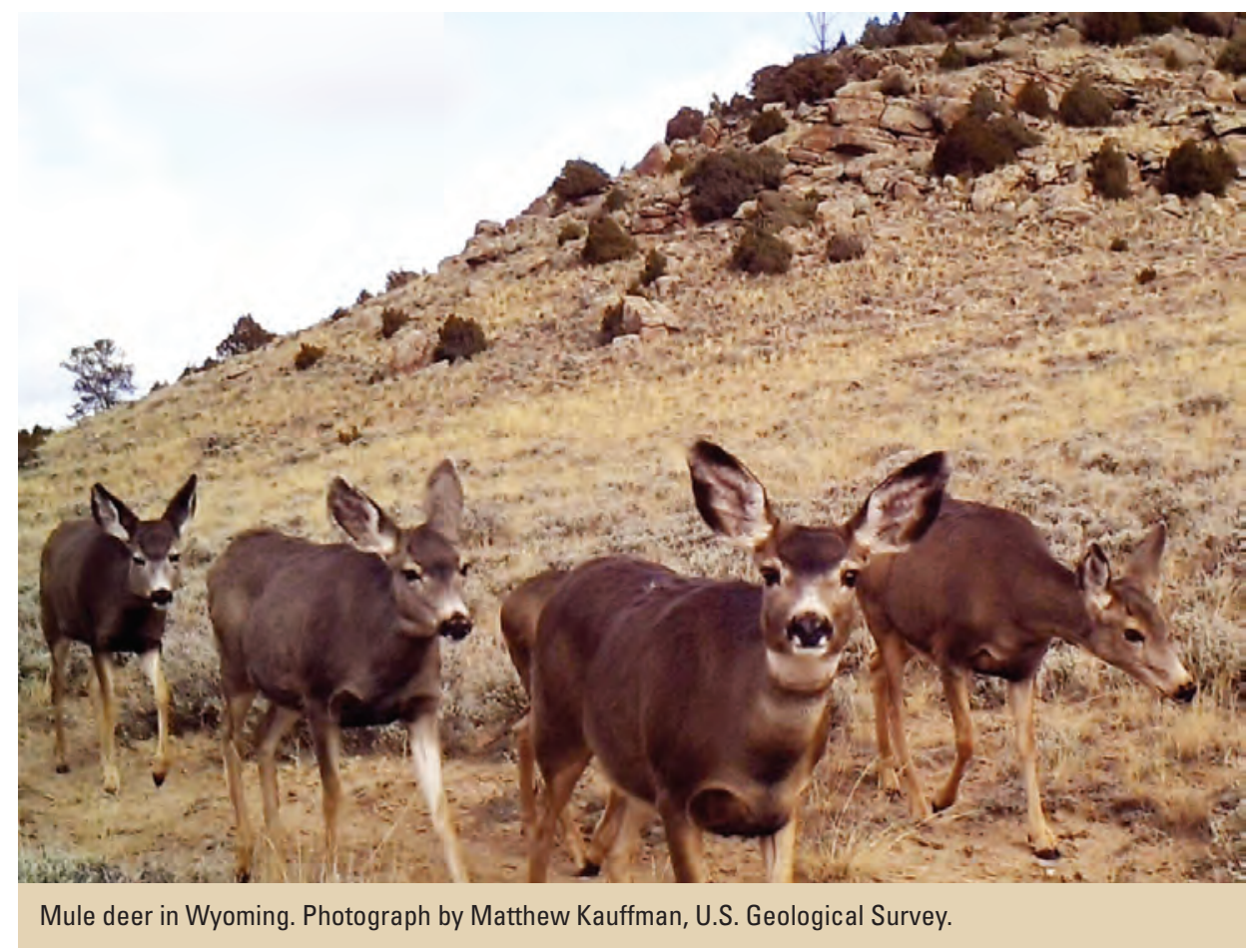

Sawyer, H., Middleton, A.D., Hayes, M.M., Kauffman, M.J., and Monteith, K.L., 2016, The extra mile-Ungulate migration distance alters the use of seasonal range and exposure to anthropogenic risk: Ecosphere, v. 7, no. 10, article e01534, 11 p., https://doi.org/10.1002/ecs2.1534.

Wyckoff, T.B., Sawyer, H., Albeke, S.E., Garman, S.L., and Kauffman, M.J., 2018, Evaluating the influence of energy and residential development on the migratory behavior of mule deer: Ecosphere, v. 9, no. 2, article e02113, 13 p., https://doi.org/10.1002/ecs2.2113. 


\section{Interactions of Phenology, Grazing, Hunting, and Prescribed Fire on Elk in Southwestern Wyoming}

In southwestern Wyoming, land managers are interested in understanding the patterns of elk (Cervus elaphus canadensis) migration, habitat use, and calving areas in the sagebrush ecosystem. USGS scientists are evaluating the likely triggers for initiation of fall migration, changes in the timing of forage during time periods crucial to elk reproduction (fall and spring), and the influence of prescribed fire, grazing, land cover, and other management activities on habitat use. This effort is leading to the identification of migration corridors, important calving areas, shifts in forage that correlate with population size, and environmental factors relevant to elk movements and habitat use that will inform future management of this important game species.

\section{Contact}

Tabitha A. Graves, USGS Northern Rocky Mountain Science Center; tgraves@usgs.gov; 406-589-6645

\section{Sage-Grouse as an Umbrella Species for Nongame Species of Concern in Wyoming}

A common assumption of conservation practitioners in the Western United States is that the greater sage-grouse is an umbrella species for other co-occurring wildlife. This idea, however, has not yet been empirically examined. In particular, the types of species for which sage-grouse may be an appropriate umbrella and at which spatial scales remain unclear. In Wyoming, USGS scientists are modeling overlap between suitable habitat for 52 nongame sagebrush species of conservation concern in lands managed under the Wyoming Governor's Core Area Strategy. Nongame bird abundance and reproductive success is being quantified across gradients in sage-grouse habitat quality, and before and after habitat treatments (mowing) designed to augment sage-grouse brood-rearing habitat. This research aims to inform land management that uses sage-grouse as an umbrella species, and can help fine-tune other actions needed for species that are not covered under this approach.

\section{Contact}

Anna D. Chalfoun, USGS Wyoming Cooperative Fish and Wildlife Research Unit; achalfoun@usgs.gov; 307-766-6966

\section{Publications}

Carlisle, J.D., Chalfoun, A.D., Smith, K.T., and Beck, J.L., 2018, Nontarget effects on songbirds from habitat manipulation for greater sage-grouse-Implications for the umbrella species concept: The Condor, Ornithological Applications, v. 120, no. 2, p. 439-455, https://doi.org/10.1650/CONDOR-17-200.1.

Carlisle, J.D., Keinath, D.A., Albeke, S.E., and Chalfoun, A.D., 2018, Identifying holes in the greater sage-grouse conservation umbrella: The Journal of Wildlife Management, v. 82, no. 5, p. 948-957, https://doi.org/10.1002/ jwmg.21460.

Carlisle, J.D., Stewart, D.R., and Chalfoun, A.D., 2018, An invertebrate ecosystem engineer under the umbrella of sage-grouse conservation: Western North American Naturalist, v. 77, no. 4, p. 450-463, https://doi.org/10.3398/064.077.0406.

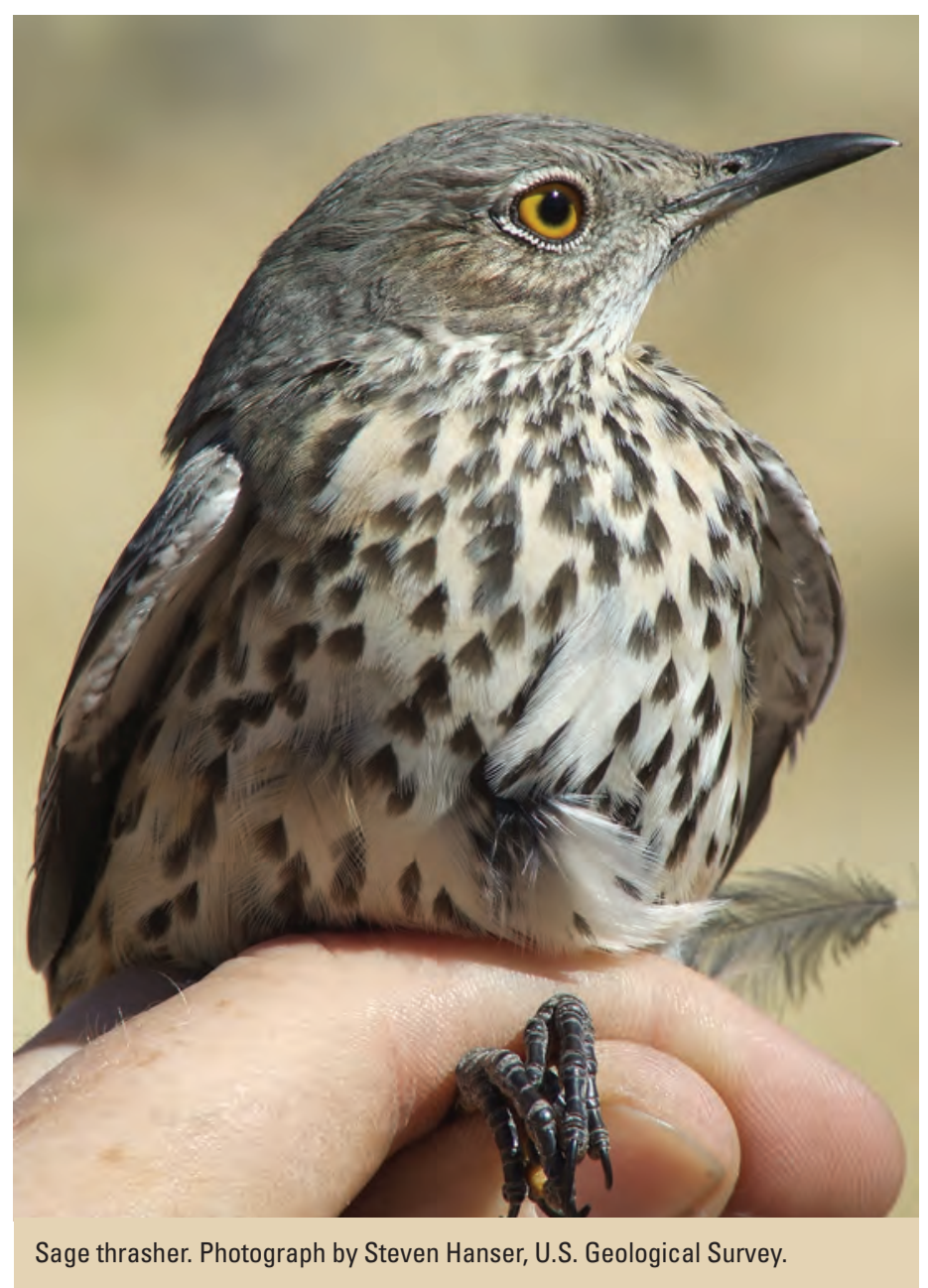




\section{Evaluating Biodiversity of Sagebrush-Dependent Species Within Sage-Grouse Habitat: An Example From the Wyoming Basins}

Concern for declining greater sage-grouse populations has prompted an unprecedented effort by Federal, State, and private stakeholders to implement large-scale habitat management actions and identify priority areas for conservation. Given the dependency of this species on sagebrush-dominated habitat, it is likely that these sage-grouse conservation efforts could benefit other obligate sagebrush species and the ecosystems on which they depend. USGS and CSU scientists and partners are using a modeling approach to evaluate the conservation benefits of sage-grouse to other species of conservation concern within the sagebrush biome. Across the greater Wyoming Basin's sagebrush landscape (Hanser and others, 2011), they are (1) identifying biodiversity hotspots for sagebrush obligate and associated vertebrate species of conservation concern, (2) evaluating the degree of overlap with sage-grouse priority habitats and conservation areas, and (3) evaluating the degree to which sage-grouse core areas in Wyoming capture vertebrate species biodiversity hotspots within the sagebrush biome.

\section{Contact}

Cameron L. Aldridge, Colorado State University, in cooperation with USGS Fort Collins Science Center; aldridgec@usgs.gov; 970-226-9433

\section{The Influence of Climatic Conditions on Reproduction of Sagebrush-Dependent Birds: Implications for Climate Vulnerability Assessments and Habitat Prioritization Efforts}

Birds in aridlands of western North America are some of the fastest declining bird species, and they are among those expected to be most affected by changing climate. USGS researchers are evaluating the reproductive vital rates of sagebrush songbirds in relation to climatic variation by leveraging several large existing datasets of nesting observations from Montana and Wyoming, archived weather station data, and gridded climate datasets. To further examine whether particular landscapes and (or) microhabitats may confer more protection in the face of increasingly more extreme weather events expected with climate change, habitat data collected remotely and at nests will be incorporated into climatic response models. Novel field efforts have also been designed to assess whether microhabitats at nests buffer ambient conditions and the associated fitness consequences. This project will inform managers about songbird species that may be vulnerable to potential changes in climate.

\section{Contact}

Anna D. Chalfoun, USGS Wyoming Cooperative Fish and Wildlife Research Unit; achalfoun@usgs.gov; 307-766-6966

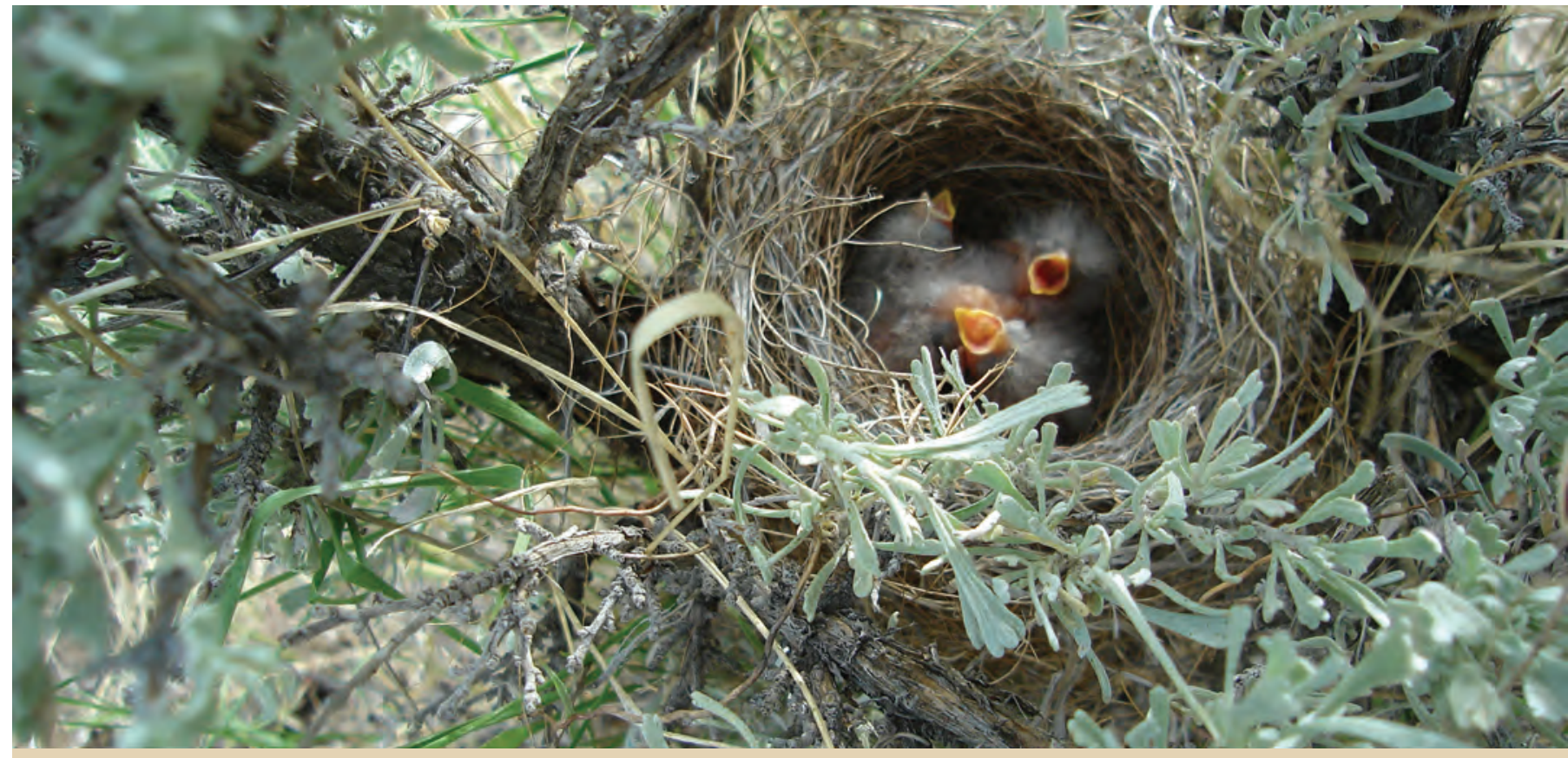

Brewer's sparrow nestlings. Photograph by Steven Hanser, U.S. Geological Survey. 


\section{Developing Regional and Local Decision Support Tools for Sagebrush and Grassland Ecosystems in Northeastern Wyoming}

In and around the Thunder Basin National Grassland of northeastern Wyoming, USGS and CSU scientists and other partners are developing monitoring tools to be directly applied to inform on-the-ground conservation decision making. Using data collected by the Bird Conservancy of the Rockies through their Integrated Monitoring of Bird Conservation Regions program, the monitoring tools will be built using indices generated by combining abundance estimates of individual songbird species reliant on sagebrush or grassland habitat types. Initial focus is on developing regional monitoring tools that evaluate bird community responses to broader scale habitat attributes such as agricultural land configuration and energy development. These regional-scale tools will provide the foundation for developing site-specific monitoring tools to directly evaluate the response of bird communities to conservation actions and agricultural practices implemented through conservation programs administered by local and nongovernmental organizations.

\section{Contacts}

Cameron L. Aldridge, Colorado State University, in cooperation with USGS Fort Collins Science Center; aldridgec@usgs.gov; 970-226-9433

David Edmunds, Colorado State University, in cooperation with USGS Fort Collins Science Center; dedmunds@usgs.gov; 970-226-9180

\section{Fire-Cheatgrass Cycle Effects on Sagebrush Ecosystem Engineers}

Burrowing mammals, such as American badgers (Taxidea taxus) and Piute ground squirrels (Urocitellus mollis), modify soil properties through digging and provide subterranean habitat for other species. USGS and university scientists evaluated how fire, cheatgrass, and other environmental factors influence the occupancy and abundance of these ecosystem engineers within a sagebrush ecosystem. Squirrel abundance was negatively associated with cheatgrass, fire frequency, and shrub cover-characteristics influenced by the fire-cheatgrass cycle. Badgers occupied areas where ground squirrels were present, as they are important badger prey. This study highlights how the fire-cheatgrass cycle influences a predator-prey system by directly affecting prey and by indirectly affecting predators. Land management strategies, such as establishing native bunchgrasses after wildfire, may benefit burrowing prey species and help preserve the trophic functions they provide.

\section{Contact}

David S. Pilliod, USGS Forest and Rangeland Ecosystem Science Center; dpilliod@usgs.gov; 208-426-5202

\section{Publication}

Holbrook, J.D., Arkle, R.S., Rachlow, J.L., Vierling, K.T., Pilliod, D.S., and Wiest, M.M., 2016, Occupancy and abundance of predator and prey-Implications of the fire-cheatgrass cycle in sagebrush ecosystems: Ecosphere, v. 7, no. 6, article e01307, 21 p., https://doi.org/10.1002/ecs2.1307.

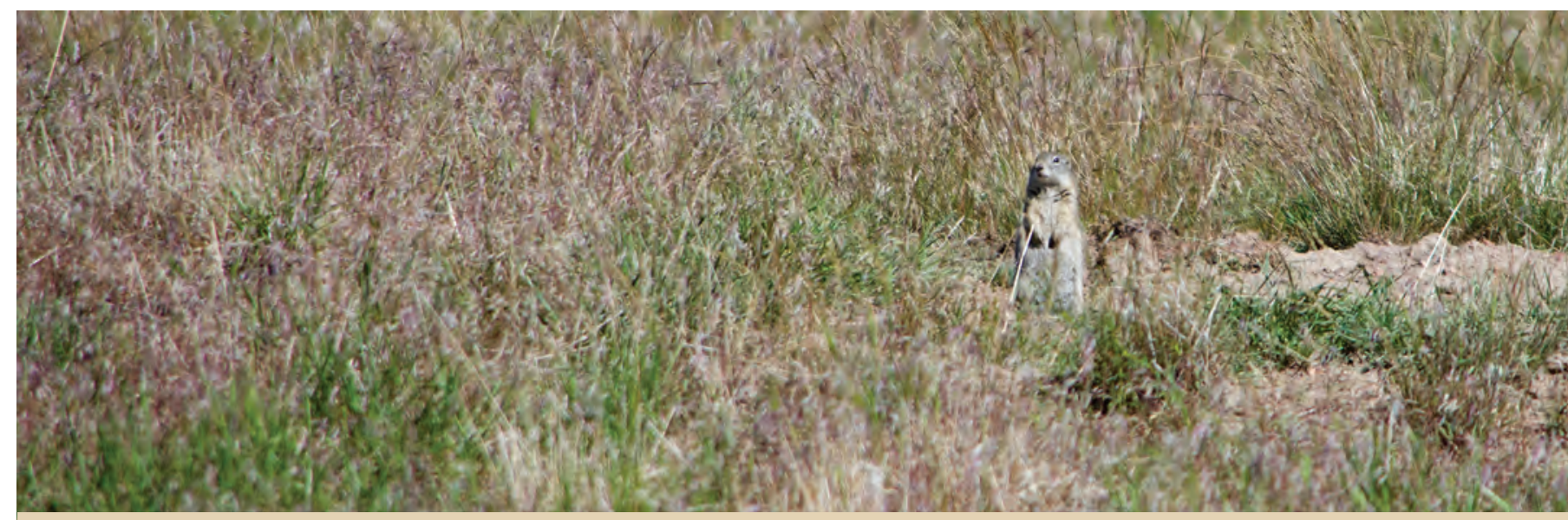




\section{Influence of Harvester Ants in Burned Areas Invaded by Exotic Annual Grasses}

Sagebrush ecosystems are experiencing vegetation-state changes because of fire and invasion by exotic annual grasses. Harvester ants (Pogonomyrmex and Messor spp.) modify their habitat by consuming seeds, removing vegetation, and altering soil properties and nutrients. To study the effects of the changes affecting the sagebrush ecosystems on harvester ants, USGS and university scientists sampled sites across the northern Great Basin where shrublands were replaced by grasslands after fire. Results suggest that harvester ants can increase habitat heterogeneity and create "islands of influence" within sagebrush shrublands, even after fire and invasion by nonnative grasses, and that harvester ants may be one of the few winners among a myriad of losers linked to vegetation-state changes within sagebrush ecosystems.

\section{Contact}

David S. Pilliod, USGS Forest and Rangeland Ecosystem Science Center; dpilliod@usgs.gov; 208-426-5202

\section{Publications}

Gosselin, E.N., Holbrook, J.D., Huggler, K., Brown, E., Vierling, K.T., Arkle, R.S., and Pilliod, D.S., 2016, Ecosystem engineering of harvester ants -Effects on vegetation in a sagebrushsteppe ecosystem: Western North American Naturalist, v. 76, no. 1, p. 82-89, https://doi.org/10.3398/064.076.0109.

Holbrook, J.D., Pilliod, D.S., Arkle, R.S., Rachlow, J.L., Vierling, K.T., and Wiest, M.M., 2016, Transition of vegetation states positively affects harvester ants in the Great Basin, United States: Rangeland Ecology \& Management, v. 69, no. 6, p. 449-456, https://doi.org/10.1016/j.rama.2016.06.009.

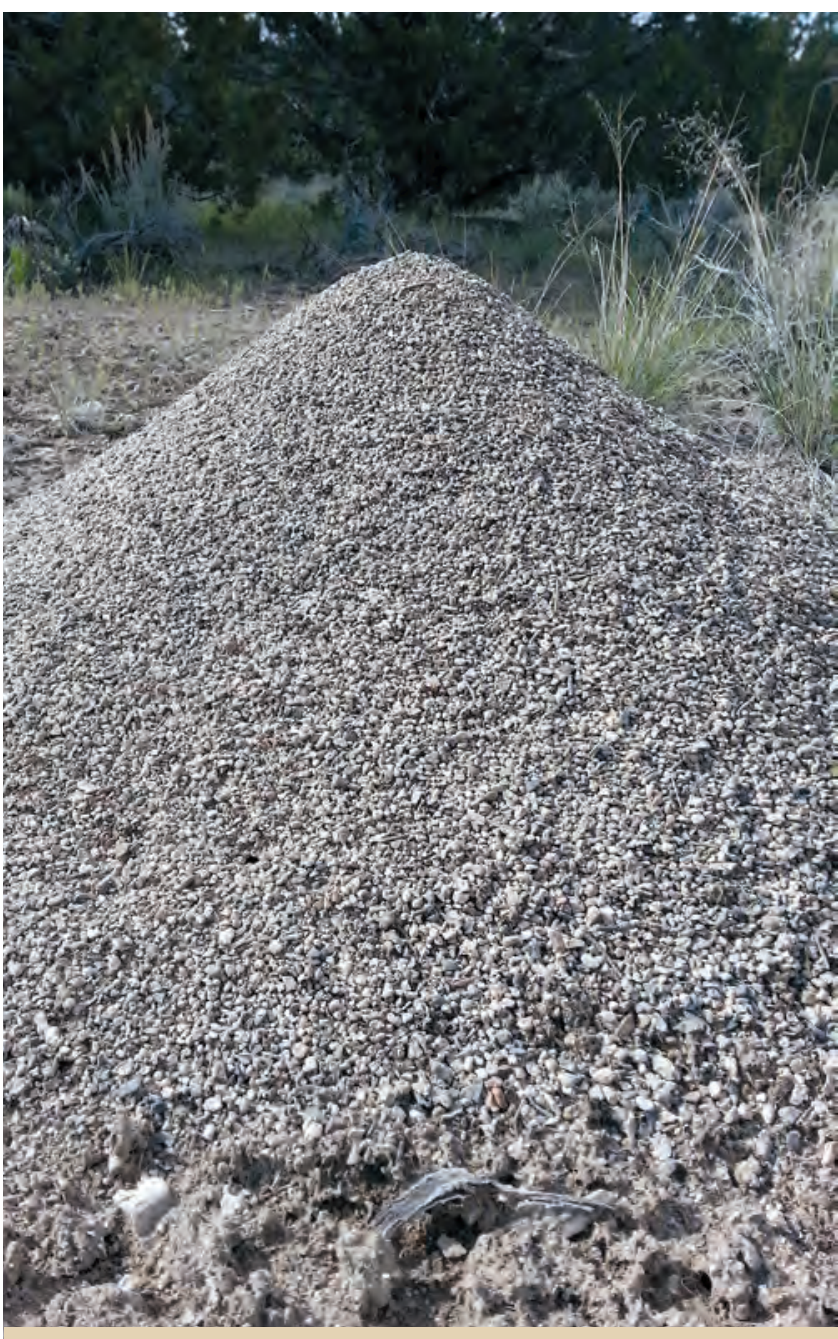

Harvester ant mound in Utah. Photograph by Steven Hanser, U.S. Geological Survey.

\section{Smart Energy Development in the Sagebrush Ecosystem}

The USGS is developing science and decision support tools to inform policy and management decisions about various aspects of the energy development life cycle. This is particularly important with ongoing demands for limited natural resources, and the need to be cost effective and to make decisions at the broader landscape scale. USGS scientists are working with Federal, State, and industry partners to develop the natural resource knowledge, management tools, risk assessments, and scenario planning that will form the scientific foundation needed to target areas of high resource potential and low environmental concern and inform effective development.

\section{Contact}

Steven E. Hanser, USGS Ecosystems Mission Area; shanser@usgs.gov; 703-648-4054

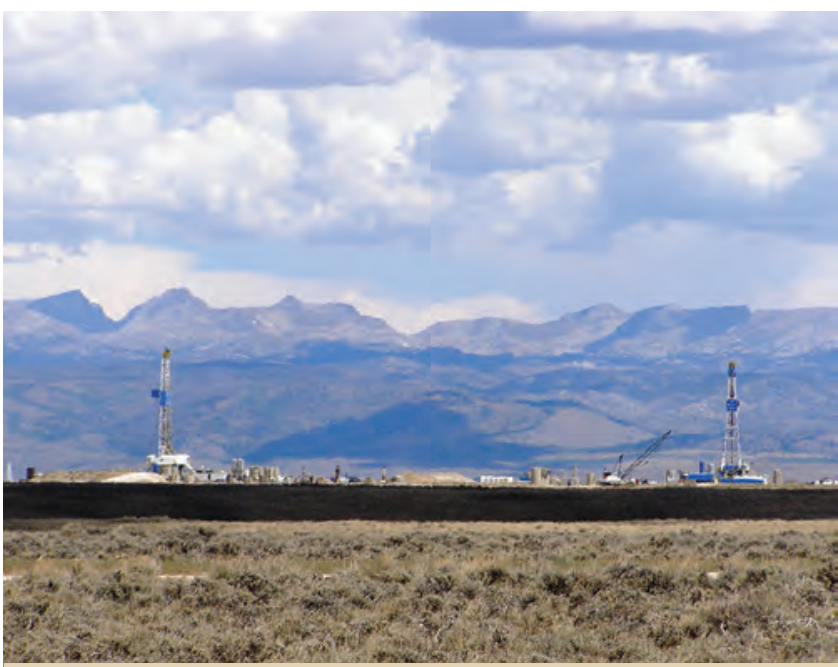

Oil and gas development near the Wind River Range in Wyoming. Photograph from Bureau of Land Management. 


\section{Evaluating Reclamation Success Following Oil and Gas Development}

USGS scientists developed a new tool — the disturbance automated reference toolset (DART) — to provide regional assessments of land recovery following oil and gas drilling activities. This new tool was developed to help resource managers make informed decisions for future well pad development. The tool incorporates satellite imagery, digital soil mapping, predictive ecological modeling, and field assessments to evaluate vegetation recovery following well pad abandonment. Scientists used the tool to study 1,800 well pads in Colorado, New Mexico, and Utah, comparing vegetation cover of the abandoned sites to surrounding undisturbed areas with roughly equivalent climate, soil, topography, and management histories. Findings showed that most abandoned oil and gas pads in the study were characterized by more bare ground and less vegetation than surrounding undisturbed areas, even more than 9 years after well abandonment. Differing recovery rates across environmental gradients and land stewardship suggest that these findings can be useful for identifying conditions that may promote or hamper pad recovery.

\section{Contact}

Michael C. Duniway, USGS Southwest Biological Science Center; mduniway@usgs.gov; 435-719-2330

\section{Publications}

Nauman, T.W., and Duniway, M.C., 2016, The automated reference toolset-A soil-geomorphic ecological potential matching algorithm: Soil Science Society of America Journal, v. 80, no. 5, p. 1317-1328, https://doi.org/10.2136/sssaj2016.05.0151.

Nauman, T.W., Duniway, M.C., Villarreal, M.L., and Poitras, T.B., 2017, Disturbance automated reference toolset (DART)— Assessing patterns in ecological recovery from energy development on the Colorado Plateau: Science of the Total Environment, v. 584-585, p. 476-488, https://doi.org/10.1016/j.scitotenv.2017.01.034.

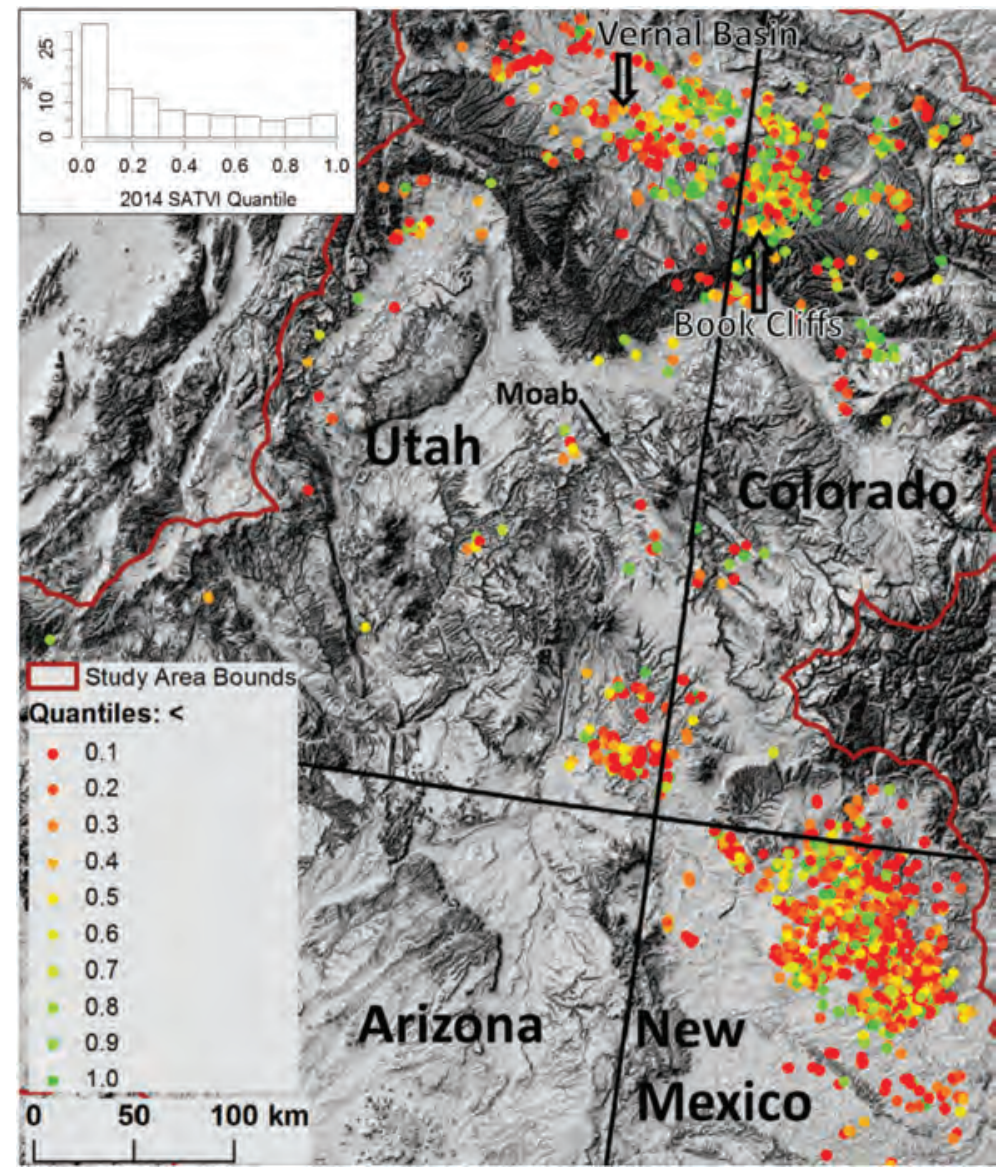

Waller, E.K., Villarreal, M.L., Poitras, T.B., Nauman, T.W., and Duniway, M.C., 2018, Landsat time series analysis of fractional plant cover changes on abandoned energy development sites: International Journal of Applied Earth Observation and Geoinformation, v. 73, p. 407-419, https://doi.org/10.1016/j.jag.2018.07.008.

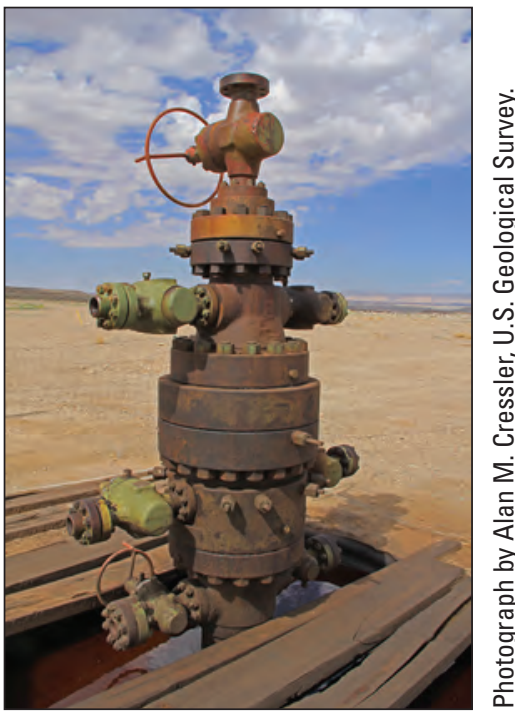

Left: Map showing spatial distribution and histogram of well-pad recovery quantiles obtained using the disturbance automated reference toolset (DART). Points in red have lower vegetation cover signal and those in green have higher cover relative to reference areas (from Nauman and others, 2017). Right: Photograph of shut in gas well on Bureau of Land Management lands in Grand County, Utah. 


\section{Using Long-Term Remote Sensing and an Automated Reference Toolset To Estimate and Predict Post-Development Recovery Potential}

Predicting recovery rates of vegetation following disturbance could help inform future placement of energy development to minimize environmental impacts. In this study, USGS scientists are using a time-varying approach to monitor and predict recovery of sagebrush ecosystems following disturbance. Within areas where the DART (see previous project) is currently developed in the WLCI study area, scientists will identify suitable reference sites near well pads and then characterize vegetation and bare ground cover at reference and disturbed sites at 2- to 5-year intervals from 1985 to 2015. These data will enable modeling to determine how recovery potential changes over time according to differences in soils, weather, and well pad characteristics. This information and resulting spatial data can help inform future development and planning processes.

\section{Contacts}

Adrian P. Monroe, Colorado State University, in cooperation with USGS Fort Collins Science Center; amonroe@usgs.gov; 970-226-9122

Michael C. Duniway, USGS Southwest Biological Science Center; mduniway@usgs.gov; 435-719-2330

Cameron L. Aldridge, Colorado State University, in cooperation with USGS Fort Collins Science Center; aldridgec@usgs.gov; 970-226-9433

\section{Quantifying the Potential Effects of Energy Development on Wildlife and Ecosystem Services}

Energy resources are critical for a prosperous and secure nation, and a clear understanding of the potential effects of energy resource extraction is necessary for efficient and minimally impactful extraction. USGS scientists are developing and applying probabilistic models to evaluate the potential effects of energy development on landscapes, wildlife, and ecosystem services, building from the geology-based USGS assessments of undiscovered petroleum resources. Ongoing projects include (1) the development of the R package energySim and applying the model to understand potential surface disturbance associated with fully extracting technically recoverable continuous petroleum resources across the United States and (2) using the energy footprint model to evaluate the effects of sage-grouse core area policy on landscape patterns and wildlife habitat and to understand potential changes in sediment erosion under alternative energy development scenarios.

\section{Contacts}

Monica A. Dorning, USGS Geosciences and Environmental Change Science Center; mdorning@usgs.gov; 352-264-3499

Seth S. Haines, USGS Central Energy Resources Science Center; shaines@usgs.gov; 303-236-5709

Jay E. Diffendorfer, USGS Geosciences and Environmental Change Science Center; jediffendorfer@usgs.gov; 303-236-5369

\section{Publications}

Dorning, M.A., Garman, S.L., Diffendorfer, J.E., Semmens, D.J., Hawbaker, T.J., and Bagstad, K.J., 2017, Oil and gas development influences big-game hunting in Wyoming: The Journal of Wildlife Management, v. 81, no. 3, p. 379-392, https://doi.org/10.1002/jwmg.21205.

Garman, S.L., 2017, A simulation framework for assessing physical and wildlife impacts of oil and gas development scenarios in southwestern Wyoming: Environmental Modeling \& Assessment, v. 23, no. 1, p. 39-56, https://doi.org/10.1007/s10666-017-9559-1.

Haines, S.S., Diffendorfer, J.E., Balistrieri, L., Berger, B., Cook, T., DeAngelis, D., Doremus, H., Gautier, D.L., Gallegos, T., Gerritsen, M., Graffy, E., Hawkins, S., Johnson, K.M., Macknick, J., McMahon, P., Modde, T., Pierce, B., Schuenemeyer, J.H., Semmens, D., Simon, B., Taylor, J., and Walton-Day, K., 2014, A framework for quantitative assessment of impacts related to energy and mineral resource development: Natural Resources Research, v. 23, no. 1, p. 3-17, https://doi.org/10.1007/s11053-013-9208-6.

Martinez, C., 2017, energySim—An R package: U.S. Geological Survey software release, https://doi.org/10.5066/F7X34VZF. 


\section{Greater Sage-Grouse Responses to Changes in Precipitation and Temperature and Future Energy Development in Wyoming}

Landscape changes in the form of future oil and gas development and precipitation and temperature changes are expected to impact future greater sage-grouse populations in southwestern Wyoming, yet little is known about the potential magnitudes of these effects. In southwestern Wyoming, USGS and CSU scientists and colleagues are simulating sage-grouse responses to future landscape change, including modified habitat selection and behavioral responses, using a time series of planned oil and gas development and climate-induced vegetation changes. The results of this study can help land managers assess the influence of management actions on future sage-grouse abundance, distribution, and trajectories and aid in prioritizing future research and land use planning.

\section{Contacts}

Cameron L. Aldridge, Colorado State University, in cooperation with USGS Fort Collins Science Center; aldridgec@usgs.gov; 970-226-9433

Julie A. Heinrichs, Colorado State University, in cooperation with USGS Fort Collins Science Center; jheinrichs@usgs.gov; 970-226-9149

\section{Publication}

Heinrichs, J.A., Aldridge, C.L., O'Donnell, M.S., and Schumaker, N.H., 2017, Using dynamic population simulations to extend resource selection analyses and prioritize habitats for conservation: Ecological Modelling, v. 359, p. 449-459, https://doi.org/10.1016/j.ecolmodel.2017.05.017.

\section{Mechanisms Underlying Sagebrush-Obligate Songbird Responses to Natural Gas Development}

Extraction for energy resources can have consequences for wildlife populations including sagebrush-obligate songbirds. USGS research initiated in 2008 demonstrated decreased sagebrush songbird (Brewer's sparrow [Spizella breweri], sagebrush sparrow [Artemisiospiza nevadensis], and sage thrasher [Oreoscoptes montanus]) abundance and nesting success with surrounding habitat loss owing to natural gas development in western Wyoming. The predominant source of nest losses was predation, and subsequent 24-hour infrared video camera data revealed that the main nest predators were rodents (deer mice [Peromyscus maniculatus], chipmunks [Tamias spp.], and ground squirrels [Spermophilus spp.]). The abundance of most rodent species increased with natural gas development. Current research is focused on testing alternative hypotheses for the rodent distribution patterns. Understanding the mechanisms underlying wildlife responses to energy development and other forms of humaninduced habitat change are critical to informing targeted and effective management regimes.

\section{Contact}

Anna D. Chalfoun, USGS Wyoming Cooperative Fish and Wildlife Research Unit; achalfoun@usgs.gov; 307-766-6966

\section{Publications}

Hethcoat, M.G., and Chalfoun, A.D., 2015a, Energy development and avian nest survival in Wyoming, USA - A test of a common disturbance index: Biological Conservation, v. 184, p. 327-334, https://doi.org/10.1016/j.biocon.2015.02.009.

Hethcoat, M.G., and Chalfoun, A.D., 2015b, Towards a mechanistic understanding of human-induced rapid environmental change-A case study linking energy development, nest predation and predators: Journal of Applied Ecology, v. 52, no. 6, p. 1492-1499, https://doi.org/10.1111/1365-2664.12513.

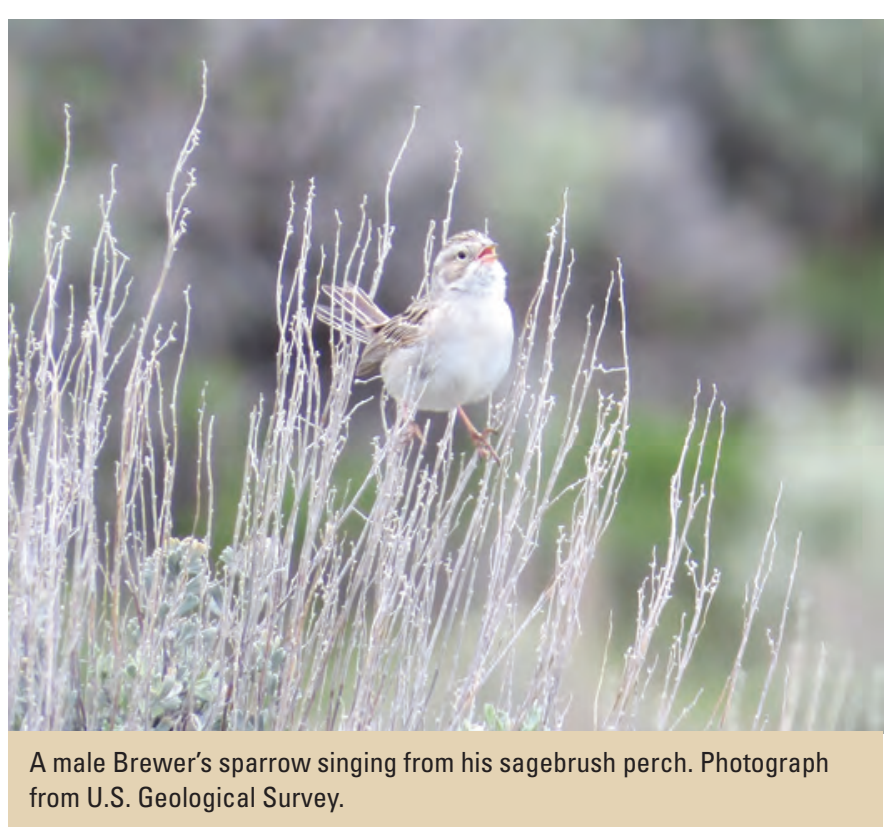




\section{Pygmy Rabbit Distribution and Abundance Relative to Ongoing Energy Development in Wyoming}

Pygmy rabbits (Brachylagus idahoensis) rely year-round on sagebrush for both food and cover and are sensitive to oil and gas development. They are a species of conservation concern in several States and have been petitioned for listing under the Endangered Species Act across their range. In Wyoming, USGS scientists are investigating the influence of oil and gas development on pygmy rabbit populations. This research will help determine the distribution of pygmy rabbit habitat relative to ongoing oil and gas well development and how far from the nearest well pad, road, or pipelines pygmy rabbit presence and abundance may be affected. This information can help inform the development of future oil and gas fields and reduce the effects of disturbance on pygmy rabbits and other sagebrush obligate wildlife. The scientists anticipate expanding this work to other states where pygmy rabbits and energy development co-occur to help future energy development and efforts to manage this sagebrush-obligate species.

\section{Contact}

Stephen S. Germaine, USGS Fort Collins Science Center; germaines@usgs.gov; 970-226-9107

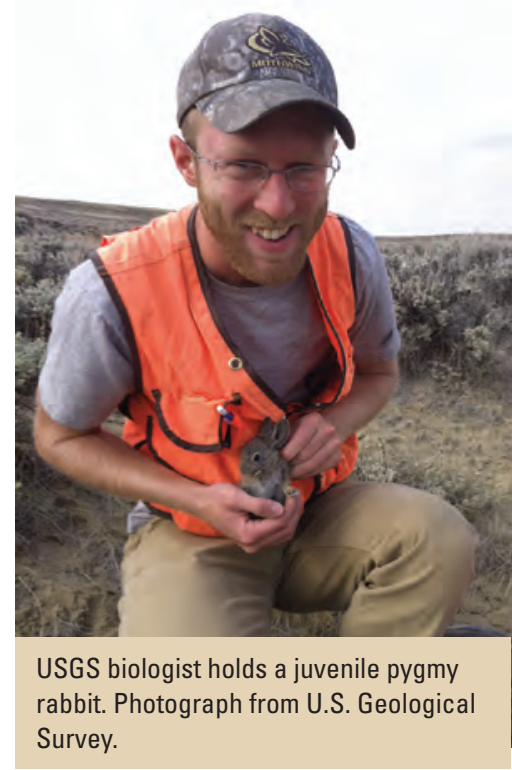

\section{Publications}

Germaine, S.S., Carter, S.K., Ignizio, D.A., and Freeman, A.T., 2017, Relationships between gas field development and the presence and abundance of pygmy rabbits in southwestern Wyoming: Ecosphere, v. 8, no. 5, article e01817, 19 p., https://doi.org/10.1002/ecs2.1817.

Germaine, S., Ignizio, D., Keinath, D., and Copeland, H., 2014, Predicting occupancy for pygmy rabbits in Wyoming-An independent evaluation of two species distribution models: Journal of Fish and Wildlife Management, v. 5, no. 2, p. 298-314, https://doi.org/10.3996/022014-JFWM-016.

\section{Effects of Livestock Grazing on Greater Sage-Grouse}

Cattle grazing may be the most common land use within sage-grouse habitat. The USGS is working with ranchers and university and agency collaborators to quantify the effects of cattle grazing on sage-grouse through a suite of replicated landscape-scale experiments. This research is evaluating the effects of different cattle grazing regimes on survival, site fidelity, habitat selection, chick diet, and reproductive traits of greater sage-grouse. The experimental study uses replicate study sites across Idaho that receive either no grazing, 30- to 40-percent grass offtake during spring only, or 30- to 40 -percent grass offtake during spring and fall. Researchers are also measuring the effects of these grazing treatments on vegetation (sage-grouse habitat features), arthropod abundance, and abundance of other sagebrush steppe birds. This research will inform land management decisions related to the amount and timing of grazing practices that are compatible with sage-grouse habitat needs.

\section{Contact}

Courtney J. Conway, USGS Idaho Cooperative Fish and Wildlife Research Unit; cconway@usgs.gov; 208-885-6176

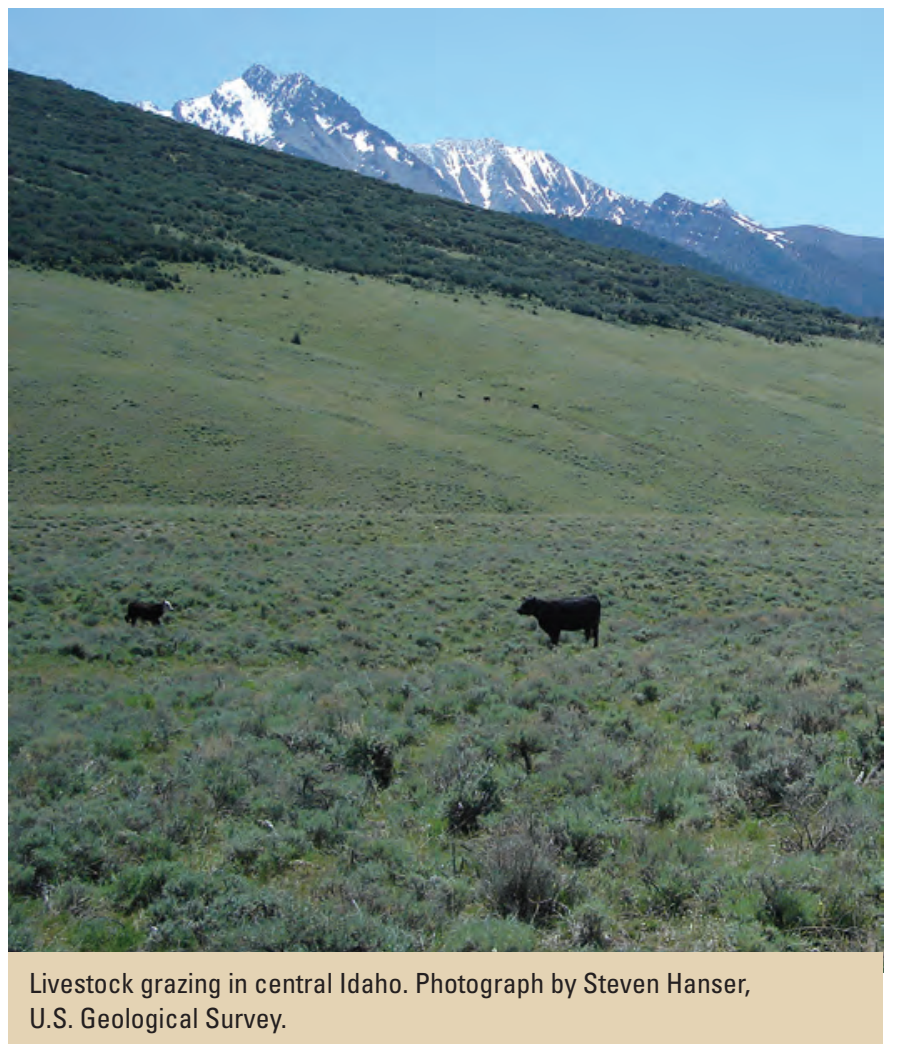




\section{Effects of Invasive Cheatgrass on Sage-Grouse in Nevada}

Invasion of sagebrush shrublands by cheatgrass is one of the primary threats to greater sage-grouse in the Great Basin. The USGS has multiple ongoing studies throughout the Great Basin evaluating the effects of cheatgrass on greater sage-grouse habitat selection and population vital rates. Researchers have measured cheatgrass abundance and height at radio- and GPSmarked sage-grouse locations and at random available locations. In a collaborative effort, the USGS and others are incorporating these cheatgrass data in nest-site selection and nest-survival models for northwestern Nevada. Additionally, researchers are analyzing the effects of cheatgrass on selection and survival within the brood-rearing life phase in study areas across Nevada. This work will provide land managers with information about the relative effects of cheatgrass at multiple life stages, improving the ability to effectively target management and mitigation efforts.

\section{Contacts}

Peter S. Coates, USGS Western Ecological Research Center; pcoates@usgs.gov; 530-669-5073

Michael L. Casazza, USGS Western Ecological Research Center; mike_casazza@usgs.gov; 530-669-5075

\section{Publication}

Lockyer, Z.B., Coates, P.S., Casazza, M.L., Espinosa, S., and Delehanty, D.J., 2015, Nest-site selection and reproductive success of greater sage-grouse in a fire-affected habitat of northwestern Nevada: The Journal of Wildlife Management, v. 79, no. 5, p. 785-797, https://doi.org/10.1002/jwmg.899.

\section{Implications of Anthropogenic Activities on Greater Sage-Grouse Populations in Nevada}

The USGS is conducting research on a broad geographical scale at multiple study sites to understand the long- and shortterm effects of anthropogenic disturbance caused by wind turbines, gold mining, geothermal energy production, hydraulic fracturing for oil, and transmission line development on greater sage-grouse habitat selection, population vital rates, and movement patterns. This research can provide resource managers with information and tools needed to develop guidelines for projects that strive to minimize negative effects on greater sage-grouse.

\section{Contact}

Peter S. Coates, USGS Western Ecological Research Center; pcoates@usgs.gov; 530-669-5073

\section{Effects of Pinyon and Juniper on Sage-Grouse Movement, Distribution, and Survival}

Conifer expansion into sagebrush shrublands is a major threat to sage-grouse habitat. Information is needed to understand the mechanisms leading to the decline and extirpation of sage-grouse in areas of conifer expansion. USGS scientists are using telemetry from multiple field sites across Nevada and northeastern California collected over a 10-year period, coupled with high-resolution conifer maps, to investigate the influences of trees within sagebrush shrubland on sage-grouse distribution and survival. Results from these analyses indicate that encroachment of sparsely distributed conifers into wet, high-elevation productive habitats strongly selected by sage-grouse may be an ecological trap. Increased predation facilitated by trees serving as perch or nest site subsidies for raptors and ravens may explain this finding; subsequent analyses will identify causes and consequences of ecological traps at different sage-grouse life-history phases in relation to pinyon and juniper. This research provides greater understanding of the risk of conifer encroachment into sagebrush habitat to sage-grouse and can help inform conifer removal projects.

\section{Contact}

Peter S. Coates, USGS Western Ecological Research Center; pcoates@usgs.gov; 530-669-5073

\section{Publications}

Coates, P.S., Prochazka, B.G., Ricca, M.A., Gustafson, K.B., Ziegler, P., and Casazza, M.L., 2017, Pinyon and juniper encroachment into sagebrush ecosystems impacts distribution and survival of greater sage-grouse: Rangeland Ecology \& Management, v. 70, no. 1, p. 25-38, https://doi.org/10.1016/j.rama.2016.09.001.

Prochazka, B.G., Coates, P.S., Ricca, M.A., Casazza, M.L., Gustafson, K.B., and Hull, J.M., 2017, Encounters with pinyonjuniper influence riskier movements in greater sage-grouse across the Great Basin: Rangeland Ecology \& Management, v. 70, no. 1, p. 39-49, https://doi.org/10.1016/j.rama.2016.07.004. 


\section{Predation Effects on Sage-Grouse Population Dynamics}

Information about sage-grouse predation is incomplete. The USGS has initiated a large-scale investigation of predation effects and underlying ecological drivers of predation at sites located throughout California and Nevada. Through use of nest videography, avian predator surveys, habitat assessment, geospatial analysis, and telemetry- and GPS-based sage-grouse monitoring, USGS and Idaho State University scientists are evaluating how habitat composition, anthropogenic impacts, and other spatial and temporal processes influence nest predation rates, as well as age- and sex-specific survival rates, and the distribution of predators themselves. Results from these site-level studies help develop sage-grouse management plans aimed at reducing predation impacts on sage-grouse populations.

\section{Contact}

Peter S. Coates, USGS Western Ecological Research Center; pcoates@usgs.gov; 530-669-5073

\section{Publications}

Coates, P.S., Brussee, B.E., Howe, K.B., Gustafson, K.B., Casazza, M.L., and Delehanty, D.J., 2016, Landscape characteristics and livestock presence influence common ravens-Relevance to greater sage-grouse conservation: Ecosphere, v. 7, no. 2, article e01203, 20 p., https://doi.org/10.1002/ecs2.1203.

Coates, P.S., Howe, K.B., Casazza, M.L., and Delehanty, D.J., 2014, Common raven occurrence in relation to energy transmission line corridors transiting human-altered sagebrush steppe: Journal of Arid Environments, v. 111, p. 68-78, https://doi.org/10.1016/j.jaridenv.2014.08.004.

Lockyer, Z.B., Coates, P.S., Casazza, M.L., Espinosa, S., and Delehanty, D.J., 2013, Greater sage-grouse nest predators in the Virginia Mountains of northwestern Nevada: Journal of Fish and Wildlife Management, v. 4, no. 2, p. 242-255, https://doi.org/10.3996/122012-JFWM-110R1.

\section{Raven Density and Management Across the Great Basin}

Resource managers in the Great Basin region have become increasingly concerned about the implications of increasing predation on sage-grouse nest success and seek to understand where ravens occur and why they occur in numbers high enough to be detrimental to sage-grouse. USGS scientists and collaborators are conducting research to inform adaptive management of raven abundance under the broader goal of reducing predator impacts on sage-grouse populations. Initial information products describe establishment of reproducible survey protocols for estimating raven densities in sage-grouse habitats and in sagebrush ecosystems within the broader Great Basin region of the southwestern United States. In a recent publication, scientists generated spatially explicit maps that integrated high raven occurrence based on anthropogenic subsidies with priority sage-grouse habitat across the Great Basin to help inform future management efforts to reduce predation impacts on sage-grouse populations.

\section{Contact}

Peter S. Coates, USGS Western

Ecological Research Center;

pcoates@usgs.gov;

530-669-5073

\section{Publication}

O’Neil, S.T., Coates, P.S., Brussee, B.E., Jackson, P.J., Howe, K.B., Moser, A.M., Foster, L.J., and Delehanty, D.J., 2018, Broad-scale occurrence of a subsidized avian predator-Reducing impacts of ravens on sage-grouse and other sensitive prey: Journal of Applied Ecology, Accepted Article posted July 25, 2018, 33 p., https://doi.org/ 10.1111/1365-2664.13249.

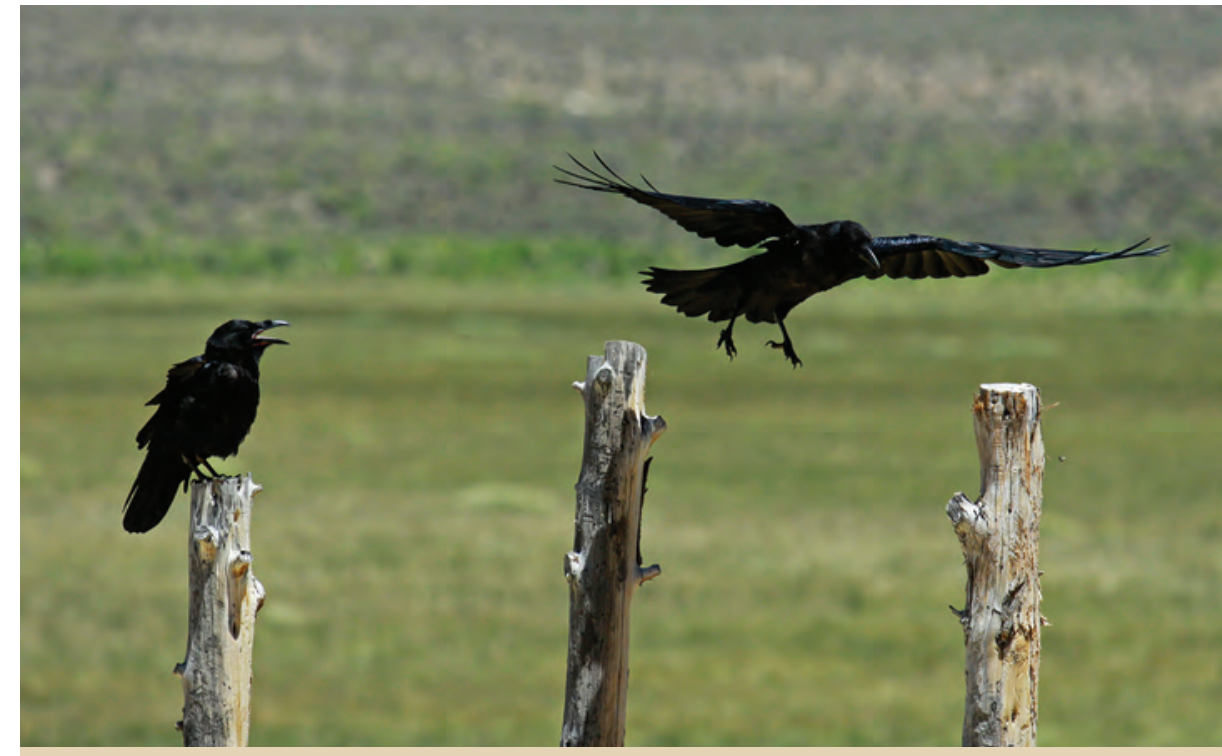

Two common ravens in Nevada. Photograph by Tatiana Gettelman, U.S. Geological Survey. 


\section{Effects of Raven Removal on Nest Survival and Population Growth Rates of Greater Sage-Grouse}

Common raven (Corvus corax) populations are increasing drastically within sagebrush ecosystems, largely as a result of increased anthropogenic resources. Ravens are effective sage-grouse nest predators and increased raven numbers have been shown to decrease sage-grouse nest survival. Wildlife and land management agencies have considered the removal of ravens as an option to increase sage-grouse productivity in many areas throughout the Western United States. However, the effects of raven removal on sage-grouse nest survival, productivity, and population growth rates are unclear. USGS scientists and collaborators are estimating the effects of raven removal on greater sage-grouse population dynamics using 8 to 10 years of telemetry data. This research will help gain better understanding of the effects of ravens on sage-grouse, and inform future management efforts to reduce predation impacts on sage-grouse populations.

\section{Contact}

Peter S. Coates, USGS Western Ecological Research Center; pcoates@usgs.gov; 530-669-5073

\section{Plant Community Composition and Vegetation Structure in Core Sage-Grouse Habitats}

The composition and abundance of plant species in sagebrush ecosystems are important habitat attributes for sage-grouse; however, the combined effects of altered disturbance regimes (for example, fire) and biological invasions (for example, cheatgrass) are affecting plant community dynamics, and these effects are anticipated to accelerate with warmer climatic conditions. The goal of this project is to understand how these interacting change agents may influence plant community dynamics in core sage-grouse habitat areas. USGS scientists and university collaborators are integrating field measurements of plant community structure and soil conditions with ecological simulation models to assess the influence of changing climate and other disturbance regimes on the plant species composition and vegetation structure of sagebrush-dominated ecosystems. Outcomes of the project will help inform potential climate adaptation strategies.

\section{Contact}

John B. Bradford, USGS Southwest Biological Science Center; jbradford@usgs.gov; 928-523-7766

\section{Publications}

Martyn, T.E., Bradford, J.B., Schlaepfer, D.R., Burke, I.C., and Lauenroth, W.K., 2016, Seed bank and big sagebrush plant community composition in a range margin for big sagebrush: Ecosphere, v. 7, no. 10, article e01453, 11 p., https://doi.org/10.1002/ecs2.1453.

Pennington, V.E., Bradford, J.B., Palmquist, K.A., Renne, R., Lauenroth, W.K., in press, Patterns in big sagebrush plant community composition and structure in the Western US: Rangeland Ecology \& Management.

Pennington, V.E., Palmquist, K.A., Bradford, J.B., and Lauenroth, W.K., 2017, Climate and soil texture influence patterns of forb species richness and composition in big sagebrush plant communities across their spatial extent in the western U.S.: Plant Ecology, v. 218, no. 5, p. 957-970, https://doi.org/10.1007/s11258-017-0743-9.

Pennington, V.E., Schlaepfer, D.R., Beck, J.L., Bradford, J.B., Palmquist, K.A., and Lauenroth, W.K., 2016, Sagebrush, greater sage-grouse, and the occurrence and importance of forbs: Western North American Naturalist, v. 76, no. 3, p. 298-312, https://doi.org/10.3398/064.076.0307.

Rottler, C.M., Burke, I.C., Palmquist, K.A., Bradford, J.B., and Lauenroth, W.K., 2017, Current reclamation practices after oil and gas development do not speed up succession or plant community recovery in big sagebrush ecosystems in Wyoming: Restoration Ecology, v. 26, no. 1, p. 114-123, https://doi.org/10.1111/rec.12543.

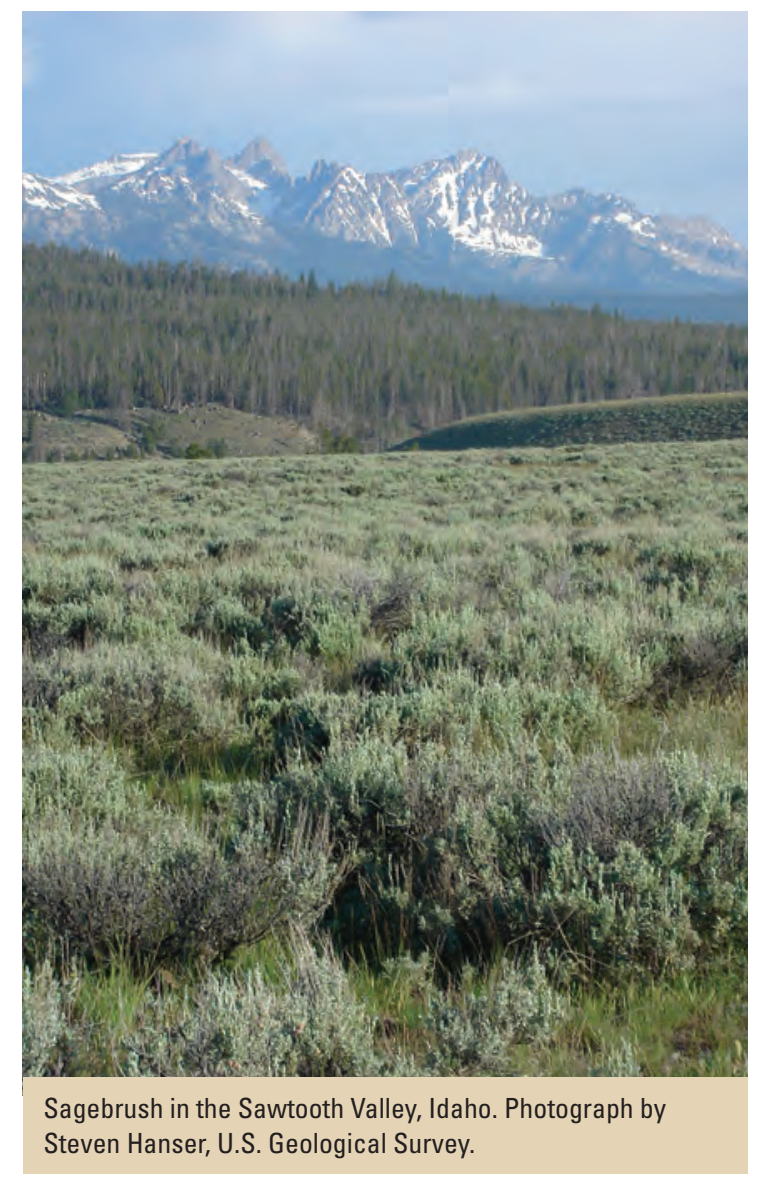




\section{Weather and Climate}

Long-term climate and short-term weather patterns influence vegetation patterns across the sagebrush ecosystem and can influence the outcomes of restoration actions. USGS scientists are conducting research to increase the understanding of variables that control seeding success, inform development of climate adaptation strategies, and improve the collection of locally appropriate seeds for use land management activities.

Sagebrush steppe and approaching storm on Seedskadee National Wildlife Refuge in Wyoming. Photograph from U.S. Fish and Wildlife Service.

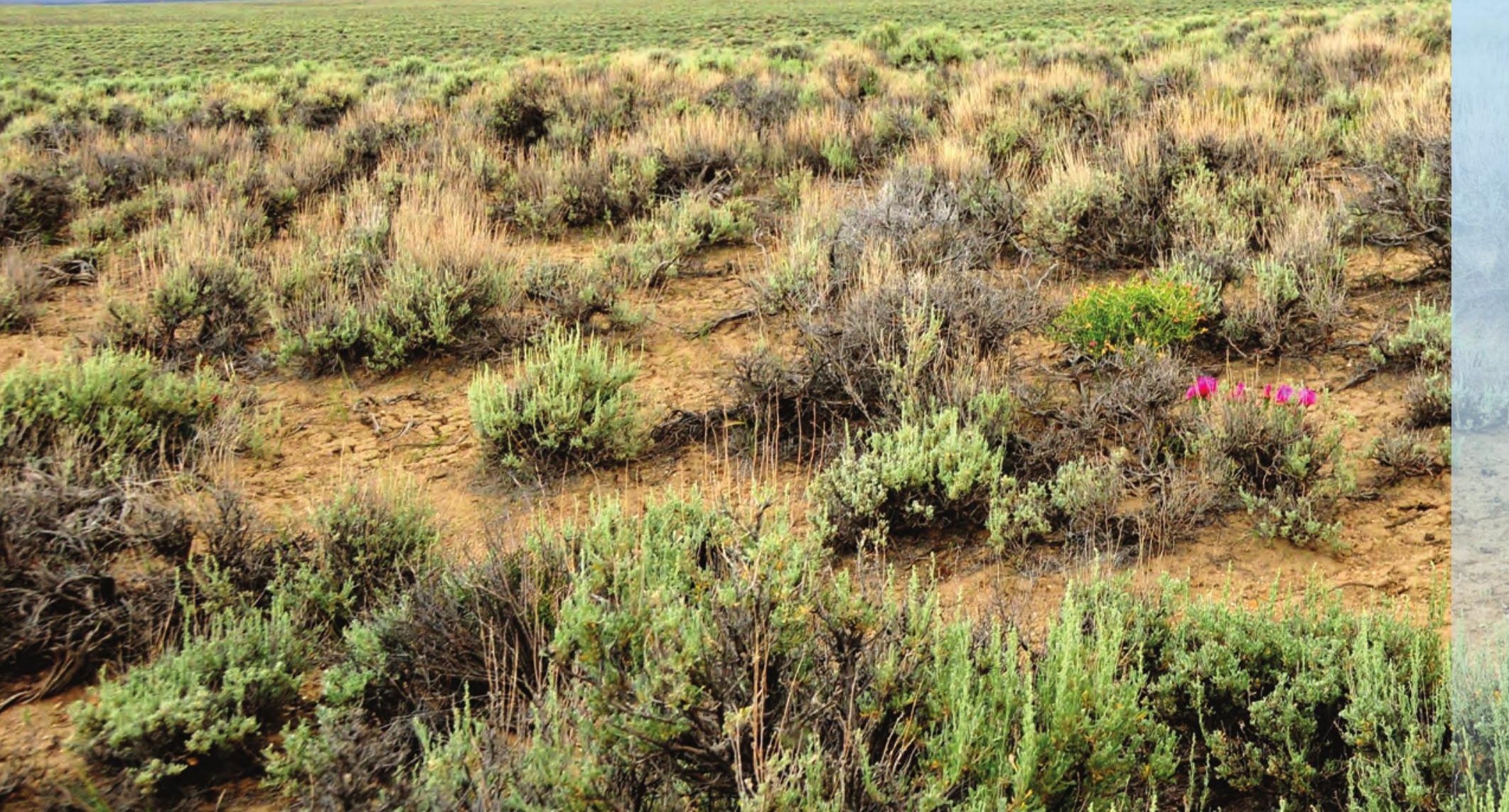




\section{Postfire Wind Erosion and Integration of Weather Prediction Tools}

Postfire soil stability is a major issue for restoration and rehabilitation of big sagebrush habitat owning to variability in weather patterns and potential for wind erosion of exposed soils. The USGS is performing field measurements and simulations to help determine where, when, and why wind and water erosion occurs. This will help managers assess landscape suitability for seeding and will be important for climate vulnerability assessments that use information from advanced weather prediction tools to inform future land treatment implementation.

\section{Contact}

Matthew J. Germino, USGS Forest and Rangeland Ecosystem Science Center; mgermino@usgs.gov; 208-426-3353

\section{Mapping Projected Soil Temperature and Moisture Regimes in a Changing Climate}

The current understanding of resistance of sagebrush ecosystems to invasion by exotic annual grasses and resilience to disturbance has led to maps of vulnerability using estimates of soil temperature and moisture conditions. USGS scientists are projecting those soil temperature and moisture conditions into the future to understand the potential implications of altered precipitation and temperature on sagebrush ecosystems. This project includes three tasks: (1) simulating soil moisture and soil temperature patterns under current conditions across the range of sagebrush (at approximately 10-kilometer resolution), (2) relating those simulations to the distribution of resistance and resilience classes to characterize simulated conditions within each class, and (3) simulating future soil moisture and temperature patterns under a suite of future scenarios to determine how the location of resistance and resilience classes shift in the middle and end of the 21 st century.

\section{Contact}

John B. Bradford, USGS Southwest Biological Science Center; jbradford@usgs.gov; 928-523-7766

\section{Assessing Vulnerability to Drought in Dryland Ecosystems of the Western United States}

Managers of public lands in the Western United States face enormous challenges under recent warmer, drier conditions that are expected to worsen with climate change. This enhanced aridity can lead to permanent degradation of wildlife habitat and ecological services upon which humans depend. To help managers confront these challenges and inform possible future management scenarios meant to address altered temperature and precipitation regimes, USGS scientists have initiated a project that integrates plot- and remote sensing-based vegetation monitoring data collected by management agencies in the Western United States with climate and soil water conditions to determine which types of habitat are vulnerable to drought and climate change, what habitat changes may occur, and where across the landscape these changes will be most pronounced.

\section{Contact}

Seth M. Munson, USGS Southwest Biological Science Center; smunson@usgs.gov; 928-523-7740

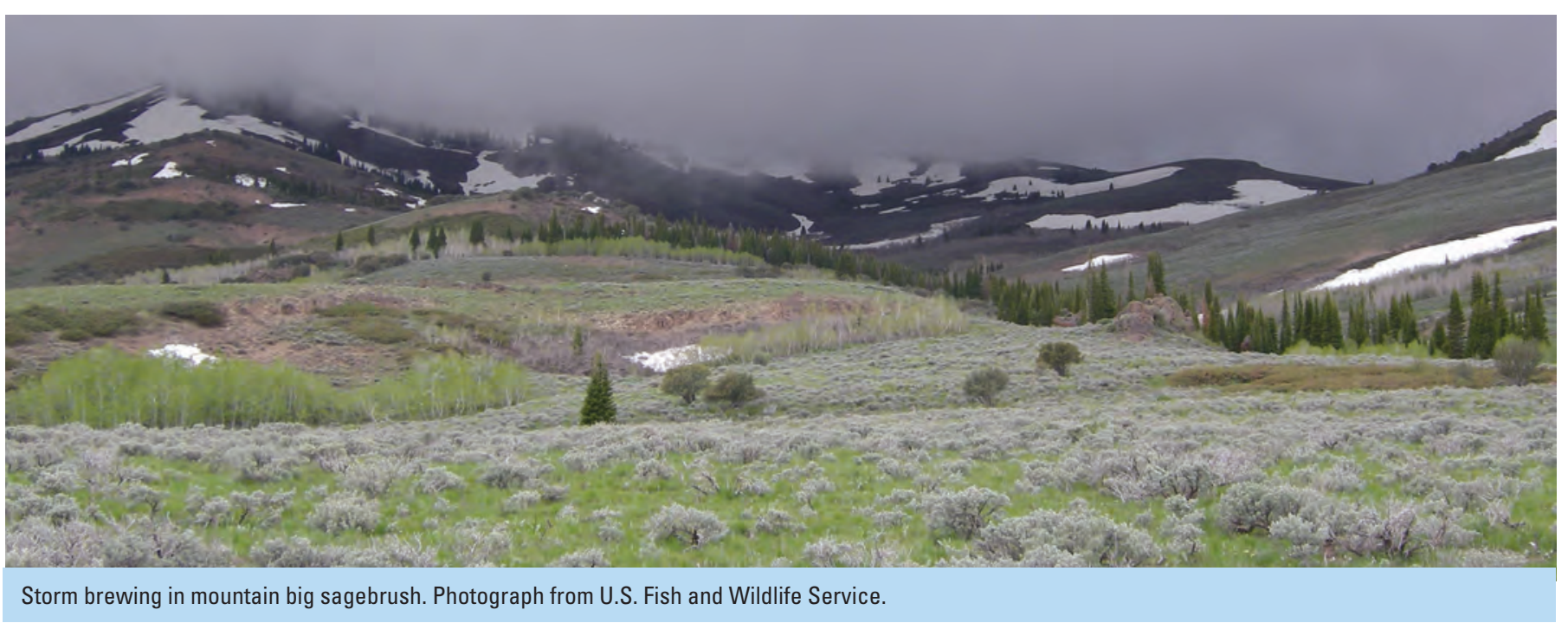




\section{Assessing the Future of Sagebrush Ecosystems}

Sagebrush directly acquires water from the soil, and patterns of available soil moisture that are altered by changes in precipitation and temperature may influence the health and distribution of sagebrush ecosystems. This project characterizes the ecohydrological conditions that support sagebrush ecosystems, identifies how those conditions could change in the future, and assesses the rangewide potential impacts for sage-grouse habitat. In collaboration with university scientists, USGS scientists are (1) quantifying how changes in precipitation and temperature may affect areas suitable to support sagebrush, (2) understanding the controls over sagebrush regeneration (a key limiting life stage for sagebrush), (3) describing uncertainty in species distribution models, and (4) improving the quality and usability of models that identify future suitable sagebrush extent. Outcomes of the project will help inform develop potential climate adaptation strategies.

\section{Contact}

John B. Bradford, USGS Southwest Biological Science Center; jbradford@usgs.gov; 928-523-7766

\section{Publications}

Palmquist, K.A., Bradford, J.B., Martyn, T.E., Schlaepfer, D.R., and Lauenroth, W.K., 2018, STEPWAT2-An individual-based model for exploring the impact of climate and disturbance on dryland plant communities: Ecosphere, v. 9, no. 8, article e02394, 23 p., https://doi.org/10.1002/ecs2.2394.

Palmquist, K.A., Schlaepfer, D.R., Bradford, J.B., and Lauenroth, W.K., 2016a, Mid-latitude shrub steppe plant communities - Climate change consequences for soil water resources: Ecology, v. 97, no. 6, p. 2342-2354, https://doi.org/10.1002/ ecy. 1457.

Palmquist, K.A., Schlaepfer, D.R., Bradford, J.B., and Lauenroth, W.K., 2016b, Spatial and ecological variation in dryland ecohydrological responses to climate change-Implications for management: Ecosphere, v. 7, no. 11, article e01590, 20 p., https://doi.org/10.1002/ecs2.1590.

Schlaepfer, D.R., Lauenroth, W.K., and Bradford, J.B., 2014a, Modeling regeneration responses of big sagebrush (Artemisia tridentata) to abiotic conditions: Ecological Modelling, v. 286, p. 66-77, https://doi.org/10.1016/j.ecolmodel.2014.04.021.

Schlaepfer, D.R., Lauenroth, W.K., and Bradford, J.B., 2014b, Natural regeneration processes in big sagebrush (Artemisia tridentata): Rangeland Ecology \& Management, v. 67, no. 4, p. 344-357, https://doi.org/10.2111/REM-D-13-00079.1.

Schlaepfer, D.R., Taylor, K.A., Pennington, V.E., Nelson, K.N., Martyn, T.E., Rottler, C.M., Lauenroth, W.K., and Bradford, J.B., 2015, Simulated big sagebrush regeneration supports predicted changes at the trailing and leading edges of distribution shifts: Ecosphere, v. 6, no. 1, article 3, 31 p., https://doi.org/10.1890/ES14-00208.1.

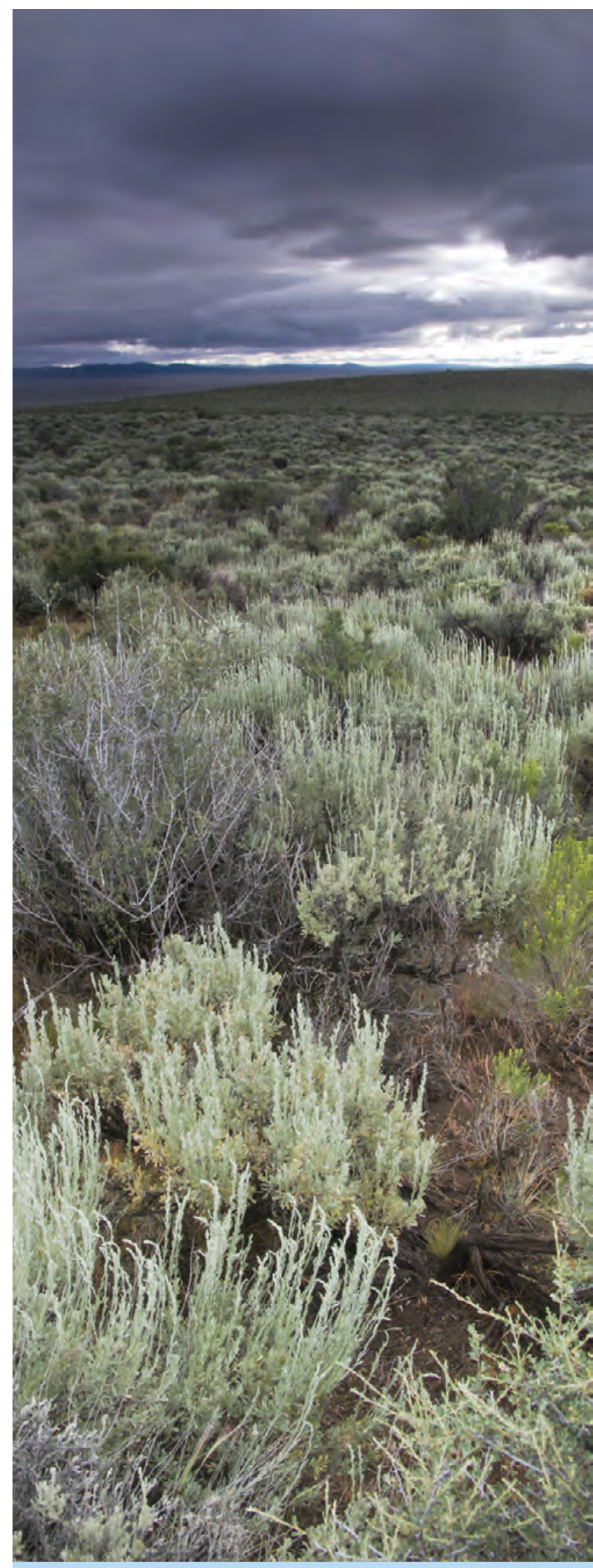

Sagebrush. Photograph from Conservation Media, used with permission. 


\section{Weather-Centric Rangeland Revegetation Planning}

Rehabilitation and restoration of rangelands impacted by invasions of annual weeds are challenging because climate and weather variability affects seed germination, survival and establishment of seedlings, annual weed dynamics, wildfire frequency, and soil stability. In this collaboration, USDA Agricultural Research Service, USGS, and university partners are developing tools to inform revegetation efforts using site-specific weather information from historical observations, seasonal climate forecasts, and climate-change projections. Incorporating climate and weather information into rangeland revegetation planning could reduce management uncertainty, improve understanding of the ecological processes driving succession, and increase the efficiency of rehabilitation and restoration efforts. Seasonal climate forecasts and climate-change projections could improve the cost efficiency of management treatments and help develop mitigation and adaptation strategies for long-term practices.

\section{Contacts}

Matthew J. Germino, USGS Forest and Rangeland Ecosystem Science Center; mgermino@usgs.gov; 208-426-3353

David S. Pilliod, USGS Forest and Rangeland Ecosystem Science Center; dpilliod@usgs.gov; 208-426-5202

\section{Publication}

Hardegree, S.P., Abatzoglou, J.T., Brunson, M.W., Germino, M.J., Hegewisch, K.C., Moffet, C.A., Pilliod, D.S., Roundy, B.A., Boehm, A.R., and Meredith, G.R., 2018, Weather-centric rangeland revegetation planning: Rangeland Ecology \& Management, v. 71, no. 1, p. 1-11, https://doi.org/10.1016/j.rama.2017.07.003.

\section{Understanding Changes in Sagebrush Distribution and Abundance Under Climate Change: Integration of Spatial, Temporal, and Mechanistic Models}

A collaborative research team led by several academic institutions, in partnership with the USGS and CSU, used multiple modeling approaches to evaluate climate change impacts on sagebrush, the dominant plant species on roughly 110 million acres in the Western United States, and a key resource for many endemic wildlife species like sage-grouse. Performance, as measured by change in cover, growth, or recruitment, was predicted to decrease at the warmest sites but increase throughout the cooler portions of sagebrush's range. A sensitivity analysis indicated that sagebrush performance responds more strongly to changes in temperature than precipitation. Most of the uncertainty in model predictions reflected variation among the ecological models, raising questions about the reliability of forecasts based on a single modeling approach. Results of this study highlight the value of a multimodel approach in forecasting climate change impacts and uncertainties and should help land managers to maximize the value of conservation investments.

\section{Contact}

Cameron L. Aldridge, Colorado State University, in cooperation with USGS Fort Collins Science Center; aldridgec@usgs.gov; 970-226-9433

\section{Publication}

Renwick, K.M., Curtis, C., Kleinhesselink, A.R., Schlaepfer, D., Bradley, B.A., Aldridge, C.L., Poulter, B., and Adler, P.B., 2018, Multi-model comparison highlights consistency in predicted effect of warming on a semi-arid shrub: Global Change Biology, v. 24 , no. 1 , p. $424-438$, https://doi.org/10.1111/gcb.13900.

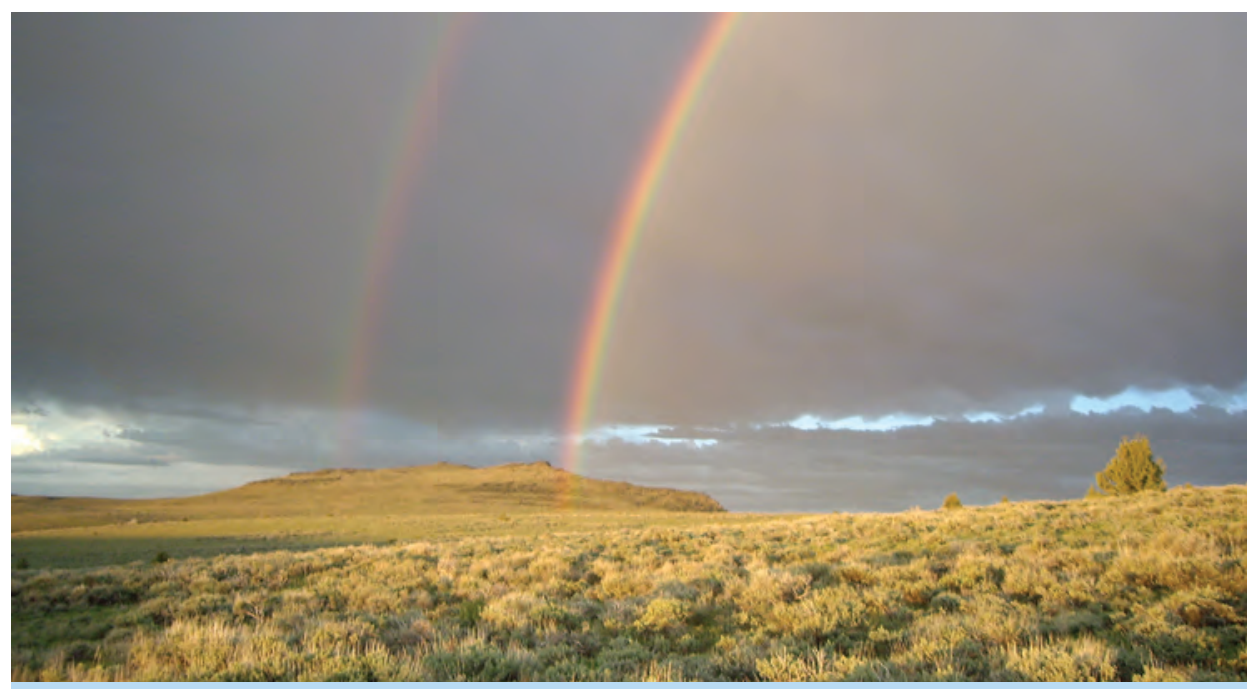

Rainbow on Steens Mountain in southeastern Oregon. Photograph by Steven Hanser, U.S. Geological Survey. 


\section{Response of Sagebrush Ecosystems to Precipitation Shifts}

Rangelands store approximately 30 percent of the world's terrestrial carbon, yet it is unclear how changes in precipitation associated with changing climate will influence carbon storage capacity in these dry ecosystems. To investigate how rangelands will respond to altered precipitation patterns, USGS and university researchers have been investigating how changes in the amount and timing of precipitation affect litter decomposition and soil carbon stabilization in plots that received supplemental precipitation in either winter or summer. These experiments were conducted over a 21-year period in plots dominated by native sagebrush and crested wheatgrass (Agropyron cristatum), an introduced species that has become invasive. Results may inform predictions of how carbon storage in rangeland communities will be affected by the interaction of altered precipitation and conversion of diverse native communities to exotic grasslands.

\section{Contact}

Matthew J. Germino, USGS Forest and Rangeland Ecosystem Science Center; mgermino@usgs.gov; 208-426-3353

\section{Publications}

Campos, X., Germino, M.J., and de Graaff, M.-A., 2017, Enhanced precipitation promotes decomposition and soil C stabilization in semiarid ecosystems, but seasonal timing of wetting matters: Plant and Soil, v. 416, nos. 1-2, p. 427-436, https://doi.org/10.1007/s11104-017-3221-1.

McAbee, K., Reinhardt, K., Germino, M.J., and Bosworth, A., 2017, Response of aboveground carbon balance to long-term, experimental enhancements in precipitation seasonality is contingent on plant community type in cold-desert rangelands: Oecologia, v. 183, no. 3, p. 861-874, https://doi.org/10.1007/s00442-017-3814-7.

Reinhardt, K., McAbee, K., and Germino, M.J., 2018, Changes in structure and physiological functioning due to experimentally enhanced precipitation seasonality in a widespread shrub species: Plant Ecology, First Online article posted June 7, 2018, 13 p., https://doi.org/10.1007/s11258-018-0845-z.

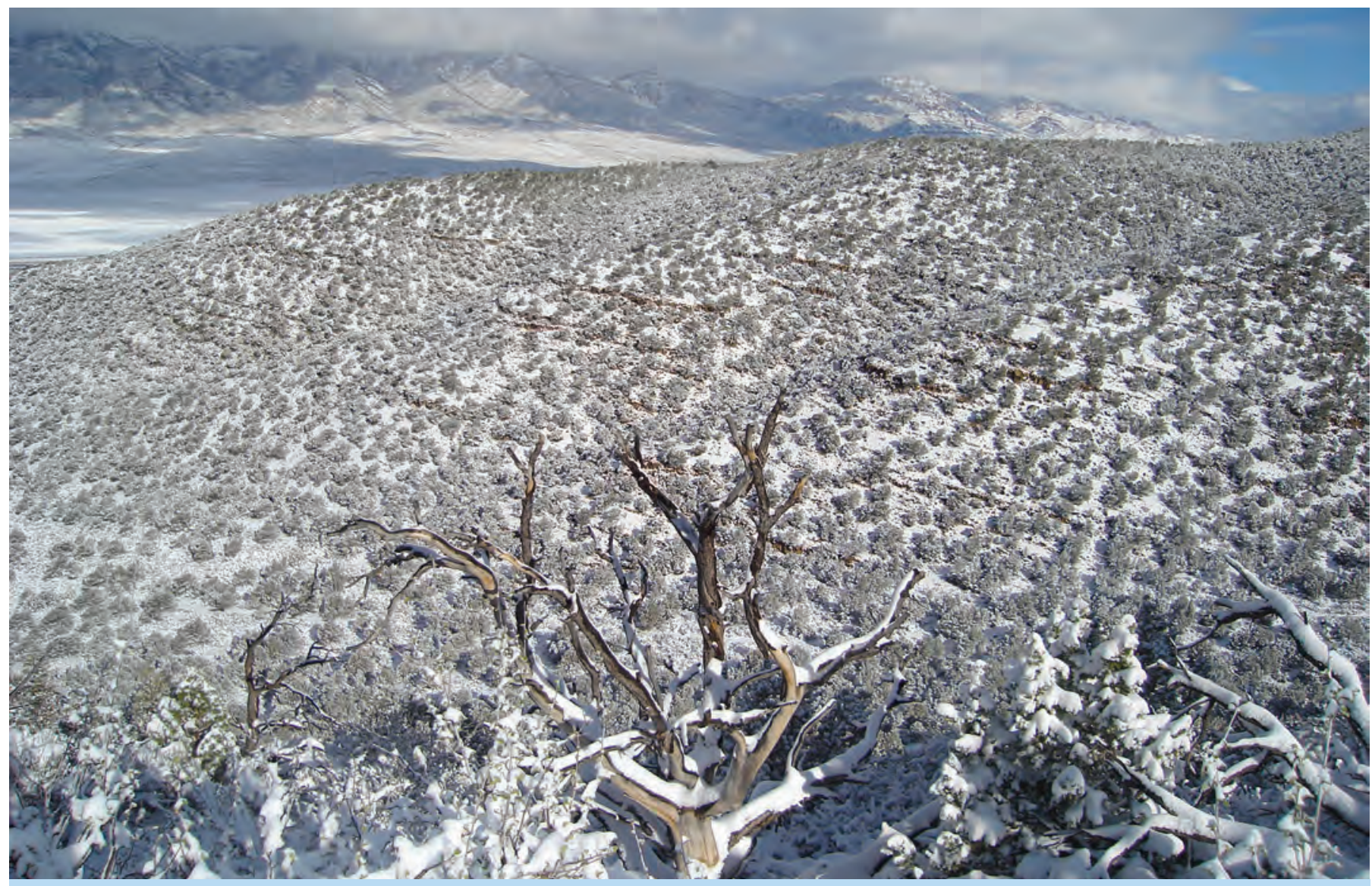

Late season snow in pinyon-juniper near Scipio, Utah. Photograph by Steven Hanser, U.S. Geological Survey. 


\section{Phenological Responses to Long-Term Environmental Drivers in the Northern Great Plains}

Ecological response of vegetation over relatively short time periods (months to years) is often influenced by the broader spatial and temporal context; therefore, longer term analyses are needed to understand site response within typically measured time periods. In order to inform rangeland monitoring efforts on BLM-managed lands across Montana, North Dakota, and South Dakota, USGS scientists are examining variability of phenology and productivity to (1) define the frequency and variability in climate patterns; (2) compare climate drivers of productivity including temperature, precipitation, and vapor pressure deficit; (3) improve the understanding of ecological memory in the response of key phenological measures to climate drivers; and (4) use these processes to develop models of current productivity and ecological site potential based climate and management scenarios. An understanding of these feedbacks and mechanisms will improve the assessment of management practices such as restoration, treatment, timing adjustments, and other actions employed to meet natural resource objectives.

\section{Contact}

David J.A. Wood, USGS Northern Rocky Mountain Science Center; dwood@usgs.gov; 406-896-5246

\section{Tracking Drought-Induced Variability in Sagebrush Ecosystem Productivity}

USGS scientists, in collaboration with WLCI partners, are investigating the recovery of sagebrush ecosystems after a recent, severe drought in the Upper Green River Basin, Wyoming. The scientists are using satellite data to characterize broad characteristics of growing season productivity and detect monthly anomalies associated with drought from a 17-year period (2000-16). They are investigating the timing and lags of seasonal temperature and moisture on vegetation condition and determining if reduction in productivity is mediated by local biophysical properties. Map products identify the extent and severity of the disturbance, and highlight areas for plant community assessment. This approach can be used to assess the status and trends of sagebrush ecosystems over broad spatial and temporal scales and assess the recovery of sagebrush ecosystems exposed to multiple stressors and disturbance such as drought, energy development and management treatment.

\section{Contacts}

Timothy J. Assal, USGS Fort Collins Science Center; assalt@usgs.gov; 970-226-9134

Patrick Anderson, USGS Fort Collins Science Center; andersonpj@usgs.gov; 970-226-9488

\section{Publication}

Assal, T.J., 2018, Standardized precipitation evaporation index for the Upper Green River Basin (1896-2017): U.S. Geological Survey data release, https://doi.org/10.5066/P9VLM7Z6.

\section{Sagebrush Ecosystem Research Funded by Climate Adaptation Science Centers}

The USGS manages the network of Climate Adaptation Science Centers that provide funding for several of the USGS-led projects listed in this document, as well as supporting research by external partners (universities, nongovernmental organizations, and so forth). Research funding provided to external partners is helping address a variety of climate related science needs with a focus on those identified in the "Integrated Rangeland Fire Management Strategy Actionable Science Plan" and related management-oriented science needs assessments. The North Central, Northwest, and Southwest Climate Adaptation Science Centers have and will continue to provide resources for supporting activities identified as high-priority needs by the major management entities. Additional information can be found at https://casc.usgs.gov/.

\section{Contacts}

Robin O'Malley, USGS North Central Climate Adaptation Science Center; romalley@usgs.gov; 571-294-0922

Nicole DeCrappeo, USGS Northwest Climate Adaptation Science Center; ndecrappeo@usgs.gov; 541-750-1021

Stephen T. Jackson, USGS Southwest Climate Adaptation Science Center; stjackson@usgs.gov; 520-670-5591 


\section{References Cited}

Carter, S.K., Manier, D.J., Arkle, R.S., Johnston, A.N., Phillips, S.L., Hanser, S.E., and Bowen, Z.H., 2018, Annotated bibliography of scientific research on greater sage-grouse published since January 2015: U.S. Geological Survey OpenFile Report 2018-1008, 183 p., https://doi.org/10.3133/ofr20181008. [Interactive, searchable version is available at https://apps.usgs.gov/gsgbib/index.php.]

Chambers, J.C., Beck, J.L., Bradford, J.B., Bybee, J., Campbell, S., Carlson, J., Christiansen, T.J., Clause, K.J., Collins, G., Crist, M.R., Dinkins, J.B., Doherty, K.E., Edwards, F., Espinosa, S., Griffin, K.A., Griffin, P., Haas, J.R., Hanser, S.E., Havlina, D.W., Henke, K.F., Hennig, J.D., Joyce, L.A., Kilkenny, F.M., Kulpa, S.M., Kurth, L.L., Maestas, J.D., Manning, M., Mayer, K.E., Mealor, B.A., McCarthy, C., Pellant, M., Perea, M.A., Prentice, K.L., Pyke, D.A., Wiechman, L.A., and Wuenschel, A., 2017, Science framework for conservation and restoration of the sagebrush biome-Linking the Department of the Interior's Integrated Rangeland Fire Management Strategy to long-term strategic conservation actions; Part 1. Science basis and applications: U.S. Department of Agriculture, Forest Service, Rocky Mountain Research Station, General Technical Report RMRS-GTR-360, 213 p. [Also available at https://www.treesearch.fs.fed.us/pubs/53983.]

Hanser, S.E., Leu, M., Knick, S.T., and Aldridge, C.L., eds., 2011, Sagebrush ecosystem conservation and managementEcoregional assessment tools and models for the Wyoming Basins: Lawrence, Kans., Allen Press, 409 p. [Also available at https://pubs.er.usgs.gov/publication/70118768.]

Integrated Rangeland Fire Management Strategy Actionable Science Plan Team, 2016, The Integrated Rangeland Fire Management Strategy Actionable Science Plan: Washington, D.C., U.S. Department of the Interior, 128 p. [Also available at http://integratedrangelandfiremanagementstrategy.org/wp-content/uploads/2016/10/IRFMS_Actionable_Science_Plan.pdf.]

Nauman, T.W., Duniway, M.C., Villarreal, M.L., and Poitras, T.B., 2017, Disturbance automated reference toolset (DART)Assessing patterns in ecological recovery from energy development on the Colorado Plateau: Science of the Total Environment, v. 584-585, p. 476-488, https://doi.org/10.1016/j.scitotenv.2017.01.034.

Young, S.M., 2017, U.S. Geological Survey shrub/grass products provide new approach to shrubland monitoring: U.S. Geological Survey Fact Sheet 2017-3084, 4 p., https://doi.org/10.3133/fs20173084.

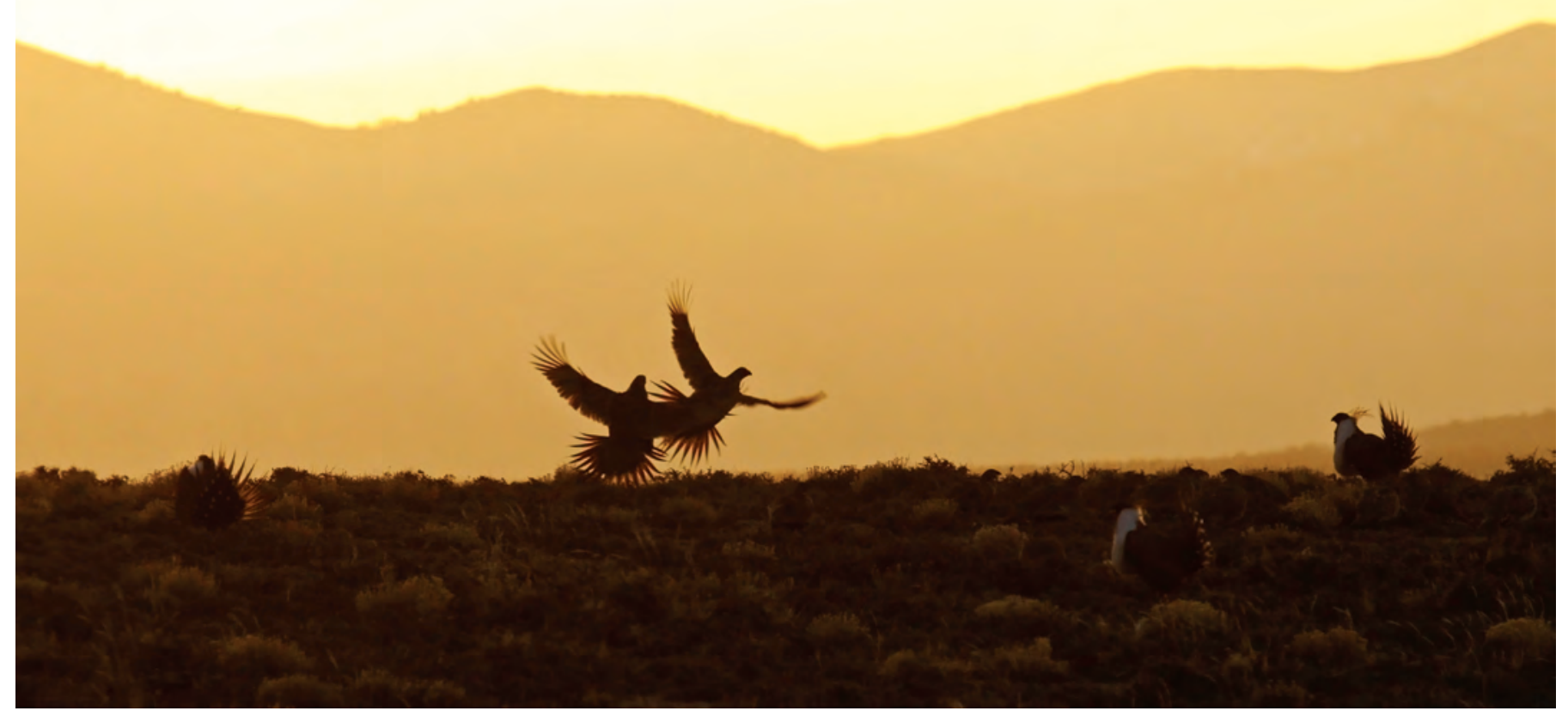

Sage-grouse on a lek at sunrise. Photograph by Tatiana Gettelman, U.S. Geological Survey. 


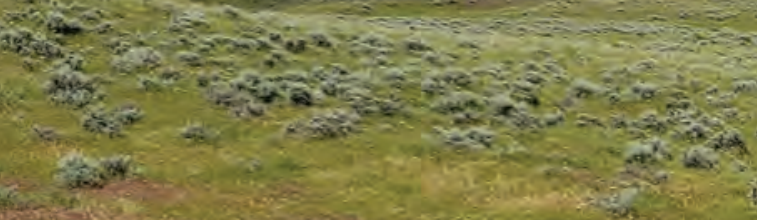

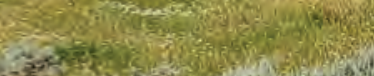

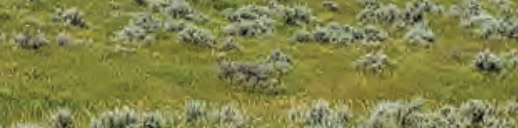

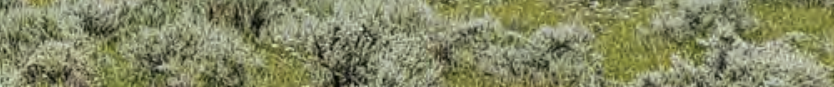

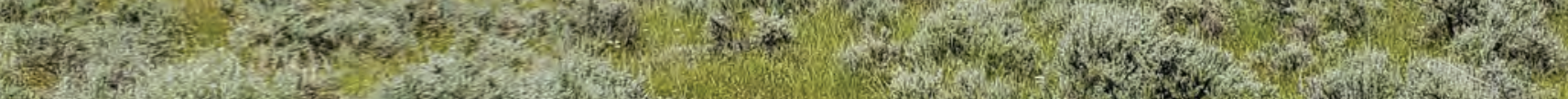

\section{H.

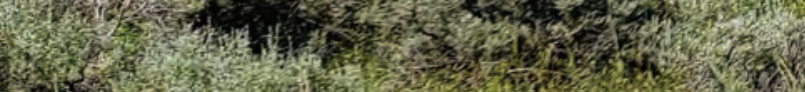

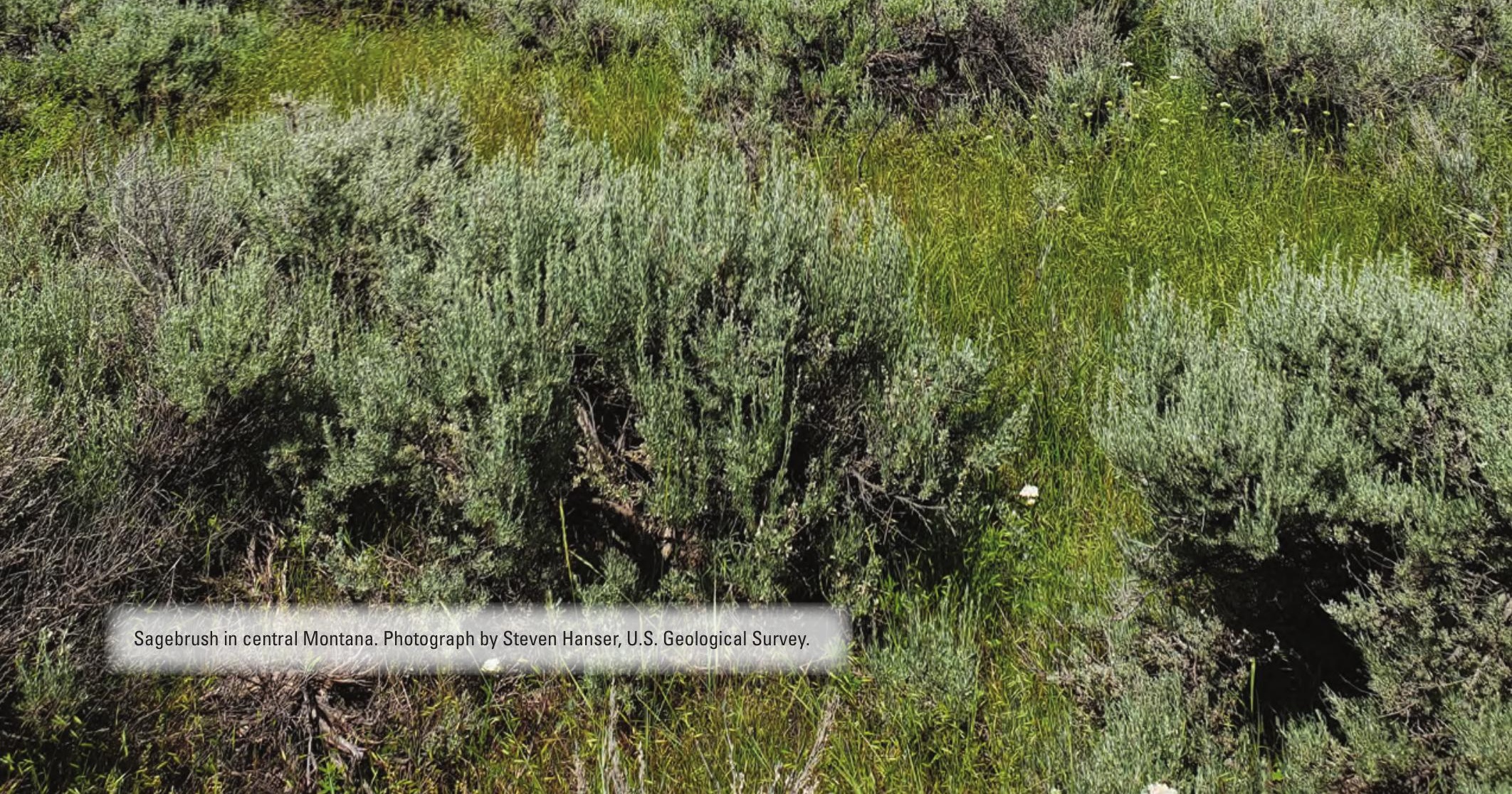

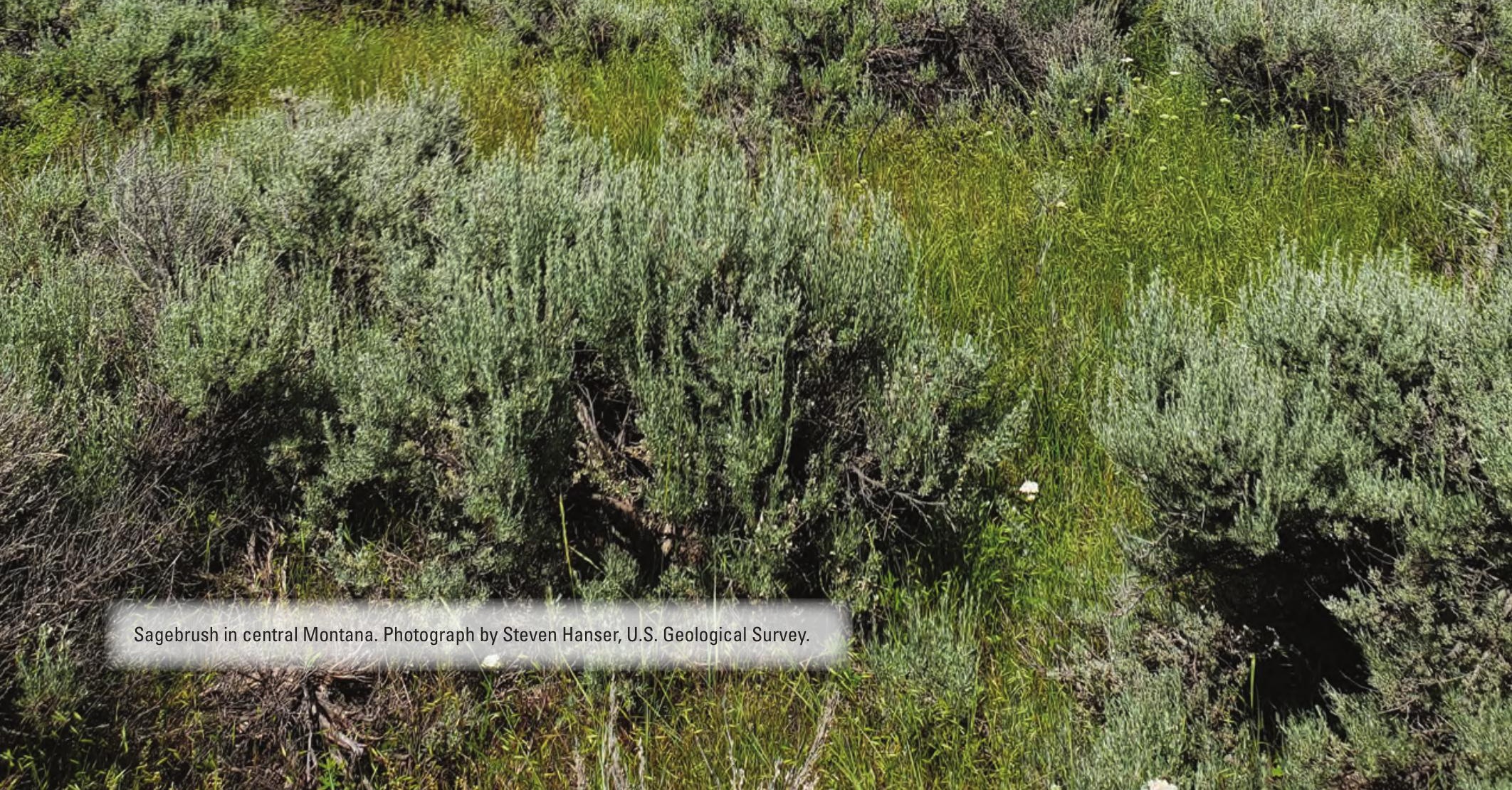


Manuscript was approved on August 16, 2018

Prepared by the USGS Science Publishing Network Reston and Rolla Publishing Service Centers Edited by Natalie Juda Layout by Suzanne C. Roberts

For additional information regarding this publication, please contact: Steven E. Hanser; shanser@usgs.gov

Or visit the Sage-Grouse and Sagebrush Ecosystem Program https://www.usgs.gov/ecosystems/sage-grouse-sagebrushecosystem 
$\sin x=$

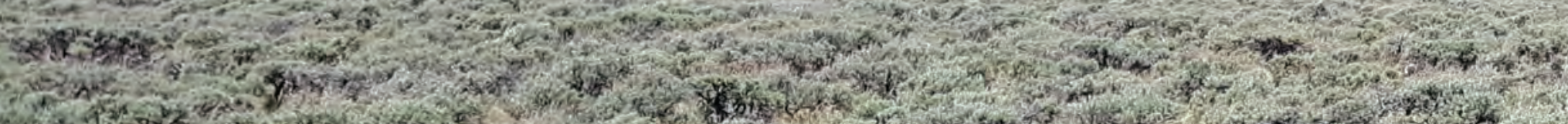

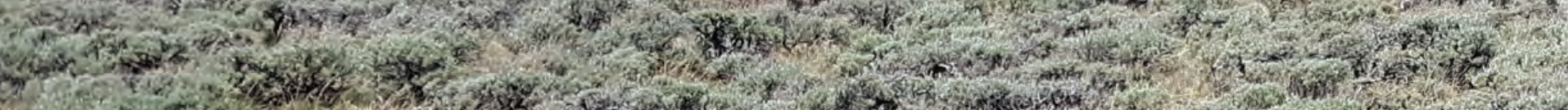

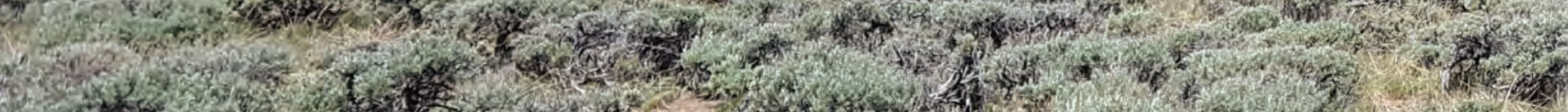
H.

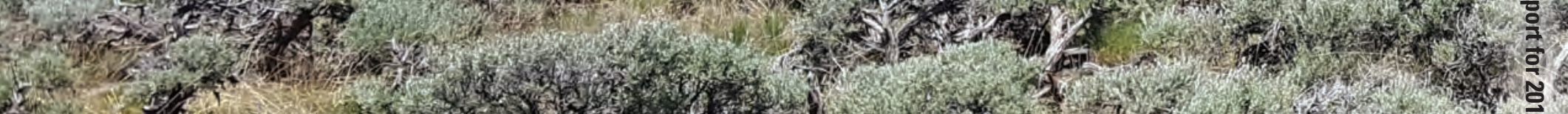

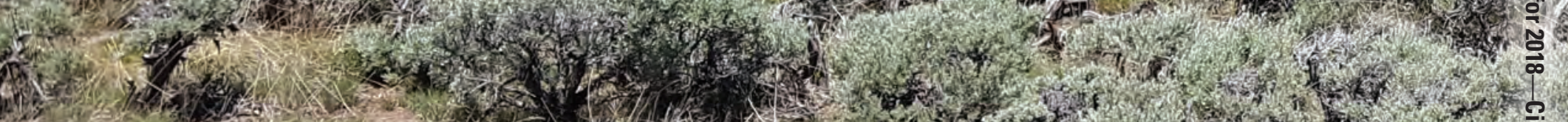

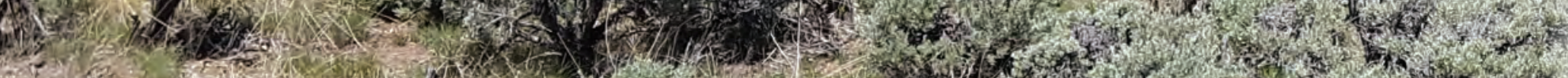

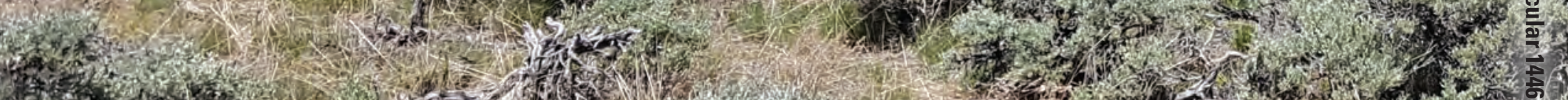
H.

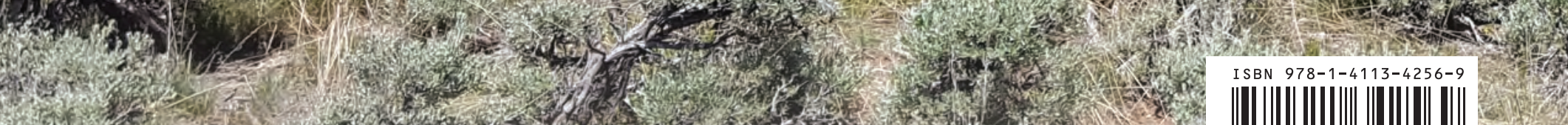
a

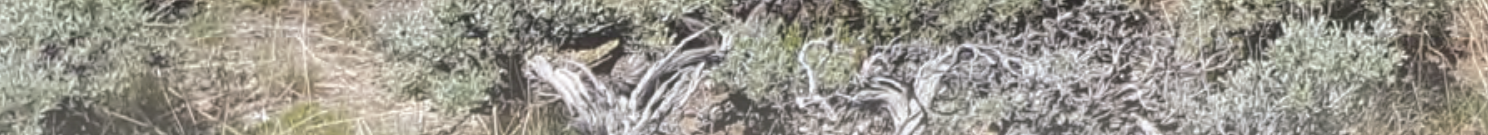

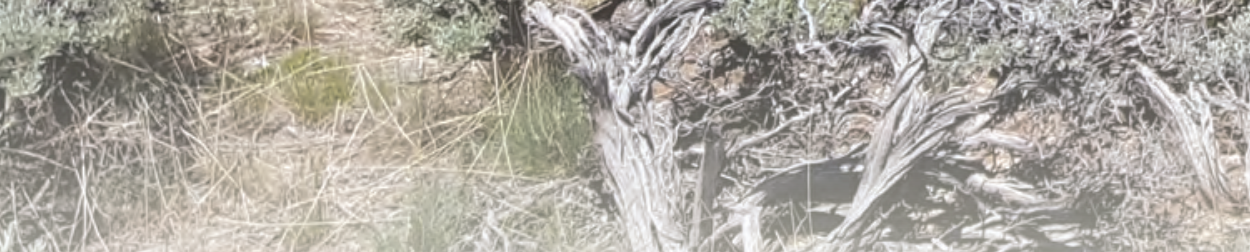

